\title{
Discovery and Optimization of Indolyl-Containing 4-Hydroxy-2- Pyridone Type II DNA Topoisomerase Inhibitors Active against Multidrug Resistant Gram-negative Bacteria
}

\author{
Aleksey I. Gerasyuto, Michael A. Arnold, * Jiashi Wang, Guangming Chen, Xiaoyan Zhang, Sean Smith, \\ Matthew G. Woll, John Baird, Nanjing Zhang, Neil G. Almstead, Jana Narasimhan, Srinivasa Peddi, \\ Melissa Dumble, Josephine Sheedy, Marla Weetall, Arthur A. Branstrom, J. V. N. Prasad, \\ and Gary M. Karp
}

PTC Therapeutics, Inc., 100 Corporate Court, South Plainfield, New Jersey 07080, United States

\section{Supporting Information}
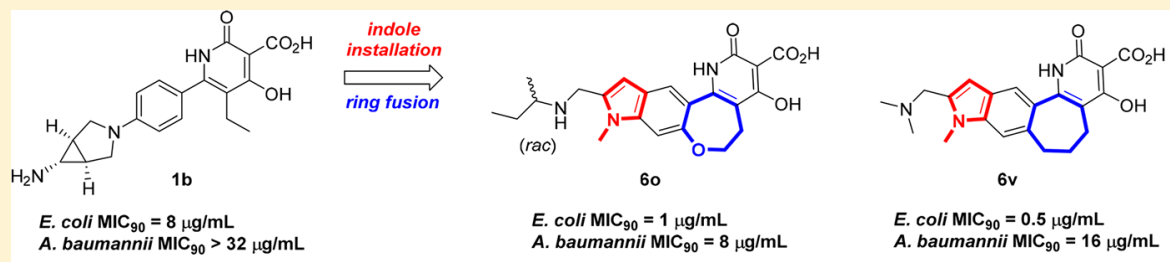

A. baumannii $\mathrm{MIC}_{90}=8 \mu \mathrm{g} / \mathrm{mL}$

E. coli $\mathrm{MIC}_{90}=0.5 \mu \mathrm{g} / \mathrm{mL}$ A. baumannii $\mathrm{MIC}_{90}=16 \mu \mathrm{g} / \mathrm{mL}$ For Table of Contents Only

ABSTRACT: There exists an urgent medical need to identify new chemical entities (NCEs) targeting multidrug resistant (MDR) bacterial infections, particularly those caused by Gram-negative pathogens. 4-Hydroxy-2-pyridones represent a novel class of nonfluoroquinolone inhibitors of bacterial type II topoisomerases active against MDR Gram-negative bacteria. Herein, we report on the discovery and structure-activity relationships of a series of fused indolyl-containing 4-hydroxy-2-pyridones with improved in vitro antibacterial activity against fluoroquinolone resistant strains. Compounds $\mathbf{6 o}$ and $\mathbf{6 v}$ are representative of this class, targeting both bacterial DNA gyrase and topoisomerase IV (Topo IV). In an abbreviated susceptibility screen, compounds 6o and $6 \mathbf{v}$ showed improved $\mathrm{MIC}_{90}$ values against Escherichia coli $(0.5-1 \mu \mathrm{g} / \mathrm{mL})$ and Acinetobacter baumannii $(8-16 \mu \mathrm{g} / \mathrm{mL})$ compared to the precursor compounds. In a murine septicemia model, both compounds showed complete protection in mice infected with a lethal dose of E. coli.

\section{INTRODUCTION}

Infections caused by drug resistant bacteria represent a major threat to human health. ${ }^{1}$ The Centers for Disease Control and Prevention (CDC) estimates that in the United States more than 2 million people acquire serious drug-resistant bacterial infections resulting in more than 23,000 deaths annually. ${ }^{2}$ The financial burden to the U.S. health system alone has been estimated at billions of dollars annually. ${ }^{3}$ Several initiatives, including the Infectious Diseases Society of America's " $10 \times$ '20 Initiative" 4 and several public-private partnerships of the Innovative Medicines Initiative (IMI), ${ }^{5}$ have been developed to combat this antimicrobial resistance threat. At the same time, there has been a large body of literature highlighting the challenges involved in identifying novel antibacterial agents. ${ }^{6}$ Despite the urgent clinical need for new chemical entities (NCEs) to treat these serious infections, there has been a significant decline in the number of new antibacterial agents developed and approved over the past three decades. ${ }^{6 c, 7}$ For NCEs that target infections caused by Gram-negative pathogens, this problem is particularly acute. ${ }^{4}$ Despite these challenges, there remains a significant need for novel antibacterial agents that target these drug resistant pathogens.

Fluoroquinolones are a major class of broad spectrum antibacterial agents that target the type II bacterial DNA topoisomerases, DNA gyrase and topoisomerase IV (Topo IV). ${ }^{8}$ The function of DNA gyrase and Topo IV is to maintain DNA in a proper topological state during DNA replication and transcription. ${ }^{9}$ Several additional classes of type II bacterial DNA topoisomerase inhibitors have been reported, including 3aminoquinazolinediones, ${ }^{10} 4 \mathrm{H}$-4-oxoquinolizines, ${ }^{8 \mathrm{e}, 11}$ isothiazolones, ${ }^{12}$ quinolyl-piperidines, ${ }^{13}$ and spiropyrimidinetriones. ${ }^{14}$

Recently, we disclosed a novel series of 4-hydroxy-2pyridones, e.g., $\mathbf{1 a}$ and $\mathbf{1 b}$, that target type II bacterial DNA topoisomerases and are active against wild-type and resistant Gram-negative pathogens (Figure 1). ${ }^{15}$ These compounds were derived from a series of structurally related bacterial protein synthesis inhibitors ${ }^{16}$ by removal of a benzyl substituent from the 2-pyridone nitrogen atom. Compound $\mathbf{1 b}$ had modest in vitro antibacterial activity and demonstrated efficacy in a murine septicemia model. ${ }^{15}$ Against an abbreviated panel of E. coli strains, the $\mathrm{MIC}_{90}$, defined as the lowest concentration inhibiting $90 \%$ of the isolates, was $8 \mu \mathrm{g} / \mathrm{mL}$.

To expand the chemical space and explore novel scaffolds with improved antibacterial activity and pharmaceutical properties, we initially envisioned modifying the substituted aniline

Received: January 22, 2018

Published: May 4, 2018 
<smiles>[R20]Nc1ccc(-c2[nH]c(=O)c(C(=O)O)c(O)c2CC)cc1</smiles>

1a $\quad \mathrm{NR}_{\mathrm{a}} \mathrm{R}_{\mathrm{b}}={ }_{\mathrm{N}}^{-\mathrm{N}^{-} \mathrm{z}}$

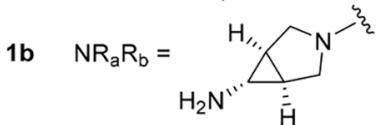<smiles>[R3]c1c(-c2ccc3c(c2)c([R])c([R])n3C)[nH]c(=O)c(C(=O)O)c1O</smiles>

2<smiles>[R7]c1cc2cc3c(cc2n1C)CCCc1c-3[nH]c(=O)c(C(=O)O)c1O</smiles>

Figure 1. Structures of novel 4-hydroxy-2-pyridone bacterial topoisomerase II inhibitors.

Scheme $1^{a}$<smiles>[R]c1c([R])n(C)c2ccc(Br)cc12</smiles><smiles>[R]c1c([R])n(C)c2ccc(C(=O)CCC)cc12</smiles><smiles>[R]c1c([R])n(C)c2ccc(-c3[nH]c(=O)c(C(C)=O)c(O)c3CC)cc12</smiles><smiles>[CH][CH]</smiles>

$$
\begin{array}{ll}
\text { 9a } & \mathrm{R}_{1}=H ; \mathrm{R}_{2}=H \\
\text { 9b } & \mathrm{R}_{1}=M e ; R_{2}=H \\
\text { 9c } & \mathrm{R}_{1}=M e ; R_{2}=M e
\end{array}
$$<smiles>[R]c1c([R])n(C)c2ccc(-c3[nH]c(=O)c(C(=O)O)c(O)c3CC)cc12</smiles>

2a $\quad \mathrm{R}_{1}=\mathrm{H} ; \mathrm{R}_{2}=\mathrm{H}$

2b $\quad \mathrm{R}_{1}=\mathrm{Me} ; \mathrm{R}_{2}=\mathrm{H}$

2c $\mathrm{R}_{1}=\mathrm{Me} ; \mathrm{R}_{2}=\mathrm{Me}$

${ }^{a}$ Reagents and conditions: (a) $n$ - $\mathrm{BuLi}$ (1.2 equiv), THF, $-78{ }^{\circ} \mathrm{C}$, then $\mathrm{N}$-methoxy- $N$-methylbutyramide ( 1.2 equiv), $\mathrm{THF},-78{ }^{\circ} \mathrm{C}$ to rt, $50-75 \%$; (b) $t$-butylamine (4 equiv), $\mathrm{TiCl}_{4}$ (0.65 equiv), $\mathrm{CH}_{2} \mathrm{Cl}_{2}, 0^{\circ} \mathrm{C}$ to rt, overnight; (c) $\mathrm{CH}\left(\mathrm{CO}_{2} \mathrm{Me}\right)_{3}\left(1.7\right.$ equiv), $\mathrm{Ph}_{2} \mathrm{O}, 230{ }^{\circ} \mathrm{C}, 10 \mathrm{~min}, 21-56 \%$ over 2 steps; (d) LiI (3.0 equiv), EtOAc, $65^{\circ} \mathrm{C}, 1 \mathrm{~h}, 54-67 \%$.

Scheme $2^{a}$
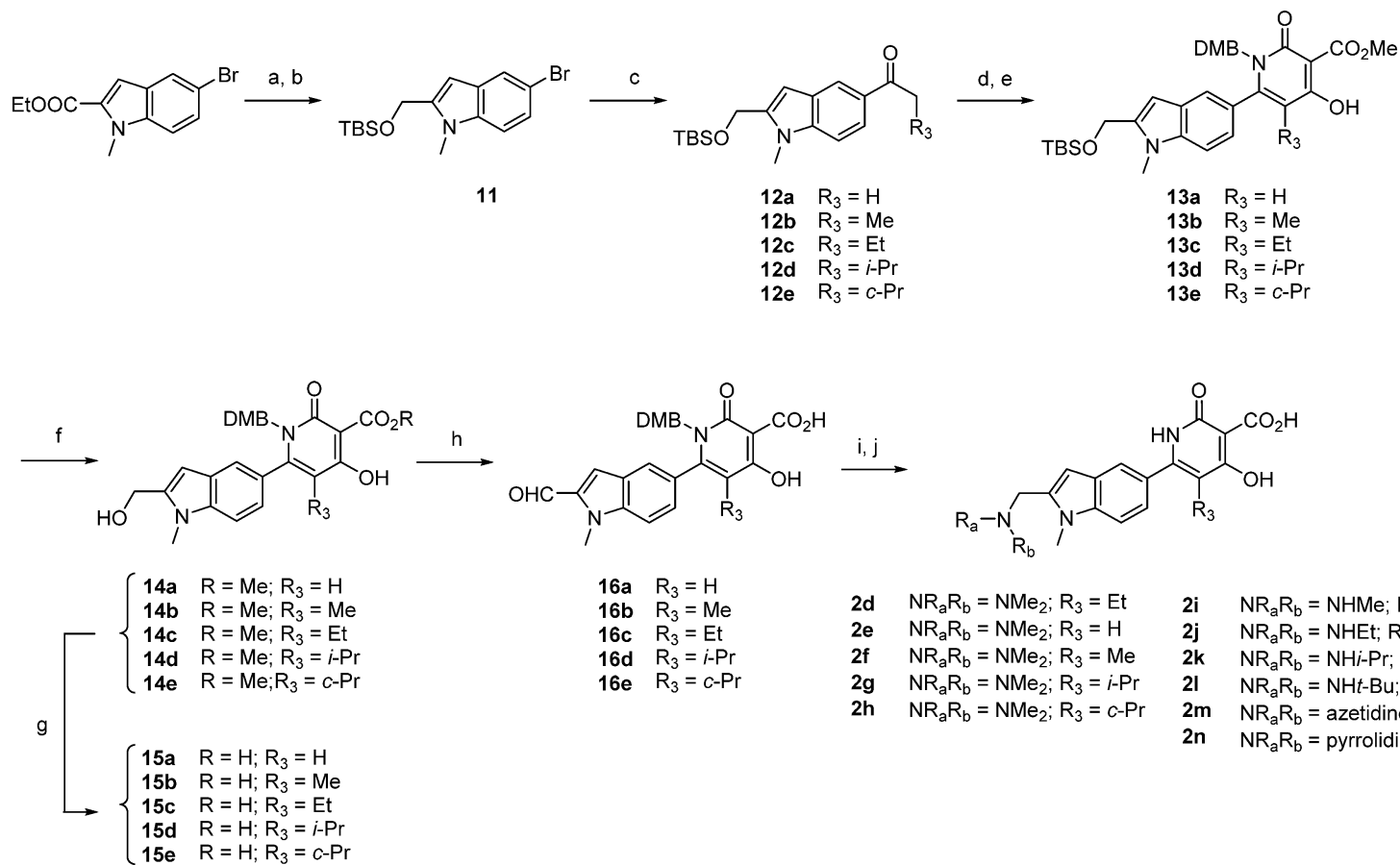

16a $\quad \mathrm{R}_{3}=\mathrm{H}$

$16 \mathrm{~b} \quad \mathrm{R}_{3}=\mathrm{Me}$

$16 \mathrm{c} \mathrm{R}_{3}=i-\mathrm{Pr}$

16e $\quad \mathrm{R}_{3}=c-\mathrm{P}$

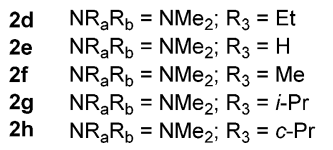
2i $\quad \mathrm{NR}_{\mathrm{a}} \mathrm{R}_{\mathrm{b}}=\mathrm{NHMe} ; \mathrm{R}_{3}=\mathrm{Et}$ $\mathrm{NR}_{\mathrm{a}} \mathrm{R}_{\mathrm{b}}=\mathrm{NHEt} ; \mathrm{R}_{3}=\mathrm{Et}$ $2 \mathrm{k} \quad \mathrm{NR}_{\mathrm{a}} \mathrm{R}_{\mathrm{b}}=\mathrm{NH}$ i-Pr; $\mathrm{R}_{3}=\mathrm{Et}$ 2I $\quad \mathrm{NR}_{\mathrm{a}} \mathrm{R}_{\mathrm{b}}=\mathrm{NH} t-\mathrm{Bu} ; \mathrm{R}_{3}=\mathrm{Et}$ $2 \mathrm{~m} \quad \mathrm{NR}_{\mathrm{a}} \mathrm{R}_{\mathrm{b}}=$ azetidine; $\mathrm{R}_{3}=\mathrm{Et}$ 2n $\quad N R_{a} R_{b}=$ pyrrolidine; $R_{3}=E t$

${ }^{a}$ Reagents and conditions: (a) DIBAL-H (2.2 equiv), $-78{ }^{\circ} \mathrm{C}$ to rt, $\mathrm{CH}_{2} \mathrm{Cl}_{2}$; (b) TBSCl (1.3 equiv), imidazole ( 1.3 equiv), $\mathrm{CH}_{2} \mathrm{Cl}_{2}, 0^{\circ} \mathrm{C}, 96 \%$ over 2 steps; (c) $n$ - $\mathrm{BuLi}$ (1.2 equiv), THF, $-78{ }^{\circ} \mathrm{C}$, followed by Weinreb amides (1.2 equiv), THF, $-78{ }^{\circ} \mathrm{C}$ to $\mathrm{rt}, 57-92 \%$; (d) 2,4 dimethoxybenzylamine (1.1 equiv), $\mathrm{TiCl}_{4}$ (0.65 equiv), $\mathrm{Et}_{3} \mathrm{~N}$ (2.7 equiv), $\mathrm{CH}_{2} \mathrm{Cl}_{2}, 0{ }^{\circ} \mathrm{C}$ to rt; (e) $\mathrm{CH}\left(\mathrm{CO}_{2} \mathrm{Me}\right)_{3}$ (1.7 equiv), diphenyl ether, $230{ }^{\circ} \mathrm{C}$, $10 \mathrm{~min}, 37-56 \%$ over 2 steps; (f) TBAF (2.0 equiv), THF, $0{ }^{\circ} \mathrm{C}$ to rt, $70-92 \%$; (g) LiI (3.0 equiv), EtOAc, $65{ }^{\circ} \mathrm{C}, 1 \mathrm{~h}, 74-99 \%$; $(\mathrm{h}) \mathrm{MnO} 2(20$ equiv), $\mathrm{CH}_{2} \mathrm{Cl}_{2}, \mathrm{rt}, 1 \mathrm{~h}, 64-85 \%$; (i) amine (2 equiv), $\mathrm{AcOH}$ (2 equiv), DCE, rt, $1 \mathrm{~h}$, then $\mathrm{NaBH}(\mathrm{OAc}){ }_{3}\left(2\right.$ equiv); (j) TIPS-H, TFA, $65{ }^{\circ} \mathrm{C}, 1 \mathrm{~h}$ $\mathrm{HCl}, 12-57 \%$ yield over 2 steps. 
Scheme $3^{a}$

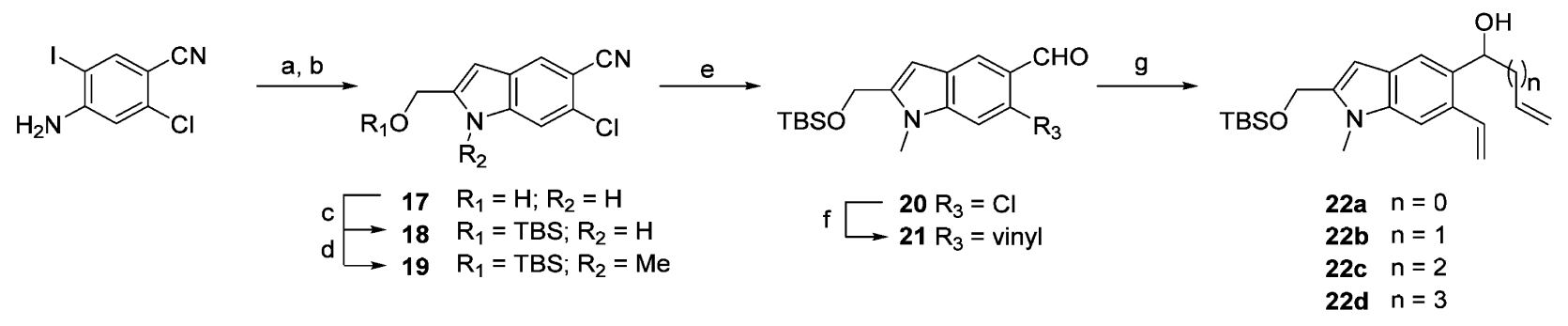

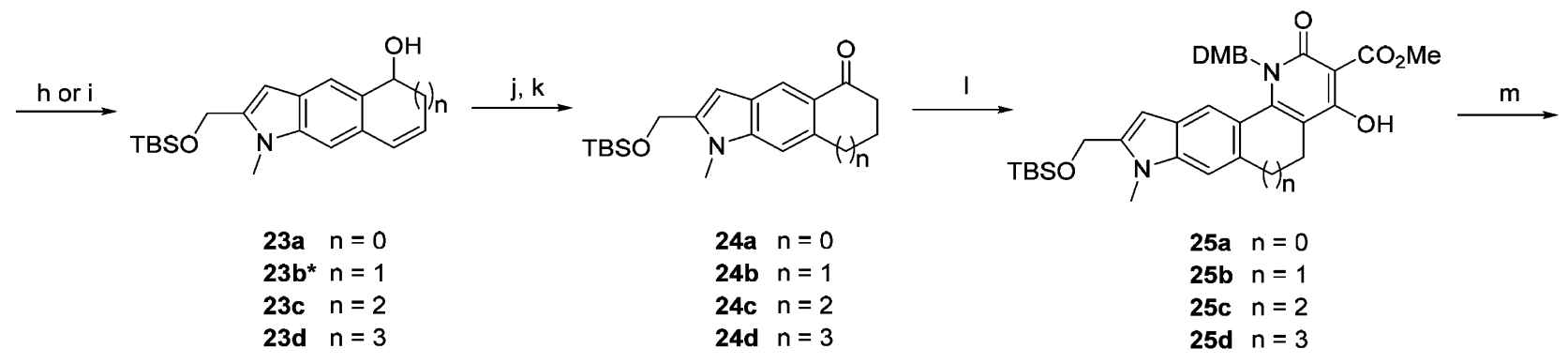

*Not isolated

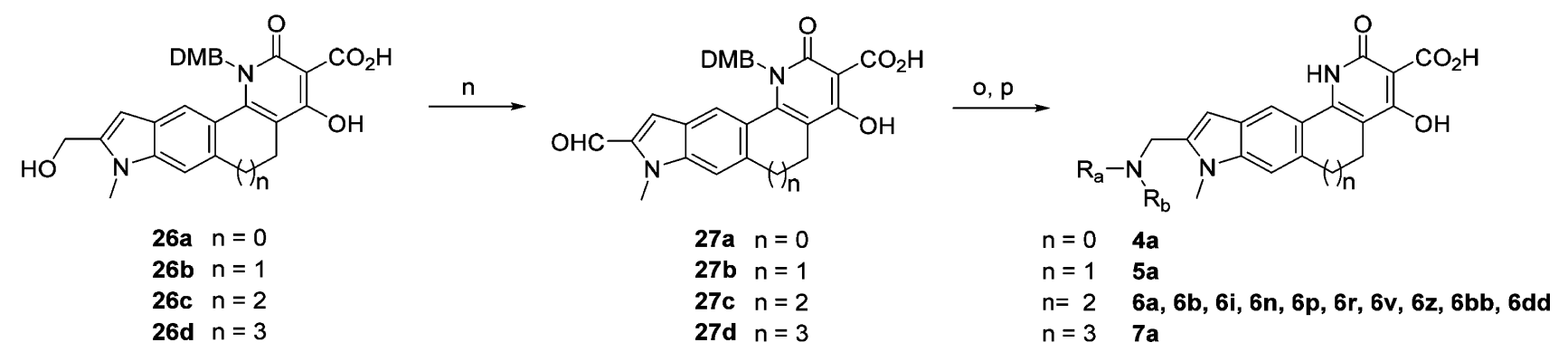

${ }^{a}$ Reagents and conditions: (a) propargyl alcohol (1.2 equiv), $\mathrm{Et}_{3} \mathrm{~N}$ (2 equiv), $\mathrm{Pd}\left(\mathrm{PPh}_{3}\right)_{2} \mathrm{Cl}_{2}(1 \mathrm{~mol} \%), \mathrm{CuI}(2 \mathrm{~mol} \%), \mathrm{CH}{ }_{3} \mathrm{CN}, 70{ }^{\circ} \mathrm{C}, 2 \mathrm{~h}$; $(\mathrm{b}) t$ BuOK (2.2 equiv), DMF, $70{ }^{\circ} \mathrm{C}, 2 \mathrm{~h}, 77 \%$ over 2 steps; (c) TBSCl (1.2 equiv), imidazole (1.3 equiv), DMF, rt, $1.5 \mathrm{~h}, 74 \%$; (d) $60 \% \mathrm{NaH}$ dispersion (1.4 equiv), $0{ }^{\circ} \mathrm{C}$ to rt, $10 \mathrm{~min}$, then $\mathrm{MeI}\left(1.4\right.$ equiv), $0{ }^{\circ} \mathrm{C}$ to rt, $1.5 \mathrm{~h}, 76 \%$; (e) DIBAL-H (1.2 equiv), $\mathrm{CH}_{2} \mathrm{Cl}_{2},-78{ }^{\circ} \mathrm{C}$ to $-15{ }^{\circ} \mathrm{C}$, then Rochelle salt, $-40{ }^{\circ} \mathrm{C}$ to $\mathrm{rt}, 1 \mathrm{~h}, 91 \%$; (f) potassium vinyltrifluoroborate (1.5 equiv), $\mathrm{Pd}(\mathrm{OAc})_{2}(3 \mathrm{~mol} \%)$, S-Phos ligand $(6 \mathrm{~mol} \%), \mathrm{K}_{2} \mathrm{CO}_{3}(3$ equiv), dioxane $/ \mathrm{H}_{2} \mathrm{O}, 90^{\circ} \mathrm{C}, 5 \mathrm{~h}, 89 \%$; $(\mathrm{g})$ 1-propenylmagnesium chloride $(n=0)$, or allymagnesium chloride $(n=1)$, or 3-butenylmagnesium bromide $(n$ $=2$ ), or 4-pentenylmagnesium bromide $(n=3)$, THF, $-78{ }^{\circ} \mathrm{C}$ to $\mathrm{rt}, 90-100 \%$; (h) Grubbs second generation catalyst $(3-5 \mathrm{~mol} \%)$, toluene, $12-24$ h; (i) TBSCl (2.1 equiv), imidazole (2.5 equiv), $\mathrm{CH}_{2} \mathrm{Cl}_{2}$, rt, overnight, $76 \%$, then Grubbs second generation catalyst $(3 \mathrm{~mol} \%)$, toluene, $2 \mathrm{~h}$, then TBAF (2.1 equiv), THF, $96 \mathrm{~h}, 20 \%$, then TBSCl (1.1 equiv), imidazole (1.2 equiv), THF, $0{ }^{\circ} \mathrm{C}$ to rt, $1.5 \mathrm{~h}, 77 \%$; $(\mathrm{j}) 10 \% \mathrm{Pd}-\mathrm{C}(n=0$ or $2-3), \mathrm{H}_{2}$, $1 \mathrm{~atm}$, EtOAc $\mathrm{CH}_{2} \mathrm{Cl}_{2}, \mathrm{rt}, 3 \mathrm{~h}$ or $10 \% \mathrm{PtO}_{2}(n=1)$, toluene; (k) NMO, TPAP $(n=0$ or $2-3), 4 \AA \mathrm{CH}_{2} \mathrm{Cl}_{2}, 0{ }^{\circ} \mathrm{C}$ to rt or $\mathrm{MnO}_{2}(n=1), \mathrm{CH}_{2} \mathrm{Cl}_{2} ;(\mathrm{l})$ 2,4-dimethoxybenzyl amine (1.05 equiv), $\mathrm{Et}_{3} \mathrm{~N}$, (2.7 equiv), $\mathrm{TiCl}_{4}$ (0.65 equiv), $\mathrm{CH}_{2} \mathrm{Cl}_{2}, 0^{\circ} \mathrm{C}$ to rt, $16 \mathrm{~h}$, then $\left.\mathrm{CH}^{\circ} \mathrm{CO}_{2} \mathrm{Me}\right)_{3}(1.7$ equiv), diphenyl ether, $230{ }^{\circ} \mathrm{C}, 10 \mathrm{~min}, 33-63 \%$ over 2 steps; (m) TBAF (2.5 equiv), THF, rt, $2 \mathrm{~h}$, then LiI ( 2.9 equiv), EtOAc, $60{ }^{\circ} \mathrm{C}, 1.5 \mathrm{~h}, 84-91 \%$ over 2 steps; (n) $\mathrm{MnO}_{2}$ (15 equiv), $\mathrm{CH}_{2} \mathrm{Cl}_{2}$ rt, 69-82\%; (o) amine (2.0 equiv), $\mathrm{AcOH}$ (2.0 equiv), DCE, rt, 1 h, then $\mathrm{NaBH}(\mathrm{OAc})_{3}(2.0$ equiv), 2 h; (p) TIPS$\mathrm{H}$, TFA, $60^{\circ} \mathrm{C}, 2 \mathrm{~h}$, then $\mathrm{HCl}, 6-83 \%$ over 2 steps.

moiety in 1a by cyclizing the methyl substituent onto the aryl ring attached to the 4-hydroxy-2-pyridone moiety to form an indole, e.g., 2. The resultant 5-indolyl-4-hydroxy-2-pyridones 2 retained a similar level and spectrum of antibacterial activity. The 5-indolyl-4-hydroxy-2-pyridones can exist in multiple conformation states by virtue of the rotational freedom around the bond connecting the indole and 2-pyridone rings. To determine whether restricting the rotational freedom could lead to analogues with improved antibacterial activity, we designed and evaluated a set of compounds, 3, containing a tether between the indole and 2-pyridone rings serving as a second attachment point. ${ }^{17}$ This allowed us to evaluate the effect of regioisomers, tether length, and constituents of the tether on the antibacterial activity and pharmaceutical properties.
Herein, we report on the discovery and evaluation of novel conformationally restricted analogues 3 that have improved minimum inhibitory concentrations (MICs) and spectrum of antibacterial activity against Gram-negative strains, and demonstrate efficacy in a murine septicemia model.

\section{RESULTS AND DISCUSSION}

Chemistry. The general synthetic route to 5-indolyl-4hydroxy-2-pyridones $\mathbf{2 a - 2} \mathbf{c}$ is outlined in Scheme 1. 5Bromoindoles were converted to ketones 9 by metal-halogen exchange followed by reaction with $N$-methoxy- $N$-methylbutyramide. Transformation of ketones 9 to the 5-indolyl-4-hydroxy2-pyridones $2 \mathrm{a}-\mathrm{c}$ was carried out by conversion of 9 to the respective $t$-butyl imines followed by high temperature annulation with trimethylmethanetricarboxylate to provide the 


\section{Scheme $4^{a}$}<smiles></smiles>

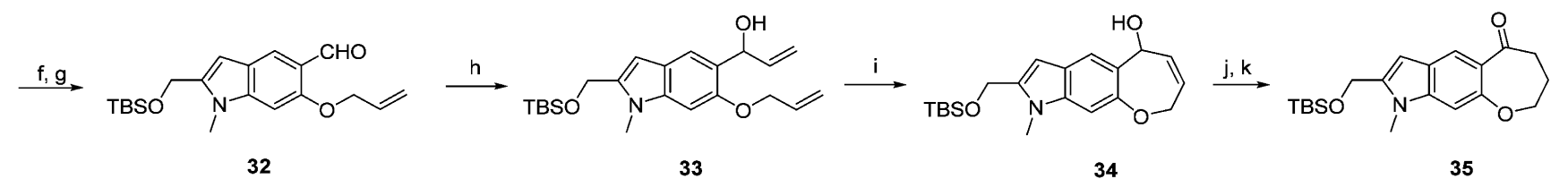<smiles>[R]C(=O)c1c(O)c2c(n(C(C)C)c1=O)-c1cc3cc(CO)n(C)c3cc1OCC2</smiles>

${ }^{a}$ Reagents and conditions: (a) allyl bromide (1.05 equiv), $\mathrm{K}_{2} \mathrm{CO}_{3}$ (1.1 equiv), DMF, rt, $16 \mathrm{~h}, 93 \%$; (b) ethyl azidoacetate ( 3 equiv), NaOEt ( 3.0 equiv), EtOH, $-10{ }^{\circ} \mathrm{C}$ to rt, $16 \mathrm{~h}, 62 \%$; (c) xylenes, $140{ }^{\circ} \mathrm{C}, 1 \mathrm{~h}, 47 \%$; (d) NaH (1.1 equiv), MeI (1.1 equiv), DMF, $0{ }^{\circ} \mathrm{C}$ to rt, $1 \mathrm{~h}, 92 \%$; (e) DIBAL-

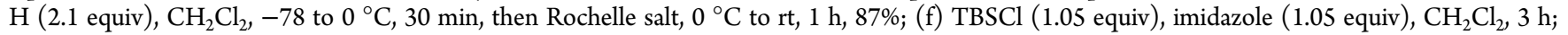
(g) $n$-BuLi (1.5 equiv), THF, $-78{ }^{\circ} \mathrm{C}, 30 \mathrm{~min}$, then DMF, $-78{ }^{\circ} \mathrm{C}$ to $\mathrm{rt}, 81 \%$ over 2 steps; (h) vinylmagnesium bromide (1.15 equiv), THF, $0{ }^{\circ} \mathrm{C}$ to rt, 1 h, 98\%; (i) Grubbs second generation catalyst, toluene, $60{ }^{\circ} \mathrm{C}, 3 \mathrm{~h}, 51 \%$; (j) $\mathrm{MnO}_{2}$ (7 equiv in three portions over $2 \mathrm{~h}$ ), $\mathrm{CH}_{2} \mathrm{Cl}_{2}, \mathrm{rt}$; $(\mathrm{k}) \mathrm{H}_{2}$, $\mathrm{PtO}_{2}, \mathrm{EtOH}, \mathrm{rt}, 3 \mathrm{~h}, 71 \%$ over 2 steps; (l) 2,4-dimethoxybenzyl amine (1.1 equiv), $\mathrm{Et}_{3} \mathrm{~N}$, (3.0 equiv), $\mathrm{TiCl}_{4}\left(0.6\right.$ equiv), $\mathrm{CH}_{2} \mathrm{Cl}_{2}, 0{ }^{\circ} \mathrm{C}$ to rt, 16 h; (m) trimethylmethanetricarboxylate (2.0 equiv), diphenyl ether, $230{ }^{\circ} \mathrm{C}, 15 \mathrm{~min} ; 43 \%$ over 2 steps; (n) TBAF (2.1 equiv), THF, rt, $1.5 \mathrm{~h}, 80 \%$; (o) LiI (3 equiv), EtOAc, $60{ }^{\circ} \mathrm{C}, 3 \mathrm{~h}, 98 \%$; (p) $\mathrm{MnO}_{2}$ (16 equiv in three portions over $2 \mathrm{~h}$ ), $\mathrm{CH}_{2} \mathrm{Cl}_{2}, 64 \%$; (q) amine (2.0 equiv), AcOH (2.0 equiv), $\mathrm{DCE}, \mathrm{rt}, 1 \mathrm{~h}$, then $\mathrm{NaBH}(\mathrm{OAc})_{3}\left(2.0\right.$ equiv), $2 \mathrm{~h}$; (r) TIPS-H, TFA, $60{ }^{\circ} \mathrm{C}, 1 \mathrm{~h}$, then $\mathrm{HCl} / \mathrm{Et}_{2} \mathrm{O}, 17-72 \%$ over 2 steps.

4-hydroxy-2-pyridone esters 10. Final targets $2 \mathrm{a}-\mathrm{c}$ were obtained by ester dealkylation.

An alternative route, depicted in Scheme 2, was utilized for the preparation of 5-indolyl-4-hydroxy-2-pyridones 2d-2n containing basic amines attached to the indole C-2 through a methylene spacer. Starting with ethyl 5-bromo-1-methyl- $1 \mathrm{H}$ indole-2-carboxylate, DIBAL-H reduction of the ester and protection of the resultant primary alcohol with TBSCl gave $\mathbf{1 1}$. Conversion of 11 to the ketone intermediates 12 was accomplished via metal-halogen exchange of the indole 5-Br, followed by reaction of the 5 -indolyllithium species with Weinreb amides. Transformation to the 5-indolyl-4-hydroxy-2pyridones 13 was carried out by initial conversion of the ketone to the 2,4-DMB imine followed by high temperature annulation of the imine with trimethylmethanetricarboxylate. TBS deprotection to the alcohols $\mathbf{1 4}$ followed by LiI-mediated ester dealkylation gave the hydroxy acid intermediates $\mathbf{1 5}$. Alcohol oxidation provided the indole-2-carboxaldehydes $\mathbf{1 6}$. Final targets $\mathbf{2 d}-\mathbf{n}$ were obtained by reductive amination followed by TFA-mediated DMB deprotection.

Several synthetic routes were developed to access basic amine-containing tetracyclic 4-hydroxy-2-pyridones 3. For maximum structural diversity and to evaluate analogues containing different tether lengths and/or heteroatoms in the tether between the indole and 2-pyridone rings, we envisioned utilizing cyclic ketones for the high temperature annulation analogously to that described previously to provide the tetracyclic 4-hydroxy-2-pyridones. Cyclic ketones of various ring sizes were readily prepared by olefin metathesis.

To prepare tetracyclic derivatives bearing an all carbon tether (forming 5-8-membered rings), we utilized a multistep synthetic sequence to arrive at the TBS-protected indolyl cyclic ketone intermediates $\mathbf{2 4 a - d}$ (Scheme 3). 4-Amino-2chloro-5-iodobenzonitrile ${ }^{18}$ was converted to the indole derivative $\mathbf{1 7}$ in two steps. ${ }^{19}$ TBS protection of the primary alcohol followed by $\mathrm{N}$-methylation of the indole $\mathrm{NH}$ and DIBAL-H reduction of the nitrile gave 20. Dienes 22a-d, precursors to the olefin metathesis, were obtained by SuzukiMiyaura $^{20}$ cross-coupling to give the 6-vinylindole 21, followed by reaction with alkenylmagnesium halides to give $\mathbf{2 2 a - d}$. Ring closing olefin metathesis ${ }^{21}$ using Grubbs second generation catalyst $^{22}$ provided the alkene-alcohols $23 a-d$. The key cyclic ketone intermediates were obtained by reduction of the ring double bond followed by oxidation of the secondary alcohol to provide the cyclic ketone intermediates $24 a-d$. Conversion of the cyclic ketones to the 2,4-DMB imines, followed by high temperature annulation provided 25a-d. TBS deprotection followed by LiI-mediated ester dealkylation gave the hydroxy acid intermediates $\mathbf{2 6 a - d}$. Alcohol oxidation provided the indole-2-carboxaldehydes $27 \mathbf{a}-\mathbf{d}$. Reductive amination followed by TFA-mediated DMB deprotection provided the final targets 4a, 5a, 6a, 6b, 6i, 6n, 6p, 6r, 6v, 6z, 6bb, 6dd, and 7 a.

Tetracyclic derivatives fused through a seven-membered ring tether bearing an oxygen atom at the position adjacent to the indole core were obtained via the TBS-protected indolyl cyclic ketone intermediate 35 (Scheme 4). Compound 28 was obtained by etherification of 3-bromo-4-hydroxybenzaldehyde followed by condensation with ethyl azidoacetate. Hemetsberger $^{23}$ cyclization followed by $N$-methylation of the resulting indole gave ethyl indole-2-carboxylate 30. DIBAL-H reduction followed by TBS protection of the resultant alcohol and metal- 
Table 1. In Vitro Antibacterial Activity of 5-Indolyl-4-hydroxy-2-pyridones

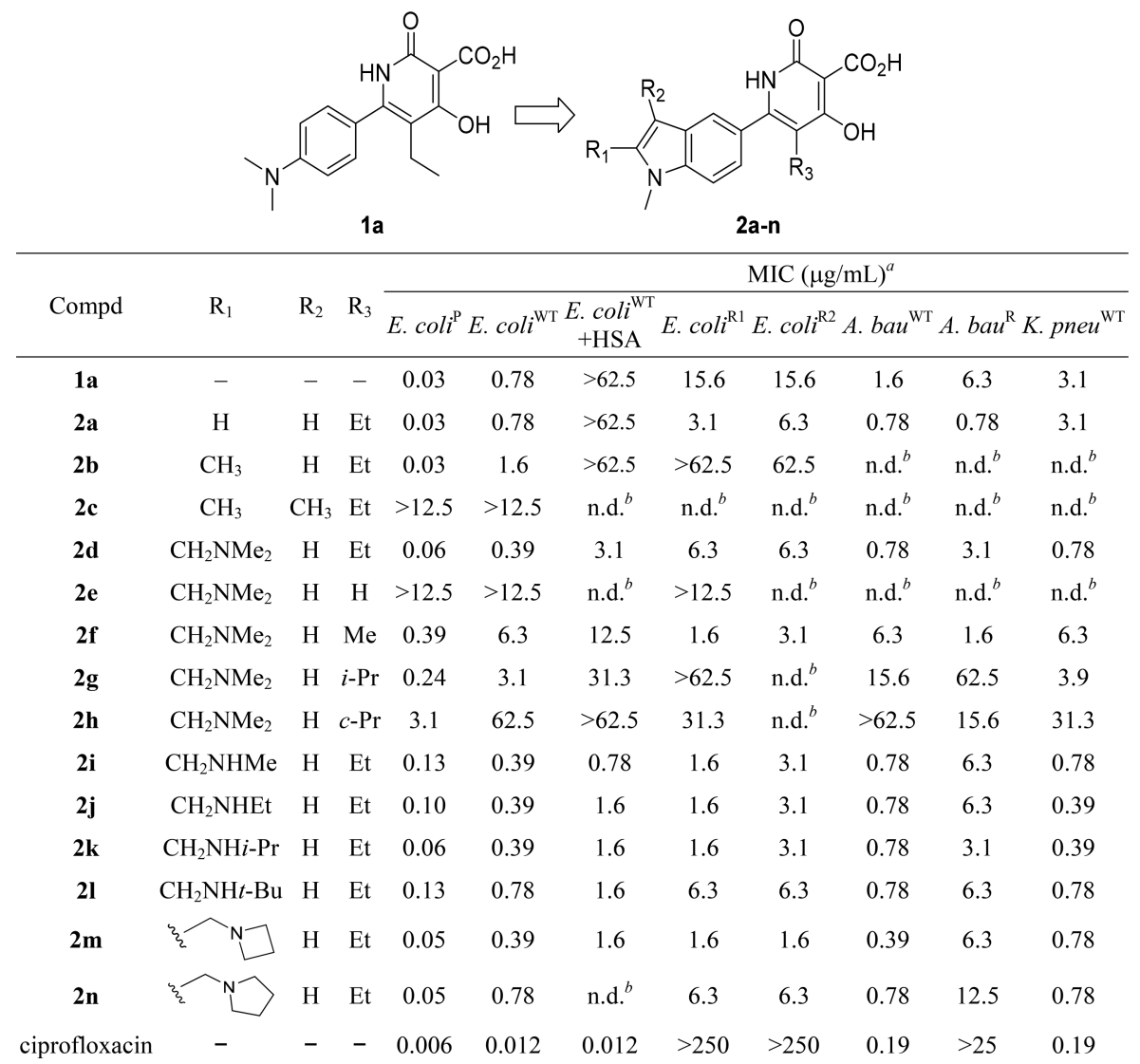

${ }^{a}$ Minimum inhibitory concentration. E. coli ${ }^{\mathrm{P}}=$ E. coli BAS849; E. coli ${ }^{\mathrm{WT}}=$ E. coli ATCC $25922 ;$ E. coli ${ }^{\mathrm{R} 1}=$ E. coli SKM18; E. coli ${ }^{\mathrm{R} 2}=$ E. coli ELZ4251; A. bau $^{\mathrm{WT}}=$ A. baumannii ATCC BAA-747; A. bau ${ }^{\mathrm{R}}=$ A. baumannii MMX2240; K. pneu ${ }^{\mathrm{WT}}=K$. pneumoniae ATCC $35657 .{ }^{b}$ Not determined.

halogen exchange of the 5-bromo indole derivative followed by formylation gave 5-formylindole 32. Vinylmagnesium bromide addition followed by olefin metathesis gave 34 . Oxidation of the alcohol and subsequent hydrogenation of the double bond gave the cyclic ketone intermediate 35 . Transformation of 35 to the indole-2-carboxaldehydes 39 was carried out via the four-step sequence described previously. Reductive amination and DMB deprotection provided the final targets $6 \mathrm{c}, 6 \mathrm{f}, 6 \mathrm{j}, 6 \mathrm{o}, \mathbf{6 q}, \mathbf{6 s}, \mathbf{6 w}$, 6aa, 6cc, and 6ee.

The azepino-indole 4-hydroxy-2-pyridones $6 \mathrm{~d}, \mathbf{6 g}$, and 61 were prepared analogously to the oxepino-indole 4-hydroxy-2pyridones described in Scheme 4 as detailed in the Supporting Information. Thiepino-indole 4-hydroxy-2-pyridones $\mathbf{6 e}, \mathbf{6 h}$, $6 \mathrm{~m}, 6 \mathrm{u}$, and $6 \mathrm{y}$ were prepared via straightforward chemistry, first building a masked 4-hydroxy-2-pyridone before constructing the substituted indole moiety as detailed in the Supporting Information. Compounds $\mathbf{6 k}$, $\mathbf{6 t}$, and $\mathbf{6 x}$, substituted with $\mathrm{O}$ in the middle of the three-atom tether, were prepared as described in the Supporting Information. Regioisomeric tetracyclic 4hydroxy-2-pyridones $\mathbf{8} \mathbf{a}$ and $\mathbf{8 b}$ were prepared as described in the Supporting Information.

Lead Optimization. MIC values were measured against a panel of wild-type and resistant Gram-negative strains, including permeable Escherichia coli BAS849 ${ }^{24}$ (E. coli ${ }^{\mathrm{P}}$ ), wildtype E. coli ATCC 25922 (E. coli ${ }^{\mathrm{WT}}$ ), highly fluoroquinolone resistant $E$. coli strains SKM18 (E. coli $\left.{ }^{\mathrm{R} 1}\right),{ }^{25}$ bearing four mutations (two in gyrA and two in parC) in the quinolone resistance-determining region ( $Q R D R)$, and clinical isolate ELZ4251 (E. coli $\left.{ }^{\mathrm{R} 2}\right){ }^{26}$ Additionally, wild-type strains of
Acinetobacter baumannii ATCC BAA-747 (A. bau $\left.{ }^{\mathrm{WT}}\right)$ and Klebsiella pneumoniae ATCC 35657 (K. pneu ${ }^{\mathrm{WT}}$ ) as well as fluoroquinolone resistant clinical isolate $A$. baumannii $\operatorname{MMX} 2240\left(A . b_{a u}\right)^{27}$ were routinely screened against. Bacterial MICs were determined by following CLSI guidelines with the exception that organisms were grown in brain-heartinfusion media. ${ }^{28}$ As a surrogate measure of serum shift, MICs were also determined against E. coli ${ }^{\mathrm{WT}}$ in the presence of 40 $\mathrm{mg} / \mathrm{mL}$ of human serum albumin (HSA).

Previously, we described the discovery and optimization of aminophenyl-substituted 4-hydroxy-2-pyridones active against multidrug resistant (MDR) Gram-negative bacteria and the requirement of the 4-hydroxy group as a key pharmacophoric structural feature for imparting activity against fluoroquinolone resistant strains. ${ }^{15}$ Compound la exhibited good activity against several wild-type Gram-negative strains including E. coli ${ }^{\mathrm{WT}}, A$. $b_{a u}{ }^{\mathrm{WT}}$, and $K$. pneu $^{\mathrm{WT}}$ (MIC values of $0.78,1.6$, and $3.1 \mu \mathrm{g} / \mathrm{mL}$, respectively) and modest activity (MIC $=15.6 \mu \mathrm{g} / \mathrm{mL})$ against the highly fluoroquinolone resistant E. coli strain SKM18 (E. coli $\left.^{\mathrm{R} 1}\right)$. Similar activity was observed against the fluoroquinolone resistant E. coli clinical isolate ELZ4251 (E. coli ${ }^{\mathrm{R} 2}$ ) (Table 1).

As a part of a lead optimization campaign focused on improving activity against resistant Gram-negative strains, we envisioned fusing the dimethylamino group onto the phenyl ring, thereby replacing the aniline motif with an indole scaffold, obtaining the 5-indolyl-4-hydroxy-2-pyridone 2a. Compared to 1a, compound 2 a had similar activity against the wild-type strains of E. coli, A. baumannii, and K. pneumoniae but exhibited 
a 2- to 8-fold reduction in MICs against the E. coli and $A$. baumannii resistant strains. Adding $\mathrm{Me}$ to $\mathrm{R}_{1}(\mathbf{2 b})$ had a detrimental effect on activity against the resistant $E$. coli strains while adding an additional Me group at $\mathrm{R}_{2}(2 \mathrm{c})$ led to complete loss of activity against the strains evaluated. Compounds $2 \mathrm{a}$ and 2b exhibited a $>40$-fold shift in the MIC in the presence of HSA. A greater than 25-fold increase in MIC values against the wild-type E. coli strain compared to the permeable strain in compounds $\mathbf{2 a}$ and $\mathbf{2} \mathbf{b}$ suggest that either limited membrane permeability and/or drug efflux are contributing factors to the reduction in activity. Appending a basic nitrogen atom to $R_{1}$ in 2b (e.g., 2d) resulted in marked improvement in MICs including an 8 -fold reduction in MIC shift between E. coli ${ }^{\mathrm{WT}}$ and E. coli ${ }^{\mathrm{P}}$. The basic nitrogen atom renders $\mathbf{2 d}$ zwitterionic, which could result in improved porin transit. ${ }^{29}$ Further, the basic nitrogen in $\mathbf{2 d}$ resulted in a $>4$-fold reduction in the MIC shift in the presence of HSA against $E$. coli ${ }^{\mathrm{WT}}$ compared to $\mathbf{2 b}{ }^{15}$

We next evaluated the effect of the $\mathrm{R}_{3}$ substituent size on antibacterial activity (Table 1 ). Compared to $\mathbf{2 d}$, replacement of $\mathrm{R}_{3}$ with $\mathrm{H}(\mathbf{2 e})$ resulted in a dramatic reduction in activity while replacement with $\mathrm{Me}$ (2f) exhibited a 4- to 8-fold reduction in activity against the wild-type strains but a 2- to 4fold improvement in activity against the resistant strains. Compared to $\mathbf{2 d}$, a small increase in substituent size, e.g., $i-\operatorname{Pr}$ $(\mathbf{2 g})$ and $c$ - $\operatorname{Pr}(\mathbf{2 h})$, led to reduced activity. Overall, Et substitution at $R_{3}$ provided the best balance of antibacterial activity and was utilized for further SAR investigations.

Additional aliphatic secondary and tertiary basic amines $(\mathbf{2} \mathbf{i}-$ 2n) appended to the indole $R_{2}$ were next investigated (Table 1). In general, these compounds displayed similar MICs (within 4-fold) compared to $\mathbf{2 d}$ against the bacterial panel, exhibiting some tolerance to substituent size at $\mathrm{R}_{2}$. Increased MIC shifts in the presence of HSA were generally 2- to 4-fold. Overall, while compounds $\mathbf{2 d}$ and $\mathbf{2} \mathbf{i}-\mathbf{m}$ exhibited elevated MICs against $E$. coli ${ }^{\mathrm{WT}}$, they exhibited far superior activity against the fluoroquinolone resistant strains E. coli ${ }^{\mathrm{R} 1}$ and E. coli ${ }^{\mathrm{R} 2}$ compared to the control compound, ciprofloxacin.

Noting the effect of $\mathrm{R}_{3}$ on antibacterial activity, we surmised that the dihedral angle between the indole and 2-pyridone rings might play an important role. To gain better insight into the preferred conformational state of the biaryl system, we generated an energy profile for a model compound $\left(\mathbf{2} \mathbf{b}, \mathrm{R}_{1}=\right.$ $\mathrm{Me}$ ) encompassing a full $360^{\circ}$ rotation around the $\mathrm{C}-\mathrm{C}$ bond between the indole and 2-pyridone rings (Figure 2). ${ }^{30}$ In the lowest energy conformation, the dihedral angle $(\theta)$ between the two rings is $129^{\circ}$. In this twisted conformation, the steric clash between the 2-pyridone ethyl group and the indole C-4 and C6 hydrogens is reduced, while retaining considerable aromatic conjugation in the biaryl system. Further, the energy profile

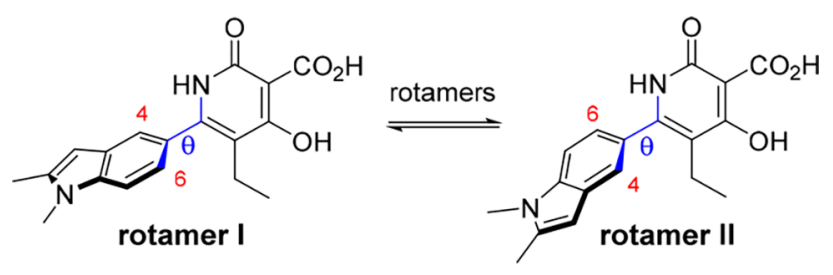

$$
\begin{gathered}
\Delta \mathrm{E}=0.01 \mathrm{kcal} / \mathrm{mol} \\
\theta=129^{\circ}
\end{gathered}
$$

Figure 2. Rotation about the $\mathrm{C}-\mathrm{C}$ bond in the 5-indolyl-4-hydroxy-2pyridones. revealed two energetically equivalent rotamers differing in the position of the indole nitrogen atom facing either "in" or "out" of the plane as depicted in Figure 2 (see Supplemental Graph 1).

We next restricted the rotation around the $\mathrm{C}-\mathrm{C}$ bond joining the two rings by introducing a tether between the pyridone ring ethyl group and the indole ring as a means to gain an entropic advantage and potentially increase antibacterial activity. We had two objectives: (1) determine the optimal tether length conferring maximum activity and (2) determine whether rotamer I or rotamer II is the preferred conformation. To address this, we modeled four tetracyclic systems containing tethers of one to four carbons (forming 5- to 8-membered rings) between the pyridone C-5 and the indole C-6 ([5,6]fusion nomenclature) and determined their equilibrium geometries and the dihedral angle for those conformations (Table 2). As expected, the five-membered ring system is completely rigid with $\theta=180^{\circ}$. Adding an additional carbon atom to the tether (six-membered ring) allowed for some flexibility with a predicted dihedral angle of $160^{\circ}$ in the most energetically stable conformation. Further increasing the size of the tether to seven- and eight-membered rings allowed for several conformations with predicted optimal $\theta$ values of $135^{\circ}$ and $123^{\circ}$, respectively. In Figure 3, each of the optimized constrained tetracyclic analogues is overlaid with the acyclic analogue $\mathbf{2 b}$ in its most energetically stable conformation. The seven- and eight-membered ring tethered compounds, with optimal dihedral angles similar to the acyclic analogue, provided the best overlay of the indole and 2-pyridone rings. The fiveand six-membered ring tethered compounds placed the indole ring in different spatial orientations.

To confirm the effect of the predicted geometries on the antibacterial activity, we prepared the four tethered tetracyclic compounds $4 a-7 a$ containing basic amines appended to the indole $\mathrm{R}_{1}$ (Table 2). Good correlation between the dihedral angle and activity was observed. Compound $4 \mathrm{a}$, most structurally dissimilar to acyclic compound $2 \mathrm{j}\left(\mathrm{R}_{1}=\right.$ $\mathrm{CH}_{2} \mathrm{NHEt}$ ), was essentially inactive against the $E$. coli strains. Compounds $\mathbf{6 a}$ and $7 \mathbf{a}$, most similar to acyclic analogue $\mathbf{2 j}$, provided the best activity with seven-membered ring analogue 6a demonstrating a 4-fold reduction in MIC value against $E$. coli $^{\mathrm{R} 1}$ compared to $2 \mathrm{j}$. We also determined inhibitory activities against the target enzymes DNA gyrase and Topo IV. ${ }^{31}$ Similar to the effect on MIC values, 6a exhibited greater potency against the target enzymes than the other tethered analogues. These results prompted an expanded SAR investigation of the seven-membered ring tethered tetracyclic series.

We then assessed whether the active conformation was better defined by sterically constrained rotamer I or II (Figure 2). Compounds $\mathbf{8 a}$ and $\mathbf{8 b}$, containing a three-carbon tether (seven-membered ring) between the pyridone $\mathrm{C}-5$ and the indole C-4 ([5,4] fusion), restrict the conformation in the form of rotamer II (Figure 2, Table 3). Unlike the two rotamers shown for $\mathbf{2} \mathbf{b}$ in Figure 2, the $[5,6]$ - and [5,4]-regiosomeric tetracycles cannot interconvert (Table 3 ). The data indicate a clear activity preference toward the $[5,6]$-fused regioisomers. Compared to $\mathbf{6 a}$ and $\mathbf{6 b}$, the $[5,4]$-fused regioisomers $8 \mathbf{a}$ and $8 b$ resulted in a $>30$-fold increase in MIC values against $E$. coli ${ }^{\mathrm{P}}$ and $E$. coli ${ }^{\mathrm{WT}}$ and a 16 -fold increase in MIC values against $E$. coli $^{\mathrm{R} 1}$, respectively. Compounds $\mathbf{8 a}$ and $\mathbf{8 b}$ also demonstrated a 5- to 10 -fold reduction in inhibitory activity against the E. coli target enzymes, DNA gyrase and Topo IV. 
Table 2. In Vitro Antibacterial Activity of Constrained Analogs: Ring Size

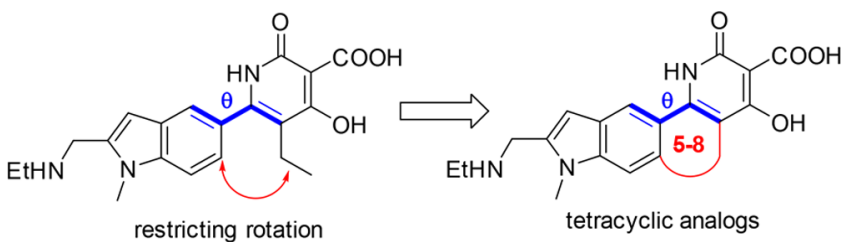

\begin{tabular}{|c|c|c|c|c|c|c|c|}
\hline \multirow[b]{2}{*}{ ring size } & \multirow[b]{2}{*}{ compd } & \multirow[b]{2}{*}{ dihedral angle $^{a}$ (calcd) } & \multicolumn{3}{|c|}{$\operatorname{MIC}(\mu \mathrm{g} / \mathrm{mL})^{b}$} & \multicolumn{2}{|c|}{$\begin{array}{c}\text { E. coli enzymatic activity }{ }^{c}\left(\mathrm{IC}_{50}\right. \\
\mu \mathrm{M})\end{array}$} \\
\hline & & & E. coli ${ }^{\mathrm{P}}$ & E. coli $^{\mathrm{WT}}$ & E. coli $^{\mathrm{R} 1}$ & DNA gyrase & Topo IV \\
\hline acyclic & $2 j$ & 129 & 0.10 & 0.39 & 1.6 & 0.3 & 3.3 \\
\hline five-membered & $4 a$ & 180 & $>12.5$ & $>62.5$ & $>62.5$ & $>11.1^{e}$ & $>11.1^{e}$ \\
\hline six-membered $^{d}$ & $5 a$ & 160 & 3.1 & 7.8 & 7.8 & 0.9 & 37.7 \\
\hline seven-membered & $6 a$ & 135 & 0.10 & 0.39 & 0.39 & 0.1 & 2.9 \\
\hline eight-membered & $7 \mathbf{a}$ & 123 & 0.19 & 0.78 & 3.1 & 0.8 & 15.3 \\
\hline ciprofloxacin & & & 0.006 & 0.012 & $>250$ & 0.19 & 3.5 \\
\hline
\end{tabular}

${ }^{a}$ Calculated energy minimized dihedral angles. See ref $30 .{ }^{b}$ Minimum inhibitory concentration. E. coli ${ }^{\mathrm{P}}=$ E. coli BAS849; E. coli ${ }^{\mathrm{WT}}=$ E. coli ATCC 25922; E. coli ${ }^{\mathrm{R} 1}=$ E. coli SKM18. ${ }^{c}$ See ref $31 .{ }^{d}$-Methylamino analogue. ${ }^{e}$ Highest concentration tested.
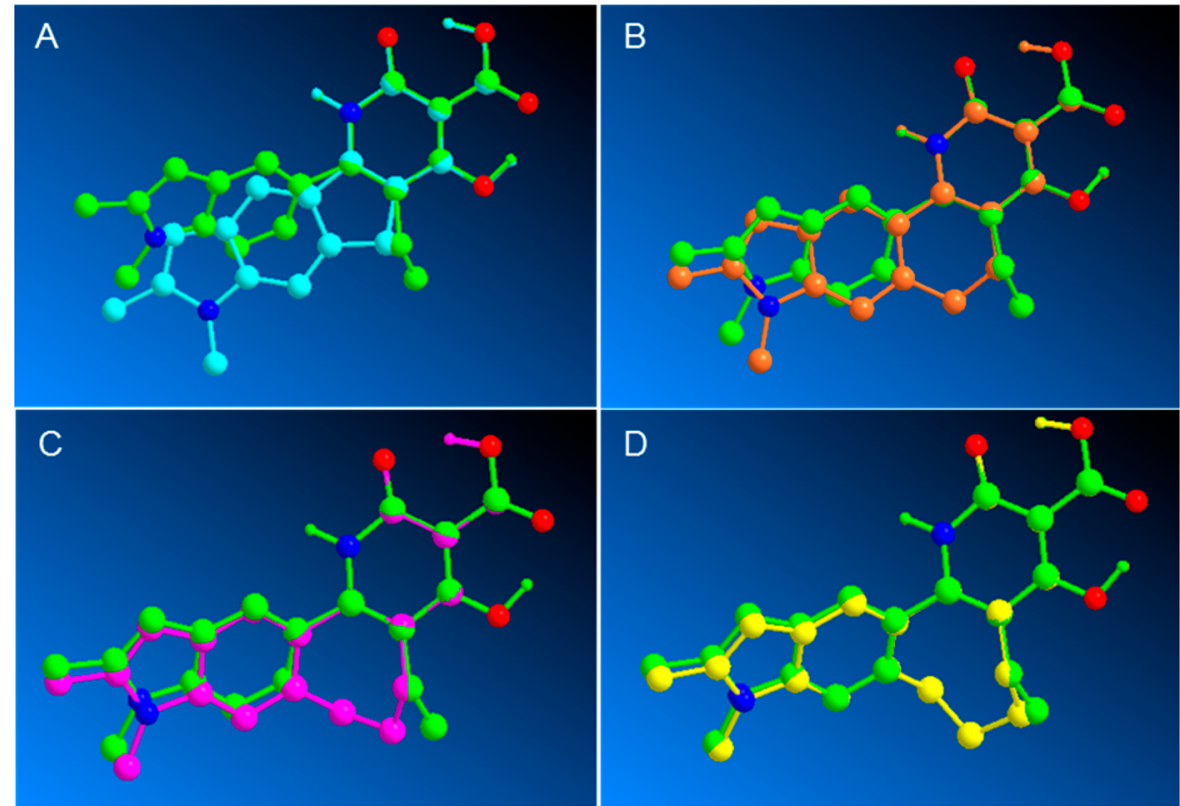

Figure 3. Structural overlays of constrained analogs: (A) $\mathbf{2 b}$ (green) and five-membered ring constrained analogue (blue); (B) $\mathbf{2 b}$ and six-membered ring constrained analogue (orange); (C) $\mathbf{2 b}$ and seven-membered ring constrained analogue (red); (D) $2 \mathbf{b}$ and eight-membered ring constrained analogue (yellow).

Inspired by the activity profiles of $\mathbf{6 a}$ and $\mathbf{6 b}$, we sought to further investigate the tetracyclic series in more detail. Having determined the optimal tether length (three atoms) and preference for $[5,6]$-fusion, we next investigated two additional points of diversity: incorporation of heteroatoms in the linker and modification of the basic amine groups appended to the indole C-2 (Table 4). Several analogs containing secondary and tertiary aliphatic amines $\left(\mathrm{NR}_{\mathrm{a}} \mathrm{R}_{\mathrm{b}}\right)$ were evaluated. For compounds containing a three-carbon tether $\left(\mathrm{X}, \mathrm{Y}=\mathrm{CH}_{2}\right.$, cyclohepta $[1,2-f]$ indole), secondary amines $\mathbf{6 a}, \mathbf{6 b}, \mathbf{6 i}, \mathbf{6 n}$, and $\mathbf{6 p}$ and tertiary amines $\mathbf{6 r}$ and $\mathbf{6 v}$ exhibited similar activity against wild-type strains of E. coli, A. baumannii, and $K$. pneumoniae with MIC values ranging from 0.39 to $1.6 \mu \mathrm{g} / \mathrm{mL}$. Compared to E. coli ${ }^{\mathrm{WT}}$, MIC values against E. coli ${ }^{\mathrm{R} 1}$ and E. coli ${ }^{\mathrm{R} 2}$ typically increased 2- to 4-fold, while activity against $A$. bau ${ }^{\mathrm{R}}$ was generally similar to $A$. bau ${ }^{\mathrm{WT}}$. These compounds exhibited a 4- to 16-fold shift in MIC values in the presence of $40 \mathrm{mg} / \mathrm{mL}$ of HSA. Antibacterial activity was generally independent of the nature of the aliphatic amines evaluated.

Replacement of the methylene group with an oxygen atom at the $\alpha$-position of the tether $\left(\mathrm{X}=\mathrm{O}, \mathrm{Y}=\mathrm{CH}_{2}\right.$, oxepino[3,2$f$ ]indole) resulted in a different SAR profile. For compounds with small secondary amines, e.g., $6 \mathrm{c}(\mathrm{Me})$ and $\mathbf{6 f}(\mathrm{Et}), \mathrm{MIC}$ values generally increased 2- to 4 -fold against $E$. coli ${ }^{\mathrm{WT}}$ and $E$. coli $^{\mathrm{R} 1}$ compared to the respective methylene analogues ( $6 \mathbf{b}$ and 6a), while more dramatic shifts in MICs (8- to 16-fold) were observed against E. coli ${ }^{\mathrm{R} 2}, A . b a u^{\mathrm{WT}}$, and $A$. $b a u^{\mathrm{R}}$. For oxepino $[3,2-f]$ indoles containing branched secondary amines, e.g., 6j (i-Pr), 6o (sec-Bu), 6q (1-Me-c-Bu), and tertiary amines $\mathbf{6 s}$ (dimethyl) and $\mathbf{6 w}$ (pyrrolidine), MIC values were similar to the analogous cyclohepta[1,2-f]indole analogues. The increased polarity imparted by the tether oxygen in the oxepino $[3,2-f]$ indole series resulted in smaller MIC shifts (2to 4-fold) in the presence of HSA compared to similar 
Table 3. In Vitro Antibacterial Activity of Constrained Analogs: [5,6]- vs. [5,4]-Fused Regioisomers

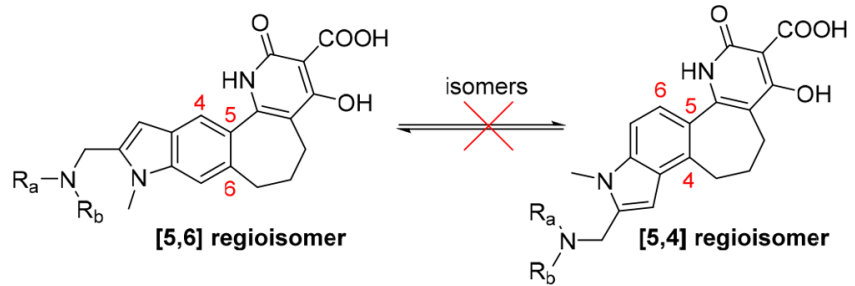

\begin{tabular}{|c|c|c|c|c|c|c|c|}
\hline \multirow[b]{2}{*}{ compd } & \multirow[b]{2}{*}{ fusion } & \multirow[b]{2}{*}{$\mathrm{NR}_{\mathrm{a}} \mathrm{R}_{\mathrm{b}}$} & \multicolumn{3}{|c|}{$\operatorname{MIC}(\mu \mathrm{g} / \mathrm{mL})^{a}$} & \multicolumn{2}{|c|}{ E. coli enzymatic activity ${ }^{b}\left(\mathrm{IC}_{50}, \mu \mathrm{M}\right)$} \\
\hline & & & E. coli $^{\mathrm{P}}$ & E. coli $^{\mathrm{WT}}$ & E. coli $^{\mathrm{RI}}$ & DNA gyrase & Topo IV \\
\hline $6 \mathrm{~b}$ & {$[5,6]$} & $\mathrm{NHMe}$ & 0.19 & 0.39 & 0.39 & 0.1 & 3.7 \\
\hline $6 a$ & {$[5,6]$} & NHEt & 0.10 & 0.39 & 0.39 & 0.1 & 2.9 \\
\hline $8 \mathbf{a}$ & {$[5,4]$} & $\mathrm{NHMe}$ & 6.3 & $>12.5$ & 6.3 & 1.0 & 27.9 \\
\hline $8 b$ & {$[5,4]$} & NHEt & 6.3 & 12.5 & 6.3 & n.d. ${ }^{c}$ & 19.0 \\
\hline ciprofloxacin & & & 0.006 & 0.012 & $>250$ & 0.19 & 3.5 \\
\hline
\end{tabular}

${ }^{a}$ Minimum inhibitory concentration. E. coli ${ }^{\mathrm{P}}=$ E. coli BAS849; E. coli ${ }^{\mathrm{WT}}=$ E. coli ATCC 25922; E. coli ${ }^{\mathrm{R} 1}=$ E. coli SKM18. ${ }^{b}$ See ref $31 .{ }^{c}$ Not determined.

analogues with the all-carbon tether (4- to 16-fold shifts). Compounds 60 and $\mathbf{6 q}$ displayed good antibacterial activity across the panel of strains (MICs $\leq 2 \mu \mathrm{g} / \mathrm{mL}$ ) and exhibited similar or lower MICs against the resistant strains of E. coli and A. baumannii compared to the corresponding wild-type strains.

Transposition of the oxygen atom to the $\beta$ position of the tether $\left(\mathrm{X}=\mathrm{CH}_{2}, \mathrm{Y}=\mathrm{O}\right.$, oxepino $[4,3-f]$ indole $)$ resulted in an overall reduction in antibacterial activity. Compounds $6 \mathbf{k}$ and 6t exhibited higher MIC values against wild-type E. coli and both the wild-type and resistant strains of $A$. baumannii compared to the congener pairs $6 \mathbf{i}, \mathbf{6 j}$ and $\mathbf{6 r}, \mathbf{6 s}$, respectively. In contrast, against the highly fluoroquinolone resistant strain E. coli ${ }^{\mathrm{R} 1}, \mathbf{6 k}$ and $\mathbf{6 t}$ exhibited similar activity to the related congeners.

Introduction of a polar, hydrogen bond donating amine $(\mathrm{X}=$ $\mathrm{NH}, \mathrm{Y}=\mathrm{CH}_{2}$, azepino[3,2-f]indole) at the $\alpha$-position of the tether was generally disfavored. Compounds $\mathbf{6 d}, \mathbf{6 g}$, and $\mathbf{6 1}$ exhibited modest to weak antibacterial activity against $E$. coli ${ }^{\mathrm{WT}}$ and the clinical isolate E. coli $\mathrm{R}^{\mathrm{R}}$ as well as wild-type and resistant A. baumannii and modest activity against K. pneu ${ }^{\mathrm{WT}}$. It should be noted that all three compounds exhibited improved antibacterial activity against the highly fluoroquinolone resistant strain $E$. coli $^{\mathrm{R} 1}(\mathrm{MIC}=3.9 \mu \mathrm{g} / \mathrm{mL})$ compared to the wild-type strain (MIC range $7.8-31.3 \mu \mathrm{g} / \mathrm{mL}$ ). Although the polar nitrogen atom in the tether generally resulted in no shift in MIC values in the presence of HSA, these compounds generally exhibited weak antibacterial activity.

Replacement of the methylene group with the larger, more lipophilic sulfur atom at the $\alpha$-position of the tether $(\mathrm{X}=\mathrm{S}, \mathrm{Y}=$ $\mathrm{CH}_{2}$, thiepino[3,2-f]indole) resulted in a 2- to 4-fold decrease in antibacterial activity (compounds $6 \mathrm{e}, 6 \mathrm{~h}, 6 \mathrm{~m}, 6 \mathrm{u}$, and $6 \mathrm{y}$ ). As a consequence of the longer $\mathrm{C}-\mathrm{S}$ bond lengths $(\sim 1.8 \AA$ vs $\sim 1.5 \AA$ for $\mathrm{C}-\mathrm{C}$ bonds), the topology of the tetracyclic series is altered, effectively lengthening the tether to between that of a three and four carbon chain. As a result of the increased lipophilicity, an 8- to 16-fold shift in E. coli ${ }^{\mathrm{WT}} \mathrm{MICs}$ in the presence of HSA was observed for these analogues.

We next evaluated the effect on antibacterial activity of adding additional heteroatoms to the basic amine moiety in both the cyclohepta[1,2-f]indole $\left(\mathrm{X}=\mathrm{CH}_{2}\right)$ and oxepino[3,2$f$ ]indole $(\mathrm{X}=\mathrm{O})$ series $(\mathbf{6 z}$ and $6 \mathbf{a a}-6 \mathbf{e e})$. Substitution of the alkyl amine moiety with OMe favored the carbon-fused analogue $(6 z)$ compared to the oxygen-fused analogue (6aa) with no net improvement in activity compared to the corresponding ethylamino analogues $\mathbf{6 a}$ and $\mathbf{6 f}$, respectively. Adding a second basic amine moiety $\left(\mathrm{NMe}_{2}\right)$ to the alkyl amine group ( $6 \mathrm{bb}$ and $\mathbf{6 c c}$ ) resulted in elevated MIC values across multiple strains. Methoxy-substituted pyrrolidine $\mathbf{6 d d}$ provided activity similar to $\mathbf{6 v}$, while similar substitution of the oxygenfused analogue (6ee) resulted in increased MIC values across several strains.

To more readily visualize activity differences, data are presented graphically in the Spotfire plot depicted in Figure 4 in which antibacterial activities against $E$. coli ${ }^{\mathrm{R} 1}$ and $A$. baumannii ${ }^{\mathrm{R}}$ are compared across four series (acyclic and three cyclic series) containing ten distinct amine fragments. ${ }^{32}$ The seven-membered carbon tethered 4-hydroxy-2-pyridones (cyclohepta[1,2-f]indoles, blue circles) display a marked improvement in MICs against both $E$. coli ${ }^{\mathrm{R} 1}$ and $A$. baumannii ${ }^{\mathrm{R}}$ compared to the acyclic series (5-indolyl-4-hydroxy-2-pyridones, black circles). The fused oxepino[3,2-f]indoles (red circles) and thiepino[3,2-f]indoles (green circles) generally show a 2- to 4-fold improvement in MICs against E. coli ${ }^{\mathrm{R} 1}$, but no obvious overall improvement against $A$. baumannii ${ }^{\mathrm{R}}$.

Preliminary Mechanistic Evaluation. Compound 2m, an early representative analogue, was evaluated against wild-type strains of both E. coli and A. baumannii at several concentrations to determine the mode of bacterial inhibition. As shown in the time-kill kinetics plot (Figure 5), $2 \mathrm{~m}$ shows concentration-dependent bactericidal activity against both pathogens. Rapid killing is observed at concentrations above the MIC against E. coli (Figure 5a) and above 2-fold of the MIC of $2 \mathrm{~m}$ against $A$. baumannii (Figure $5 \mathrm{~b}$ ). At these concentrations, reduction in the number of CFUs (colony forming units) by more than $3 \log _{10}$ units occurred within $\sim 2 \mathrm{~h}$ in the $E$. coli strain and $\sim 2 \log _{10}$ units within the same time period for the A. baumannii strain. This concentration-dependent killing kinetics mirrors what was observed for the known bactericidal antibiotic ciprofloxacin (Supporting Information, Figure 1).

To explain the enhanced activity observed for the 4-hydroxy2-pyridones against fluoroquinolone resistant strains, we compared the activities of $\mathbf{6 a}$ and ciprofloxacin against wildtype E. coli DNA gyrase $\left(\mathrm{GyrA}^{\mathrm{WT}}\right)$ and DNA gyrase that contain two mutations in QRDR, S83L and D87Y (GyrA $\left.{ }^{\mathrm{SD}-\mathrm{LY}}\right)$, 
Table 4. In Vitro Antibacterial Activity of Amine Substitution

\begin{tabular}{|c|c|c|c|c|c|c|c|c|c|}
\hline \multirow[b]{2}{*}{ Compd } & \multirow[b]{2}{*}{$\mathrm{Y}$} & \multirow[b]{2}{*}{$\mathrm{NR}_{\mathrm{a}} \mathrm{R}_{\mathrm{b}}$} & \multicolumn{7}{|c|}{ MIC $(\mu \mathrm{g} / \mathrm{mL})^{a}$} \\
\hline & & & E. $\operatorname{coli}^{\mathrm{WT}}$ & E. coli ${ }^{\mathrm{W}}$ & E. coli ${ }^{\mathrm{R}}$ & E. coli ${ }^{\mathrm{R}}$ & A. $b a u^{\mathrm{W}}$ & A. $b a u^{\mathrm{R}}$ & K. pneu" \\
\hline $6 \mathrm{~b}$ & $\mathrm{CH}_{2} \mathrm{CH}_{2}$ & NHMe & 0.39 & 3.1 & 0.39 & 0.8 & 1.6 & 1.6 & 0.39 \\
\hline $6 c$ & $\mathrm{O} \quad \mathrm{CH}_{2}$ & NHMe & 1.6 & 3.1 & 0.78 & $>12.5$ & 12.5 & $>12.5$ & 1.6 \\
\hline $6 d$ & $\mathrm{NH} \mathrm{CH}{ }_{2}$ & NHMe & 31.3 & 31.3 & 3.9 & $>62.5$ & $>25$ & $>25$ & 6.3 \\
\hline $6 e$ & $\mathrm{~S} \quad \mathrm{CH}_{2}$ & $\mathrm{NHMe}$ & 1.0 & 7.8 & 0.49 & 1.6 & 3.9 & 7.8 & 1.0 \\
\hline 6a & $\mathrm{CH}_{2} \mathrm{CH}_{2}$ & NHEt & 0.39 & 6.3 & 0.39 & 1.6 & 0.78 & 1.6 & 0.78 \\
\hline 6f & $\mathrm{O} \mathrm{CH}_{2}$ & NHEt & 0.78 & 1.6 & 0.78 & 12.5 & 12.5 & 12.5 & 0.78 \\
\hline $6 \mathrm{~g}$ & $\mathrm{NH} \mathrm{CH} \mathrm{CH}_{2}$ & NHEt & 15.6 & 15.6 & 3.9 & $>62.5$ & $>25$ & $>25$ & 6.3 \\
\hline $6 \mathrm{~h}$ & $\mathrm{~S} \quad \mathrm{CH}_{2}$ & NHEt & 1.0 & 15.6 & 0.5 & 1.6 & 3.9 & 3.9 & 1.0 \\
\hline $6 \mathbf{i}$ & $\mathrm{CH}_{2} \mathrm{CH}_{2}$ & $\mathrm{NH} i-\mathrm{Pr}$ & 0.78 & 3.1 & 0.39 & 1.6 & 0.78 & 0.78 & 0.78 \\
\hline $6 \mathbf{j}$ & $\mathrm{O} \quad \mathrm{CH}_{2}$ & $\mathrm{NH} i-\mathrm{Pr}$ & 0.49 & 2.0 & 0.49 & 1.0 & 3.9 & 6.3 & 1.6 \\
\hline $6 \mathrm{k}$ & $\mathrm{CH}_{2} \mathrm{O}$ & $\mathrm{NH} i-\mathrm{Pr}$ & 12.5 & n.d. ${ }^{b}$ & 0.78 & n.d. ${ }^{b}$ & $>50$ & $>50$ & 3.1 \\
\hline 61 & $\mathrm{NH} \mathrm{CH} \mathrm{CH}_{2}$ & $\mathrm{NH} i-\mathrm{Pr}$ & 7.8 & 7.8 & 3.9 & 62.5 & $>25$ & $>25$ & 6.3 \\
\hline $6 \mathrm{~m}$ & $\mathrm{~S} \quad \mathrm{CH}_{2}$ & $\mathrm{NH} i-\mathrm{Pr}$ & 2.0 & 15.6 & 1.0 & 3.1 & 2.0 & 3.9 & 2.0 \\
\hline $6 n$ & $\mathrm{CH}_{2} \mathrm{CH}_{2}$ & $\mathrm{NH} s-\mathrm{Bu}$ & 0.78 & 3.1 & 0.78 & 1.6 & 0.78 & 0.50 & 0.50 \\
\hline 60 & $\mathrm{O} \quad \mathrm{CH}_{2}$ & $\mathrm{NH} s-\mathrm{Bu}$ & 0.78 & 1.6 & 0.78 & 2.0 & 1.6 & 0.78 & 1.0 \\
\hline $6 p$ & $\mathrm{CH}_{2} \mathrm{CH}_{2}$ & $\stackrel{-N H}{\longrightarrow}$ & 1.0 & 7.8 & 1.0 & n.d. ${ }^{b}$ & 0.50 & 1.0 & 1.0 \\
\hline $6 q$ & $\mathrm{O} \quad \mathrm{CH}_{2}$ & $\stackrel{-N H}{\longrightarrow}$ & 1.0 & 3.9 & 0.50 & 0.78 & 0.50 & 0.50 & 1.0 \\
\hline $6 \mathbf{r}$ & $\mathrm{CH}_{2} \mathrm{CH}_{2}$ & $\mathrm{NMe}_{2}$ & 0.78 & 12.5 & 0.78 & 1.6 & 1.6 & 1.6 & 0.78 \\
\hline $6 \mathrm{~s}$ & $\mathrm{O} \quad \mathrm{CH}_{2}$ & $\mathrm{NMe}_{2}$ & 1.0 & 2.0 & 1.0 & 1.6 & 2.0 & 3.9 & 1.0 \\
\hline $6 t$ & $\mathrm{CH}_{2} \mathrm{O}$ & $\mathrm{NMe}_{2}$ & 6.3 & n.d..$^{b}$ & 0.78 & n.d. ${ }^{b}$ & 25 & 25 & 3.1 \\
\hline $6 u$ & $\mathrm{~S} \quad \mathrm{CH}_{2}$ & $\mathrm{NMe}_{2}$ & 2.0 & 31.2 & 2.0 & n.d. ${ }^{b}$ & 2.0 & 3.9 & 2.0 \\
\hline $6 v$ & $\mathrm{CH}_{2} \mathrm{CH}_{2}$ & $N D$ & 0.78 & 6.3 & 0.78 & 1.6 & 0.78 & 1.6 & 0.78 \\
\hline $6 w$ & $\mathrm{O} \quad \mathrm{CH}_{2}$ & $-N D$ & 2.0 & 3.9 & 1.0 & 3.1 & 3.9 & 7.8 & 2.0 \\
\hline $6 x$ & $\mathrm{CH}_{2} \mathrm{O}$ & $E N$ & 3.1 & n.d. ${ }^{b}$ & 0.39 & n.d. ${ }^{b}$ & 12.5 & 12.5 & 3.1 \\
\hline $6 y$ & $\mathrm{~S} \quad \mathrm{CH}_{2}$ & $\$ N O$ & 2.0 & 31.3 & 2.0 & n.d. ${ }^{b}$ & 2.0 & 3.9 & 2.0 \\
\hline $6 \mathrm{z}$ & $\mathrm{CH}_{2} \mathrm{CH}_{2}$ & $\mathrm{~A}_{\mathrm{A}} \sim \mathrm{OMe}^{-1}$ & 0.78 & 3.1 & 0.50 & 1.6 & 1.6 & 1.0 & 0.78 \\
\hline 6аa & $\mathrm{O} \quad \mathrm{CH}_{2}$ & ${ }_{A} \sim \mathrm{OMe}^{-}$ & 2.0 & 15.6 & 0.50 & n.d. ${ }^{b}$ & 7.8 & 7.8 & 2.0 \\
\hline $6 \mathrm{bb}$ & $\mathrm{CH}_{2} \mathrm{CH}_{2}$ & ${ }_{\mathrm{H}} \sim \mathrm{NM}_{2}$ & 3.9 & 15.6 & 0.50 & n.d. ${ }^{b}$ & 15.6 & 62.5 & 2.0 \\
\hline $6 \mathrm{cc}$ & $\mathrm{O} \quad \mathrm{CH}_{2}$ & ${ }_{\mathrm{H}} \sim \mathrm{NM}_{2}$ & $>62.5$ & 62.5 & 7.8 & n.d. ${ }^{b}$ & $>62.5$ & $>62.5$ & 31.3 \\
\hline $6 \mathrm{dd}$ & $\mathrm{CH}_{2} \mathrm{CH}_{2}$ & in COMP & 1.6 & 3.1 & 2.0 & n.d. ${ }^{b}$ & 3.1 & 3.1 & 3.1 \\
\hline 6ee & $\mathrm{O} \quad \mathrm{CH}_{2}$ & ${ }_{\mathrm{N}} \mathrm{N} \mathrm{O}^{\mathrm{OMe}}$ & 3.9 & 7.8 & 2.0 & n.d. ${ }^{b}$ & 3.9 & 7.8 & 15.6 \\
\hline iprofloxacir & & & 0.012 & 0.012 & $>250$ & $>250$ & 0.19 & $>25$ & 0.19 \\
\hline
\end{tabular}

${ }^{a}$ Minimum inhibitory concentration. E. coli ${ }^{\mathrm{p}}=$ E. coli BAS849; E. coli ${ }^{\mathrm{WT}}$ =E. coli ATCC 25922;E. coli ${ }^{\mathrm{R} 1}=$ E. coli SKM18; E. coli ${ }^{\mathrm{R} 2}=$ E. coli ELZ4251; $A$. $b_{a u}{ }^{\mathrm{WT}}=A$. baumannii ATCC BAA-747; $A . b_{a u}^{\mathrm{R}}=A$. baumannii MMX2240; K. pneu $^{\mathrm{WT}}=K$. pneumoniae ATCC 35657. ${ }^{b}$ Not determined.

which confer significant resistance to the fluoroquinolones. ${ }^{25}$ For 6a, there was a minimal shift in activity against DNA gyrase $^{\mathrm{WT}}$ compared to the DNA gyrase ${ }^{\mathrm{SD}-\mathrm{LY}}$, with $\mathrm{IC}_{50}$ values of 0.56 and $0.76 \mu \mathrm{M}$, respectively (Table 5). Ciprofloxacin

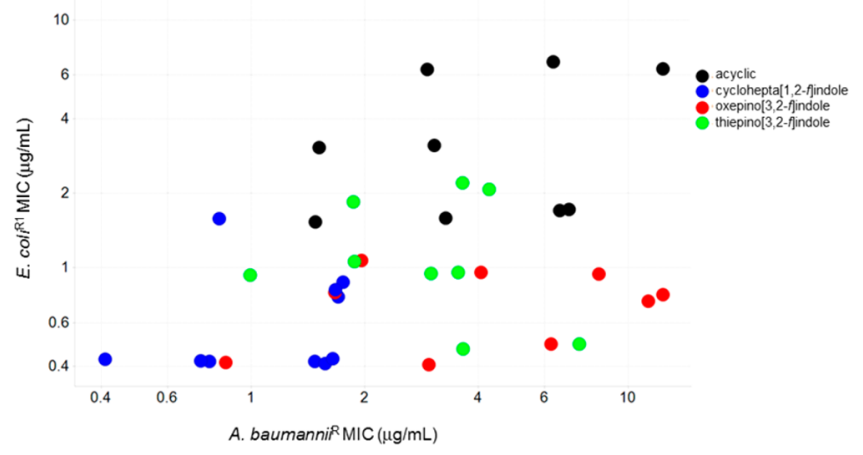

Figure 4. Spotfire plot comparing activities of acyclic 5-indolyl series and three fused series containing different amine fragments against $E$. coli SKM18 (E. coli ${ }^{\mathrm{R} 1}$ ) and A. baumannii MMX2240 (A. baumannii ${ }^{\mathrm{R}}$ ).

exhibited a greater than 13 -fold reduction in activity $\left(\mathrm{IC}_{50}=\right.$ $2.6 \mu \mathrm{M})$ against DNA gyrase ${ }^{\mathrm{SD}-\mathrm{LY}}$ compared to DNA gyrase $\mathrm{e}^{\mathrm{WT}}$ $\left(\mathrm{IC}_{50}=0.19 \mu \mathrm{M}\right)$. There was a good correlation with the activity against the E. coli DNA gyrases and antibacterial activity. MIC values against wild-type E. coli strain 1609 (E. coli $\left.^{\mathrm{WT} 2}\right)^{9}$ and $E$. coli containing the S83L and D87Y GyrA mutations, SKM11 (E. coli $\left.{ }^{\mathrm{R} 3}\right),{ }^{24}$ were both $1.6 \mu \mathrm{g} / \mathrm{mL}$, reflecting the similar $\mathrm{IC}_{50}$ values against both gyrases (Table $5)$. The reduced activity against DNA gyrase ${ }^{\mathrm{SD}-L Y}$ for ciprofloxacin is consistent with the 32 -fold increase in MIC observed against E. coli ${ }^{\mathrm{R} 3}$, which contains both mutations in GyrA. E. coli SKM18 (E. coli ${ }^{\mathrm{R} 1}$ ) is an isogenic construct that contains, in addition to S83L and D87Y, two additional mutations in Topo IV that confer resistance to fluoroquinolones (S80L and E84G). Against E. coli ${ }^{\mathrm{R} 1}$, 6a displayed a 4-fold decrease in MIC, while these additional mutations in the QRDR confer a $\sim 250$-fold increase in MIC for ciprofloxacin.

Susceptibility Testing. Several representative compounds with favorable MIC profiles from the cyclohepta[1,2-f]indole $(6 \mathbf{6}, 6 \mathbf{i}, 6 \mathbf{r}$, and $6 \mathbf{v})$ and oxepino[3,2-f]indole $(6 \mathbf{0}, \mathbf{6 q}, \mathbf{6 s}$, and 6w) series were selected for susceptibility testing against a panel of $12 \mathrm{E}$. coli and $12 \mathrm{~A}$. baumannii isolates to determine abbreviated $\mathrm{MIC}_{50}$ and $\mathrm{MIC}_{90}$ values (Table 6). ${ }^{33}$ The panel contained clinical isolates with varying degrees of resistant phenotypes including six highly fluoroquinolone resistant $E$. coli strains, three of which were MDR, and six fluoroquinolone resistant $A$. baumannii strains, three of which were MDR. Greater potency was observed against the E. coli isolates $\left(\mathrm{MIC}_{90}\right.$ values of $0.5-2 \mu \mathrm{g} / \mathrm{mL}$ ) compared to the A. baumannii isolates $\left(\mathrm{MIC}_{90}\right.$ values of 8 to $\left.>16 \mu \mathrm{g} / \mathrm{mL}\right)$. The comparator fluoroquinolone, levofloxacin, exhibited $\mathrm{MIC}_{90}$ values of 32 and $16 \mu \mathrm{g} / \mathrm{mL}$ against the $E$. coli and A. baumannii isolates, respectively. All compounds shown in Table 6 exhibited good activity against E. coli DNA gyrase and Topo IV as well as good selectivity to human topoisomerase II (see Supplemental Table 1).

Pharmacokinetics and Efficacy Screening. Pharmacokinetic parameters were measured for representative compounds from the cyclohepta[1,2-f]indole and oxepino[3,2-f]indole series after intravenous administration to CD-1 mice (Table 7 ). With the exception of $6 \mathbf{i}$, the compounds exhibited similar profiles with moderate clearance $(35-53 \mathrm{~mL} / \mathrm{min} / \mathrm{kg})$ and a large volume of distribution $(7-13 \mathrm{~L} / \mathrm{kg})$ resulting in a terminal half-life of approximately $2-3 \mathrm{~h}$. Compound $\mathbf{6 i}$ exhibited higher clearance, substantially larger volume of distribution, and a longer half-life. These compounds displayed 


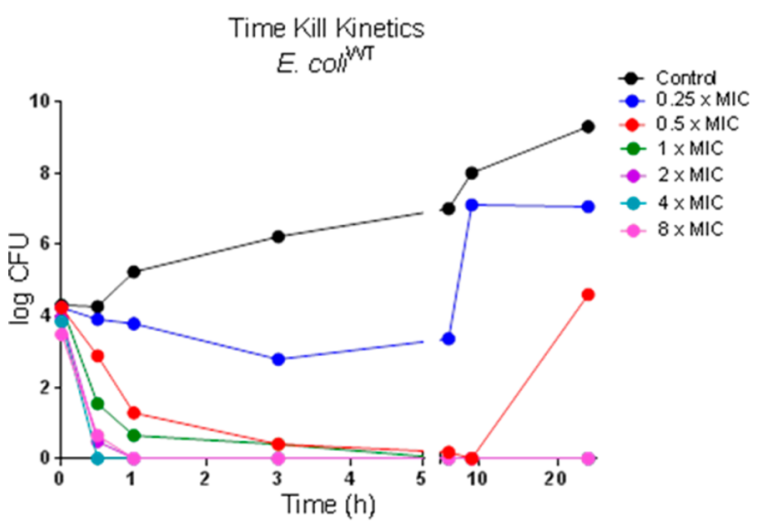

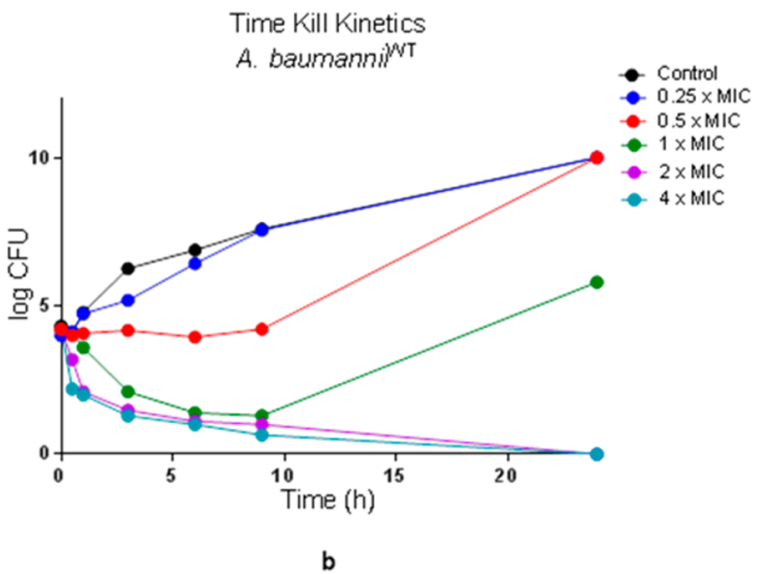

Figure 5. Time-kill kinetics plots for compound $2 \mathbf{m}$ against $E$. coli ${ }^{\mathrm{WT}}(\mathbf{5 a})$ and $A$. baumannii ${ }^{\mathrm{WT}}(\mathbf{5 b})$.

Table 5. E. coli MICs and DNA Gyrase Activity for Compound $6 a$ and Ciprofloxacin

\begin{tabular}{lccccccc} 
& \multicolumn{3}{c}{$\mathrm{MIC}(\mu \mathrm{g} / \mathrm{mL})^{a}$} & & \multicolumn{2}{c}{$\begin{array}{c}\text { E. coli DNA gyrase } \\
\left(\mathrm{IC}_{50}, \mu \mathrm{M}\right)\end{array}$} \\
\cline { 2 - 4 } \multicolumn{1}{c}{ compd } & E. coli $^{\mathrm{WT} 2}$ & E. coli $^{\mathrm{R} 3}$ & E. coli & & gyrase $^{\mathrm{WT}}$ & gyrase $^{\mathrm{SD}-\mathrm{LY}}$ \\
6a & 1.6 & 1.6 & 0.39 & & 0.56 & 0.76 \\
ciprofloxacin & 0.024 & 0.78 & 200 & & 0.19 & 2.6
\end{tabular}

${ }^{a}$ Minimum inhibitory concentration. E. coli ${ }^{\mathrm{WT} 2}=$ E. coli $1609 ;$ E. coli $^{\mathrm{R} 3}$ = E. coli SKM11; E. coli ${ }^{\mathrm{R} 1}=$ E. coli SKM18.

oral bioavailability $(F, \%)$ in the range of $33-60 \%$, which is lower than the oral bioavailability observed for most fluoroquinolones (70-90\%). ${ }^{34}$ Plasma protein binding for these compounds exhibited unbound fractions in mouse plasma $\left(f_{\mathrm{u}}\right)$ of $0.047-0.23$.

The compounds were evaluated for efficacy in a mouse septicemia model (Table 7). Female CD-1 mice were made neutropenic by treatment with cyclophosphamide and then inoculated by intraperitoneal injection with $100 \times$ the $\mathrm{LD}_{50}$ (lethal dose at which $50 \%$ of the mice die) of E. coli ${ }^{\mathrm{WT}}$. The mice were then treated with compounds by intravenous administration at $20 \mathrm{mg} / \mathrm{kg}(n=6$ per group $) 1 \mathrm{~h}$ and again at $5 \mathrm{~h}$ postchallenge (i.e., b.i.d., $40 \mathrm{mg} / \mathrm{kg}$ total). Percent survival was determined at $96 \mathrm{~h}$ postinfection. All compounds with the exception of $6 \mathrm{p}$ showed $>50 \%$ protection. The cyclohepta[1,2-f]indoles $\mathbf{6 r}$ and $\mathbf{6 v}$ and oxepino[3,2-f]indoles 60 and 6 s provided $100 \%$ protection. For these concentrationdependent bactericidal compounds, these results could be rationalized by the free drug concentrations (e.g., free AUC) as a contributor to the PK-PD. For example, the congeners $6 \mathrm{p}$ and $6 \mathrm{q}$ possess equal MICs against E. coli ${ }^{\mathrm{WT}}$ and exhibited nearly identical AUC values, but the 3-fold lower free AUC (resulting from a 3 -fold lower $f_{\mathrm{u}}$ of $\mathbf{6 p}$ compared to $\mathbf{6 q}$ ) is consistent with reduced protection of the former compound. The control compound, moxifloxacin, possesses a lower MIC of $0.024 \mu \mathrm{g} / \mathrm{mL}$ against E. coli ${ }^{W T}$ compared to the 4-hydroxy-2pyridone compounds and showed $100 \%$ protection at a dose of $3 \mathrm{mg} / \mathrm{kg}$ b.i.d. and $83 \%$ protection at a dose of $1.5 \mathrm{mg} / \mathrm{kg}$ b.i.d. Mock treatment resulted in all mice succumbing to infection within $24 \mathrm{~h}$ postinfection.

\section{CONCLUSION}

In summary, the synthesis of a novel series 5-indolyl-4-hydroxy2-pyridones 2, derived from phenyl-substituted 4-hydroxy-2pyridones has been described. These dual targeting bacterial type-II DNA topoisomerase inhibitors primarily target wildtype and resistant Gram-negative bacteria. Further SAR optimization of these compounds was investigated by adding linking groups to restrict rotational freedom between the indole and 2-pyridone rings. The length and placement of the linking groups was found to have a profound effect on antibacterial activity. Evaluation of compounds containing tethers of one to four methylene groups linking the 4-hydroxy-2-pyridone C-5 and the indole C-6 positions revealed that optimal activity was achieved when the linking group comprised three methylene units (seven-membered ring). In this case, the calculated

Table 6. Susceptibility Testing against E. coli and A. baumannii Isolates for Selected Compounds ${ }^{a}$

\begin{tabular}{|c|c|c|c|c|c|c|}
\hline \multirow[b]{2}{*}{ compd } & \multicolumn{3}{|c|}{ E. $\operatorname{coli}(\mu \mathrm{g} / \mathrm{mL})$} & \multicolumn{3}{|c|}{ A. baumannii $(\mu \mathrm{g} / \mathrm{mL})$} \\
\hline & $\mathrm{MIC}_{90}$ & $\mathrm{MIC}_{50}$ & MIC range & $\mathrm{MIC}_{90}$ & $\mathrm{MIC}_{50}$ & MIC range \\
\hline $2 \mathrm{j}$ & 4 & 1 & $0.25-4$ & 16 & 2 & $0.5-32$ \\
\hline $6 a$ & 1 & 1 & $0.25-1$ & 16 & 2 & $0.25-32$ \\
\hline $6 \mathrm{i}$ & 1 & 0.5 & $0.25-1$ & 16 & 2 & $0.25-32$ \\
\hline 60 & 1 & 1 & $0.12-1$ & 8 & 2 & $\leq 0.06$ to $>16$ \\
\hline $6 q$ & 1 & 0.5 & $0.12-1$ & 8 & 1 & $\leq 0.06-16$ \\
\hline $6 r$ & 1 & 0.5 & $0.25-2$ & $>16$ & 2 & $0.12-16$ \\
\hline $6 s$ & 2 & 0.5 & $0.25-8$ & 16 & 2 & 0.25 to $>16$ \\
\hline $6 v$ & 0.5 & 0.5 & $0.12-0.5$ & 16 & 2 & $0.12-16$ \\
\hline $6 w$ & 1 & 0.5 & $0.25-1$ & 8 & 2 & $0.12-16$ \\
\hline levofloxacin & 32 & 0.06 & $0.015-32$ & 16 & 2 & $0.06-64$ \\
\hline
\end{tabular}

${ }^{a}$ Susceptibility testing was performed against 12 strains of E. coli and A. baumannii. See ref 33 for strain information. 
Table 7. Pharmacokinetic Properties, Activity, and in Vivo Efficacy of Selected Compounds

\begin{tabular}{|c|c|c|c|c|c|c|c|c|}
\hline \multirow[b]{2}{*}{ compd } & \multicolumn{5}{|c|}{ pharmacokinetic properties, mouse ${ }^{a}$} & \multirow[b]{2}{*}{$\operatorname{PPB} f_{\mathrm{u}}^{f}$} & \multicolumn{2}{|c|}{ E. $\operatorname{coli}^{\mathrm{WT}}$} \\
\hline & $\mathrm{AUC}_{0-24 \mathrm{~h}}(\mathrm{~h} \cdot \mu \mathrm{g} / \mathrm{mL})$ & $t_{1 / 2}^{b}(\mathrm{~h})$ & $\mathrm{Vd}_{\mathrm{ss}}{ }^{c}(\mathrm{~L} / \mathrm{kg})$ & $\mathrm{Cl}^{d}(\mathrm{~mL} / \mathrm{min} / \mathrm{kg})$ & $F(\%)^{e}$ & & $\operatorname{MIC}^{g}(\mu \mathrm{g} / \mathrm{mL})$ & survival $^{h, i, j}(\%)$ \\
\hline $6 a$ & n.d. ${ }^{k}$ & n.d. ${ }^{k}$ & n.d. ${ }^{k}$ & n.d. ${ }^{k}$ & n.d. ${ }^{k}$ & 0.17 & 0.39 & 83 \\
\hline $6 i$ & 1.81 & 11 & 69 & 64 & 44 & 0.16 & 0.78 & 83 \\
\hline 60 & 3.44 & 2.1 & 7.1 & 48 & 41 & 0.23 & 0.78 & 100 \\
\hline $6 p$ & $4.58^{l}$ & 3.1 & 7.1 & 35 & 65 & 0.047 & 1.0 & 0 \\
\hline $6 q$ & 4.42 & 3.3 & 13 & 37 & 50 & 0.15 & 1.0 & 67 \\
\hline $6 r$ & 3.52 & 2.9 & 11 & 47 & 42 & 0.10 & 0.78 & 100 \\
\hline $6 s$ & $2.93^{l}$ & 3.1 & 7.6 & 53 & n.d. ${ }^{k}$ & 0.21 & 1.0 & 100 \\
\hline $6 v$ & 4.05 & 2.8 & 8.1 & 41 & 33 & 0.11 & 0.78 & 100 \\
\hline $6 w$ & n.d. ${ }^{k}$ & n.d. ${ }^{k}$ & n.d. ${ }^{k}$ & n.d. ${ }^{k}$ & n.d. ${ }^{k}$ & 0.18 & 2.0 & 83 \\
\hline moxifloxacin & $0.64^{m}$ & 1.8 & 3.7 & 72 & n.d. ${ }^{k}$ & 0.80 & 0.024 & $100^{n}$ \\
\hline
\end{tabular}

${ }^{a}$ Compounds were dosed at $10 \mathrm{mg} / \mathrm{kg}$ iv $(n=3)$ in $10 \%$ DMSO and $1 \%$ Tween 80 in pH 8.0 phosphate buffer in CD-1 mice. ${ }^{b}$ Terminal plasma halflife. ${ }^{c}$ Steady-state volume of distribution. ${ }^{d}$ Clearance. ${ }^{e}$ Oral bioavailability. ${ }^{f}$ Mouse plasma protein binding unbound fraction determined by equilibrium dialysis $\left(1 \mu \mathrm{M}\right.$ compound concentration). ${ }^{g}$ Minimum inhibitory concentration against wild-type E. coli (ATCC 25922). ${ }^{h}$ Percent of mice $(n=6)$ surviving $96 \mathrm{~h}$ postinfection after intravenous administration of compound in $3 \% \mathrm{DMSO} / \mathrm{saline.}{ }^{i} \mathrm{Compounds}$ were dosed at $20 \mathrm{mg} / \mathrm{kg}$ at 1 and $5 \mathrm{~h}$ postinfection. ${ }^{j}$ Prior to inoculation with bacteria, mice were made neutropenic with $150 \mathrm{mg} / \mathrm{kg}$ cyclophosphamide (ip) on day -4 and 100 $\mathrm{mg} / \mathrm{kg}$ cyclophosphamide on day -1 (ip). Mice were infected $100 \times \mathrm{LD}_{50}\left(1 \times 10^{6}\right.$ bacteria). ${ }^{k}$ Not determined. ${ }^{2}$ Dosed at $10 \mathrm{mg} / \mathrm{kg}$ iv $(n=3)$ in $20 \%$ (2-hydroxypropyl)- $\beta$-cyclodextrin in pH 4.0 citrate buffer. ${ }^{m}$ Dosed at $3 \mathrm{mg} / \mathrm{kg}$ iv $(n=3)$ in $3 \% \mathrm{DMSO} / \mathrm{saline} .{ }^{n} \mathrm{Dosed}$ at $3 \mathrm{mg} / \mathrm{kg}$ at $1 \mathrm{and} 5 \mathrm{~h}$ postinfection.

dihedral angle for the most energetically stable conformation between the two rings (e.g., 6a) most closely approximated that of the acyclic analog $2 \mathbf{j}$ (135 vs $129^{\circ}$, respectively). Replacement of the methylene group in the tether closest to the indole ring with heteroatoms led to reduced antibacterial activity in the order of $\mathrm{CH}_{2}>\mathrm{O}>\mathrm{S}>\mathrm{N}$. In contrast, connecting a linker of three methylene groups between the 4hydroxy-2-pyridone C-5 and the indole C-4 positions (e.g., 8a) provides similar torsion between the two rings as in $6 \mathbf{a}$, but the significantly altered topology resulted in a dramatic reduction in activity against $E$. coli.

The enhanced activity of the ring constrained 4-hydroxy-2pyridones (i.e., 6a) compared to ciprofloxacin against fluoroquinolone resistant strains could be rationalized by the attenuated shift in activity against $E$. coli DNA gyrase containing mutations in the QRDR at positions S83L and D87Y. Susceptibility testing of compounds $\mathbf{6 o}$ and $\mathbf{6 v}$ showed moderate to good $\mathrm{MIC}_{90}$ values against a panel of clinically relevant resistant phenotypes of E. coli $(0.5$ and $1 \mu \mathrm{g} / \mathrm{mL}$, respectively) and A. baumannii ( 8 and $16 \mu \mathrm{g} / \mathrm{mL}$, respectively). The sterically constrained 4-hydroxy-2-pyridones possess favorable pharmacokinetic properties. Compounds 60 and $6 \mathrm{v}$ were characterized by moderate clearance and moderately high volume of distribution in mice. In a murine septicemia model, both compounds demonstrated complete protection in mice infected with a lethal dose of $E$. coli.

\section{EXPERIMENTAL SECTION}

Starting materials and other reagents were purchased from commercial suppliers and were used without further purification unless otherwise indicated. Air or moisture sensitive reactions were performed under either a nitrogen or argon atmosphere. Flash chromatography was performed using silica gel with standard techniques or with silica gel cartridges on an ISCO Combiflash chromatography instrument. ${ }^{1} \mathrm{H}$ NMR spectra were recorded at $500 \mathrm{MHz}$ on a Bruker NMR spectrometer. The chemical shifts are given in parts per million referenced to the deuterated solvent signal. Coupling constants $(J)$ are recorded in hertz. LC-MS analyses were performed on a Waters Acquity UPLC-MS system with an analytical C18 column, and compounds were detected by UV absorption at $254 \mathrm{~nm}$. All final compounds with reported biological data were determined to be $>95 \%$ pure based on LC-MS and ${ }^{1} \mathrm{H}$ NMR.
5-Ethyl-4-hydroxy-6-(1-methyl-1H-indol-5-yl)-2-oxo-1,2-dihydropyridine-3-carboxylic Acid (2a). To 10a (500 mg, 1.53 $\mathrm{mmol})$ in EtOAc $(5.0 \mathrm{~mL})$ was added lithium iodide $(616 \mathrm{mg}, 4.60$ mmol, 3.0 equiv) at room temperature. The mixture was heated to 65 ${ }^{\circ} \mathrm{C}$ and stirred for $1 \mathrm{~h}$. The reaction mixture was diluted by EtOAc ( 5 $\mathrm{mL})$ and then quenched by $1 \mathrm{~N} \mathrm{HCl}(\sim 2.0 \mathrm{~mL})$. The precipitate was filtered then washed with diethyl ether $(\sim 30 \mathrm{~mL})$ to afford $2 \mathbf{a}$ as a yellow solid (318 mg, 67\%). LC-MS $m / z=313.2[\mathrm{M}+\mathrm{H}]^{+} ;{ }^{1} \mathrm{H}$ NMR (500 MHz, DMSO- $\left.d_{6}\right) \delta 1.00(\mathrm{t}, J=7.41 \mathrm{~Hz}, 3 \mathrm{H}), 2.34(\mathrm{q}, J=$ $7.41 \mathrm{~Hz}, 2 \mathrm{H}), 3.85(\mathrm{~s}, 3 \mathrm{H}), 6.55$ (dd, $J=3.15,0.79 \mathrm{~Hz}, 1 \mathrm{H}), 7.22$ $(\mathrm{dd}, J=8.47,1.69 \mathrm{~Hz}, 1 \mathrm{H}), 7.47(\mathrm{~d}, J=3.07 \mathrm{~Hz}, 1 \mathrm{H}), 7.59(\mathrm{~d}, J=$ $8.51 \mathrm{~Hz}, 1 \mathrm{H}$ ), 7.67 (d, $J=1.18 \mathrm{~Hz}, 1 \mathrm{H}), 12.73$ (br. s, $1 \mathrm{H}$ ), 13.92 (br. s, $1 \mathrm{H})$.

6-(1,2-Dimethyl-1H-indol-5-yl)-5-ethyl-4-hydroxy-2-oxo-1,2dihydropyridine-3-carboxylic Acid (2b). Compound $2 \mathbf{b}$ was prepared from $10 \mathbf{b}$ following the procedure used to prepare $\mathbf{2 a}$ in $54 \%$ yield as an off-white solid. LC-MS $m / z=327.2[\mathrm{M}+\mathrm{H}]^{+}$; ${ }^{1} \mathrm{H}$ $\operatorname{NMR}\left(500 \mathrm{MHz}, \mathrm{DMSO}-d_{6}\right) \delta 0.99(\mathrm{t}, J=7.05 \mathrm{~Hz}, 3 \mathrm{H}), 2.34(\mathrm{~d}, J=$ $7.25 \mathrm{~Hz}, 2 \mathrm{H}), 2.44(\mathrm{~s}, 3 \mathrm{H}), 3.72(\mathrm{~s}, 3 \mathrm{H}), 6.33(\mathrm{~s}, 1 \mathrm{H}), 7.13(\mathrm{~d}, J=$ $7.80 \mathrm{~Hz}, 1 \mathrm{H}$ ), 7.49-7.59 (m, $2 \mathrm{H}), 12.70$ (br. s, $1 \mathrm{H}$ ), 13.90 (br. s, 1 $\mathrm{H})$.

5-Ethyl-4-hydroxy-2-oxo-6-(1,2,3-trimethyl-1H-indol-5-yl)1,2-dihydropyridine-3-carboxylic Acid (2c). Compound 2c was prepared from $10 \mathrm{c}$ following the procedure used to prepare $2 \mathrm{a}$ in $65 \%$ yield as an off-white solid. LC-MS $m / z=341.2[\mathrm{M}+\mathrm{H}]^{+}$; ${ }^{1} \mathrm{H}$ NMR $\left(500 \mathrm{MHz}, \mathrm{DMSO}-d_{6}\right) \delta 1.01(\mathrm{t}, J=7.37 \mathrm{~Hz}, 3 \mathrm{H}), 2.21(\mathrm{~s}, 3 \mathrm{H}), 2.36$ $(\mathrm{q}, J=7.36 \mathrm{~Hz}, 2 \mathrm{H}), 2.37(\mathrm{~s}, 3 \mathrm{H}), 3.70(\mathrm{~s}, 3 \mathrm{H}), 7.14(\mathrm{dd}, J=8.39$, $1.69 \mathrm{~Hz}, 1 \mathrm{H}), 7.43-7.57(\mathrm{~m}, 2 \mathrm{H}), 12.69$ (br. s, $1 \mathrm{H}), 13.90(\mathrm{~s}, 1 \mathrm{H})$.

6-(2-((Dimethylamino)methyl)-1-methyl-1 $\mathrm{H}$-indol-5-yl)-5ethyl-4-hydroxy-2-oxo-1,2-dihydropyridine-3-carboxylic Acid Hydrochloride (2d). Compound $2 \mathrm{~d}$ was prepared from $16 \mathrm{c}$ and dimethylamine according to the procedure used to prepare $2 \mathrm{n}(57 \%)$. LC-MS $m / z=370.2\left[\mathrm{M}+\mathrm{H}^{+}{ }^{+}\right.$; $\mathrm{H}$ NMR $\left(500 \mathrm{MHz}\right.$, methanol- $\left.d_{4}\right) \delta$ $1.06(\mathrm{t}, J=7.28 \mathrm{~Hz}, 3 \mathrm{H}), 2.45(\mathrm{q}, J=7.28 \mathrm{~Hz}, 2 \mathrm{H}), 2.97(\mathrm{~s}, 6 \mathrm{H})$, 3.93 (s, $3 \mathrm{H}), 4.68$ (br. s, $2 \mathrm{H}), 6.95$ (br. s, $1 \mathrm{H}), 7.37$ (d, J = 8.20 Hz, 1 $\mathrm{H}), 7.67(\mathrm{~d}, J=8.51 \mathrm{~Hz}, 1 \mathrm{H}), 7.76(\mathrm{~s}, 1 \mathrm{H})$.

6-(2-((Dimethylamino)methyl)-1-methyl-1H-indol-5-yl)-4hydroxy-2-oxo-1,2-dihydropyridine-3-carboxylic Acid Hydrochloride (2e). Compound 2e was prepared from 16a and dimethylamine according to the procedure used to prepare $2 \mathbf{n}$ (12\%). LC-MS $m / z=342.1[\mathrm{M}+\mathrm{H}]^{+} ;{ }^{1} \mathrm{H}$ NMR (500 MHz, methanol- $\left.d_{4}\right) \delta 2.99$ (br. s, $6 \mathrm{H}$ ), $3.95(\mathrm{~s}, 3 \mathrm{H}), 4.70$ (br. s, $\left.2 \mathrm{H}\right), 6.58$ $(\mathrm{s}, 1 \mathrm{H}), 6.99(\mathrm{~s}, 1 \mathrm{H}), 7.65-7.74(\mathrm{~m}, 3 \mathrm{H})$.

6-(2-((Dimethylamino)methyl)-1-methyl-1H-indol-5-yl)-4hydroxy-5-methyl-2-oxo-1,2-dihydropyridine-3-carboxylic Acid Hydrochloride (2f). Compound $2 \mathrm{f}$ was prepared from $16 \mathrm{~b}$ and 
dimethylamine according to the procedure used to prepare 2 n (24\%). LC-MS $m / z=356.3[\mathrm{M}+\mathrm{H}]^{+} ;{ }^{1} \mathrm{H}$ NMR (500 MHz, methanol- $\left.d_{4}\right) \delta$ 2.01 (s, $3 \mathrm{H}), 2.97$ (s, $6 \mathrm{H}), 3.93$ (s, $3 \mathrm{H}), 4.68$ (br. s, $2 \mathrm{H}), 6.94$ (br. s, $1 \mathrm{H}), 7.39(\mathrm{~d}, J=8.75 \mathrm{~Hz}, 1 \mathrm{H}), 7.68(\mathrm{~d}, J=8.51 \mathrm{~Hz}, 1 \mathrm{H}), 7.79(\mathrm{~s}, 1$ $\mathrm{H})$.

6-(2-((Dimethylamino)methyl)-1-methyl-1 $\mathrm{H}$-indol-5-yl)-4hydroxy-5-isopropyl-2-oxo-1,2-dihydropyridine-3-carboxylic Acid Hydrochloride $(2 \mathrm{~g})$. Compound $2 \mathrm{~g}$ was prepared from $16 \mathrm{~d}$ and dimethylamine according to the procedure used to prepare $2 \mathrm{n}$ (41\%). LC-MS $m / z=382.1[\mathrm{M}-\mathrm{H}]^{-} ;{ }^{1} \mathrm{H}$ NMR $(500 \mathrm{MHz}$, methanol- $\left.d_{4}\right) \delta 1.30(\mathrm{~d}, J=7.09 \mathrm{~Hz}, 6 \mathrm{H}), 2.85-2.94(\mathrm{~m}, 1 \mathrm{H}), 3.00$ $(\mathrm{s}, 6 \mathrm{H}), 3.96(\mathrm{~s}, 3 \mathrm{H}), 4.70(\mathrm{~s}, 2 \mathrm{H}), 6.96(\mathrm{~s}, 1 \mathrm{H}), 7.35(\mathrm{dd}, J=8.55$, $1.69 \mathrm{~Hz}, 1 \mathrm{H}), 7.69$ (d, $J=8.59 \mathrm{~Hz}, 1 \mathrm{H}), 7.73-7.75(\mathrm{~m}, 1 \mathrm{H})$.

5-Cyclopropyl-6-(2-((dimethylamino)methyl)-1-methyl-1 $\mathrm{H}$ indol-5-yl)-4-hydroxy-2-oxo-1,2-dihydropyridine-3-carboxylic Acid Hydrochloride (2h). Compound $2 \mathrm{~h}$ was prepared from $16 \mathrm{e}$ and dimethylamine according to the procedure used to prepare $2 \mathbf{n}$ (30\%). LC-MS $m / z=380.3[\mathrm{M}-\mathrm{H}]^{-} ;{ }^{1} \mathrm{H}$ NMR $(500 \mathrm{MHz}$, methanol- $\left.d_{4}\right) \delta 0.01(\mathrm{dd}, J=5.44,1.34 \mathrm{~Hz}, 2 \mathrm{H}), 0.52(\mathrm{dd}, J=8.39$, $1.54 \mathrm{~Hz}, 2 \mathrm{H}), 1.53-1.62(\mathrm{~m}, 1 \mathrm{H}), 2.87(\mathrm{~s}, 6 \mathrm{H}), 3.83(\mathrm{~s}, 3 \mathrm{H}), 4.57$ $(\mathrm{s}, 2 \mathrm{H}), 6.84(\mathrm{~s}, 1 \mathrm{H}), 7.40(\mathrm{dd}, J=8.59,1.73 \mathrm{~Hz}, 1 \mathrm{H}), 7.54(\mathrm{~d}, J=$ $8.67 \mathrm{~Hz}, 1 \mathrm{H}), 7.76(\mathrm{~d}, J=1.18 \mathrm{~Hz}, 1 \mathrm{H})$.

5-Ethyl-4-hydroxy-6-(1-methyl-2-((methylamino)methyl)$1 H$-indol-5-yl)-2-oxo-1,2-dihydropyridine-3-carboxylic Acid Hydrochloride (2i). Compound $2 \mathrm{i}$ was prepared from $16 \mathrm{c}$ and methylamine according to the procedure used to prepare $2 \mathrm{n}(50 \%)$. LC-MS $m / z=356.3[\mathrm{M}+\mathrm{H}]^{+} ;{ }^{1} \mathrm{H}$ NMR (500 MHz, DMSO- $\left.d_{6}\right) \delta$ $0.98(\mathrm{t}, J=7.37 \mathrm{~Hz}, 3 \mathrm{H}), 2.32(\mathrm{q}, J=7.33 \mathrm{~Hz}, 2 \mathrm{H}), 2.65($ br. s, $3 \mathrm{H})$, $3.86(\mathrm{~s}, 3 \mathrm{H}), 4.44$ (br. s, $2 \mathrm{H}), 6.79(\mathrm{~s}, 1 \mathrm{H}), 7.29(\mathrm{dd}, J=8.51,1.50$ $\mathrm{Hz}, 1 \mathrm{H}), 7.67$ (d, J = 8.43 Hz, $1 \mathrm{H}), 7.74(\mathrm{~s}, 1 \mathrm{H}), 12.78$ (br. s, $1 \mathrm{H}$ ), 13.90 (br. s, $1 \mathrm{H}$ ).

5-Ethyl-6-(2-((ethylamino)methyl)-1-methyl-1H-indol-5-yl)4-hydroxy-2-oxo-1,2-dihydropyridine-3-carboxylic Acid Hydrochloride (2j). Compound $2 \mathrm{j}$ was prepared from $16 \mathrm{c}$ and ethylamine according to the procedure used to prepare $2 \mathrm{n}(48 \%)$. LC-MS $m / z=370.1[\mathrm{M}+\mathrm{H}]^{+} ;{ }^{1} \mathrm{H}$ NMR (500 MHz, DMSO- $\left.d_{6}\right) \delta$ $0.98(\mathrm{t}, J=7.41 \mathrm{~Hz}, 3 \mathrm{H}), 1.28(\mathrm{t}, J=7.25 \mathrm{~Hz}, 3 \mathrm{H}), 2.33(\mathrm{q}, J=7.33$ $\mathrm{Hz}, 2 \mathrm{H}), 2.98-3.13(\mathrm{~m}, 2 \mathrm{H}), 3.87(\mathrm{~s}, 3 \mathrm{H}), 4.43(\mathrm{t}, J=5.12 \mathrm{~Hz}, 2$ $\mathrm{H}), 5.76(\mathrm{~s}, 1 \mathrm{H}), 6.82(\mathrm{~s}, 1 \mathrm{H}), 7.28(\mathrm{dd}, J=8.51,1.66 \mathrm{~Hz}, 1 \mathrm{H}), 7.67$ $(\mathrm{d}, J=8.59 \mathrm{~Hz}, 1 \mathrm{H}), 7.73(\mathrm{~d}, J=1.26 \mathrm{~Hz}, 1 \mathrm{H}), 9.26($ br. s, $2 \mathrm{H})$, $12.79(\mathrm{~s}, 1 \mathrm{H}), 13.90(\mathrm{~s}, 1 \mathrm{H})$.

5-Ethyl-4-hydroxy-6-(2-((isopropylamino)methyl)-1-methyl$1 \mathrm{H}$-indol-5-yl)-2-oxo-1,2-dihydropyridine-3-carboxylic Acid Hydrochloride (2k). Compound $2 \mathrm{k}$ was prepared from $16 \mathrm{c}$ and isopropylamine according to the procedure used to prepare $2 \mathrm{n}(18 \%)$. LC-MS $m / z=384.3[\mathrm{M}+\mathrm{H}]^{+} ;{ }^{1} \mathrm{H}$ NMR (500 MHz, DMSO- $\left.d_{6}\right) \delta$ $0.98(\mathrm{t}, J=7.37 \mathrm{~Hz}, 3 \mathrm{H}), 1.35(\mathrm{~d}, J=7.21 \mathrm{~Hz}, 6 \mathrm{H}), 2.32(\mathrm{q}, J=7.25$ $\mathrm{Hz}, 2 \mathrm{H}), 3.41-3.51(\mathrm{~m}, 1 \mathrm{H}), 3.87(\mathrm{~s}, 3 \mathrm{H}), 4.45(\mathrm{t}, J=5.44 \mathrm{~Hz}, 2$ $\mathrm{H}), 6.81(\mathrm{~s}, 1 \mathrm{H}), 7.28(\mathrm{dd}, J=8.55,1.22 \mathrm{~Hz}, 1 \mathrm{H}), 7.67(\mathrm{~d}, J=8.51$ $\mathrm{Hz}, 1 \mathrm{H}), 7.73$ (s, $1 \mathrm{H}), 9.10$ (br. s, $2 \mathrm{H}), 12.80$ (s, $1 \mathrm{H}), 13.90$ (s, 1 $\mathrm{H})$.

6-(2-((tert-Butylamino)methyl)-1-methyl-1H-indol-5-yl)-5ethyl-4-hydroxy-2-oxo-1,2-dihydropyridine-3-carboxylic Acid Hydrochloride (2l). Compound $2 \mathrm{l}$ was prepared from $16 \mathrm{c}$ and $t$ butylamine according to the procedure used to prepare $2 \mathrm{n}(21 \%)$. LC-MS $m / z=398.4[\mathrm{M}+\mathrm{H}]^{+} ;{ }^{1} \mathrm{H}$ NMR (500 MHz, DMSO- $\left.d_{6}\right) \delta$ $0.98(\mathrm{t}, J=7.37 \mathrm{~Hz}, 3 \mathrm{H}), 1.43(\mathrm{~s}, 9 \mathrm{H}), 2.32(\mathrm{q}, J=7.38 \mathrm{~Hz}, 2 \mathrm{H})$, $3.87(\mathrm{~s}, 3 \mathrm{H}), 4.35-4.47(\mathrm{~m}, 2 \mathrm{H}), 6.83(\mathrm{~s}, 1 \mathrm{H}), 7.28(\mathrm{dd}, J=8.55$, $1.62 \mathrm{~Hz}, 1 \mathrm{H}), 7.68(\mathrm{~d}, J=8.59 \mathrm{~Hz}, 1 \mathrm{H}), 7.74(\mathrm{~d}, J=1.18 \mathrm{~Hz}, 1 \mathrm{H})$, 9.22 (br. s, $2 \mathrm{H}), 12.82$ (s, $1 \mathrm{H}), 13.90$ (s, $1 \mathrm{H})$.

6-(2-(Azetidin-1-ylmethyl)-1-methyl-1H-indol-5-yl)-5-ethyl4-hydroxy-2-oxo-1,2-dihydropyridine-3-carboxylic Acid Hydrochloride $(2 \mathrm{~m})$. Compound $2 \mathrm{~m}$ was prepared from $16 \mathrm{c}$ and azetidine according to the procedure used to prepare $2 \mathrm{n}$ (32\%). LCMS $m / z=382.2[\mathrm{M}+\mathrm{H}]^{+} ;{ }^{1} \mathrm{H}$ NMR $\left(500 \mathrm{MHz}\right.$, methanol- $\left.d_{4}\right) \delta 1.06$ $(\mathrm{t}, J=7.41 \mathrm{~Hz}, 3 \mathrm{H}), 2.44(\mathrm{q}, J=7.38 \mathrm{~Hz}, 2 \mathrm{H}), 2.47-2.56(\mathrm{~m}, 1 \mathrm{H})$, 2.57-2.67 (m, $1 \mathrm{H}), 3.89(\mathrm{~s}, 3 \mathrm{H}), 4.18-4.35(\mathrm{~m}, 4 \mathrm{H}), 4.73(\mathrm{~s}, 2 \mathrm{H})$, $6.85(\mathrm{~s}, 1 \mathrm{H}), 7.34(\mathrm{dd}, J=8.59,1.73 \mathrm{~Hz}, 1 \mathrm{H}), 7.64(\mathrm{~d}, J=8.59 \mathrm{~Hz}, 1$ $\mathrm{H}), 7.73(\mathrm{~d}, J=1.10 \mathrm{~Hz}, 1 \mathrm{H})$.

5-Ethyl-4-hydroxy-6-(1-methyl-2-(pyrrolidin-1-ylmethyl)1H-indol-5-yl)-2-oxo-1,2-dihydropyridine-3-carboxylic Acid
Hydrochloride (2n). To a solution of $16 \mathrm{c}(200 \mathrm{mg}, 0.41 \mathrm{mmol})$ in DCE $(2.0 \mathrm{~mL})$ was added pyrrolidine $(0.07 \mathrm{~mL}, 0.85 \mathrm{mmol}, 2.0$ equiv) and HOAc ( $0.05 \mathrm{~mL}, 0.82 \mathrm{mmol}, 2.0$ equiv) at room temperature. The reaction was stirred for $1 \mathrm{~h}$ before $\mathrm{NaBH}(\mathrm{OAc})_{3}(174 \mathrm{mg}, 0.82 \mathrm{mmol}$, 2.0 equiv) was added. Upon completion of the reaction, the volatiles were removed under reduced pressure followed by the addition of water. The crude product was collected via filtration and purified by preparative HPLC (40-90\% $\mathrm{MeCN}$ in $\mathrm{H}_{2} \mathrm{O}$ ) to afford the reductive amination intermediate. To a suspension of this intermediate in TIPS$\mathrm{H}(1.5 \mathrm{~mL})$ was added TFA $(1.5 \mathrm{~mL})$, and the reaction mixture was heated to $65^{\circ} \mathrm{C}$ for $1 \mathrm{~h}$. Upon completion, the volatiles were removed under reduced pressure. The residue was dissolved in $\mathrm{CH}_{2} \mathrm{Cl}_{2}$ (1.5 $\mathrm{mL})$, then $2 \mathrm{M} \mathrm{HCl} / \mathrm{Et}_{2} \mathrm{O}(2.0 \mathrm{~mL})$ was added. The precipitate was collected by filtration and washed with $\mathrm{Et}_{2} \mathrm{O}(3 \mathrm{~mL} \times 3)$ and then dried under a stream of nitrogen to afford $\mathbf{2 n}$ as a light yellow solid. LC-MS $m / z=396.1[\mathrm{M}+\mathrm{H}]^{+} ;{ }^{1} \mathrm{H}$ NMR $\left(500 \mathrm{MHz}\right.$, methanol- $\left.d_{4}\right) \delta$ $1.04(\mathrm{t}, J=7.25 \mathrm{~Hz}, 3 \mathrm{H}), 1.81-1.86(\mathrm{~m}, 4 \mathrm{H}), 2.41(\mathrm{q}, J=7.57 \mathrm{~Hz}, 2$ H), 2.62-2.67 (m, $4 \mathrm{H}), 3.84(\mathrm{~s}, 3 \mathrm{H}), 3.86(\mathrm{~s}, 2 \mathrm{H}), 6.48(\mathrm{~s}, 1 \mathrm{H})$, $7.18(\mathrm{~d}, J=9.46 \mathrm{~Hz}, 1 \mathrm{H}), 7.45(\mathrm{~d}, J=8.51 \mathrm{~Hz}, 1 \mathrm{H}), 7.55(\mathrm{~s}, 1 \mathrm{H})$.

10-((Ethylamino)methyl)-4-hydroxy-9-methyl-2-oxo$1,2,5,6,7,9$-hexahydropyrido $\left[3^{\prime}, 2^{\prime}: 6,7\right]$ cyclohepta[1,2-f]indole3-carboxylic Acid Hydrochloride (6a). Following the procedure used to prepare $2 \mathrm{n}$, compound $27 \mathrm{c}(126.0 \mathrm{mg}, 0.25 \mathrm{mmol})$ gave $6 \mathrm{a}$ as a pale pink solid $(59.4 \mathrm{mg}, 83 \%)$. LC-MS $m / z=382.1[\mathrm{M}+\mathrm{H}]^{+} ;{ }^{1} \mathrm{H}$ NMR (500 MHz, DMSO-d $\left.d_{6}\right) \delta 1.28(\mathrm{t}, J=7.3 \mathrm{~Hz}, 3 \mathrm{H}$ ), 2.09 (quin, $J$ $=6.3 \mathrm{~Hz}, 2 \mathrm{H}), 2.64-2.77(\mathrm{~m}, 2 \mathrm{H}), 3.06(\mathrm{q}, J=7.3 \mathrm{~Hz}, 2 \mathrm{H}), 3.27-$ $3.44(\mathrm{~m}, 2 \mathrm{H}), 3.85(\mathrm{~s}, 3 \mathrm{H}), 4.39-4.44(\mathrm{~m}, 2 \mathrm{H}), 6.81(\mathrm{~s}, 1 \mathrm{H}), 7.54$ (s, $1 \mathrm{H}), 7.81$ (s, $1 \mathrm{H}), 9.25$ (br. s, $2 \mathrm{H}), 12.89$ (br. s, $1 \mathrm{H}), 13.84$ (br. s, $1 \mathrm{H})$.

4-Hydroxy-9-methyl-10-((methylamino)methyl)-2-oxo$1,2,5,6,7,9$-hexahydropyrido[ $\left.3^{\prime}, 2^{\prime}: 6,7\right]$ cyclohepta[1,2-f]indole3-carboxylic Acid Hydrochloride (6b). Compound $6 \mathrm{~b}$ was prepared from $27 \mathrm{c}$ and a solution of methylamine according to the procedure used to prepare 2 n (44\%, pink solid). LC-MS $m / z=368.8$ $[\mathrm{M}+\mathrm{H}]^{+} ;{ }^{1} \mathrm{H}$ NMR $\left(500 \mathrm{MHz}, \mathrm{DMSO}-d_{6}\right) \delta 2.03-2.22(\mathrm{~m}, 2 \mathrm{H})$, $2.60-2.67(\mathrm{~m}, 3 \mathrm{H}), 2.68-2.78(\mathrm{~m}, 2 \mathrm{H}), 3.27-3.44(\mathrm{~m}, 2 \mathrm{H}), 3.85$ (s, $3 \mathrm{H}), 4.43$ (br. s, $2 \mathrm{H}), 6.80(\mathrm{~s}, 1 \mathrm{H}), 7.55(\mathrm{~s}, 1 \mathrm{H}), 7.82(\mathrm{~s}, 1 \mathrm{H})$, 9.22 (br. s, $2 \mathrm{H}), 12.89$ (s, $1 \mathrm{H}), 13.85$ (br. s, $1 \mathrm{H})$.

4-Hydroxy-9-methyl-10-((methylamino)methyl)-2-oxo2,5,6,9-tetrahydro- $1 H$-pyrido $\left[2^{\prime}, 3^{\prime}: 4,5\right]$ oxepino $[3,2-f]$ indole-3carboxylic Acid Hydrochloride (6c). Following the procedure used to prepare $2 \mathrm{n}$, compound $6 \mathrm{c}$ was obtained from 39 and a solution of methylamine to afford a white solid in 51\% yield. LC-MS $m / z=370.1$ $[\mathrm{M}+\mathrm{H}]^{+} ;{ }^{1} \mathrm{H}$ NMR $\left(500 \mathrm{MHz}, \mathrm{DMSO}-d_{6}\right) \delta 2.63(\mathrm{t}, J=5.20 \mathrm{~Hz}, 5$ $\mathrm{H}), 3.83(\mathrm{~s}, 3 \mathrm{H}), 4.35-4.51(\mathrm{~m}, 4 \mathrm{H}), 6.83(\mathrm{~s}, 1 \mathrm{H}), 7.44(\mathrm{~s}, 1 \mathrm{H})$, $7.86(\mathrm{~s}, 1 \mathrm{H}), 9.33(\mathrm{~d}, J=4.10 \mathrm{~Hz}, 2 \mathrm{H}), 13.04$ (br. s, $1 \mathrm{H}), 13.87$ (s, 1 $\mathrm{H})$.

10-((Ethylamino)methyl)-4-hydroxy-9-methyl-2-oxo-2,5,6,9tetrahydro-1H-pyrido $\left[2^{\prime}, 3^{\prime}: 4,5\right]$ oxepino[3,2-f]indole-3-carboxylic Acid Hydrochloride (6f). Compound $6 \mathrm{f}$ was obtained from 39 and ethylamine to afford a white solid in $31 \%$ yield. LC-MS $\mathrm{m} / z=$ $382.2[\mathrm{M}-\mathrm{H}]^{-} ;{ }^{1} \mathrm{H}$ NMR $\left(500 \mathrm{MHz}, \mathrm{DMSO}-d_{6}\right) \delta 1.29(\mathrm{t}, J=7.17$ $\mathrm{Hz}, 3 \mathrm{H}), 2.63(\mathrm{t}, J=6.03 \mathrm{~Hz}, 2 \mathrm{H}), 3.06(\mathrm{~d}, J=5.44 \mathrm{~Hz}, 2 \mathrm{H}), 3.84(\mathrm{~s}$, $3 \mathrm{H}), 4.35-4.50(\mathrm{~m}, 4 \mathrm{H}), 6.84(\mathrm{~s}, 1 \mathrm{H}), 7.44(\mathrm{~s}, 1 \mathrm{H}), 7.85(\mathrm{~s}, 1 \mathrm{H})$, 9.33 (br. s, $2 \mathrm{H}$ ), 13.05 (br. s, $1 \mathrm{H}), 13.87$ (s, $1 \mathrm{H})$.

4-Hydroxy-10-((isopropylamino)methyl)-9-methyl-2-oxo$1,2,5,6,7,9$-hexahydropyrido $\left[3^{\prime}, 2^{\prime}: 6,7\right]$ cyclohepta[1,2-f]indole3-carboxylic Acid Hydrochloride (6i). Compound 6i was prepared from $27 \mathrm{c}$ and $i$-propylamine according to the procedure used to prepare 2n (43\%, white solid). LC-MS $m / z=394.5[\mathrm{M}-\mathrm{H}]^{-} ;{ }^{1} \mathrm{H}$ NMR $\left(500 \mathrm{MHz}\right.$, DMSO- $\left.d_{6}\right) \delta 1.35(\mathrm{~d}, J=6.3 \mathrm{~Hz}, 6 \mathrm{H}), 2.09$ (quintet, $J=6.5 \mathrm{~Hz}, 2 \mathrm{H}), 2.66-2.76(\mathrm{~m}, 2 \mathrm{H}), 3.27-3.44(\mathrm{~m}, 2 \mathrm{H})$, $3.41-3.49(\mathrm{~m}, 1 \mathrm{H}), 3.85(\mathrm{~s}, 3 \mathrm{H}), 4.43(\mathrm{t}, J=5.5 \mathrm{~Hz}, 2 \mathrm{H}), 6.81(\mathrm{~s}, 1$ H), $7.54(\mathrm{~s}, 1 \mathrm{H}), 7.81(\mathrm{~s}, 1 \mathrm{H}), 9.12$ (br. s, $2 \mathrm{H}), 12.90(\mathrm{~s}, 1 \mathrm{H}), 13.84$ (br. s, $1 \mathrm{H}$ ).

4-Hydroxy-10-((isopropylamino)methyl)-9-methyl-2-oxo2,5,6,9-tetrahydro- $1 H$-pyrido $\left[2^{\prime}, 3^{\prime}: 4,5\right]$ oxepino[3,2-f]indole-3carboxylic Acid Hydrochloride (6j). Compound $6 \mathbf{j}$ was obtained from 39 and isopropylamine to afford a white solid in $27 \%$ yield. LCMS $m / z=396.5[\mathrm{M}-\mathrm{H}]^{-} ;{ }^{1} \mathrm{H}$ NMR (500 MHz, DMSO- $\left.d_{6}\right) \delta 1.36$ $(\mathrm{d}, J=6.54 \mathrm{~Hz}, 6 \mathrm{H}), 2.63(\mathrm{~s}, 2 \mathrm{H}), 3.42-3.51(\mathrm{~m}, 1 \mathrm{H}), 3.83(\mathrm{~s}, 3 \mathrm{H})$, 
4.38-4.49 (m, $4 \mathrm{H}), 6.83$ (s, $1 \mathrm{H}), 7.44$ (s, $1 \mathrm{H}), 7.86$ (s, $1 \mathrm{H}), 9.12-$ $9.23(\mathrm{~m}, 2 \mathrm{H}), 13.01-13.08(\mathrm{~s}, 1 \mathrm{H}), 13.83-13.90(\mathrm{~s}, 1 \mathrm{H})$.

10-((sec-Butylamino)methyl)-4-hydroxy-9-methyl-2-oxo$1,2,5,6,7,9$-hexahydropyrido $\left[3^{\prime}, 2^{\prime}: 6,7\right]$ cyclohepta[1,2-f]indole3-carboxylic Acid Hydrochloride (6n). Compound 6n was prepared from $27 \mathrm{c}$ and $s$-butylamine according to the procedure used to prepare 2n (33\%). LC-MS $m / z=408.3[\mathrm{M}-\mathrm{H}]^{-}$; ${ }^{1} \mathrm{H}$ NMR $\left(500 \mathrm{MHz}, \mathrm{DMSO}-d_{6}\right) \delta 0.94(\mathrm{t}, J=7.4 \mathrm{~Hz}, 3 \mathrm{H}), 1.34(\mathrm{~d}, J=6.3 \mathrm{~Hz}$, $3 \mathrm{H}), 1.51-1.63(\mathrm{~m}, 1 \mathrm{H}), 1.87-1.99(\mathrm{~m}, 1 \mathrm{H}), 2.09$ (quintet, $J=6.4$ $\mathrm{Hz}, 2 \mathrm{H}), 2.63-2.76(\mathrm{~m}, 2 \mathrm{H}), 3.19-3.29(\mathrm{~m}, 1 \mathrm{H}), 3.31-3.36(\mathrm{~m}, 2$ H), $3.85(\mathrm{~s}, 3 \mathrm{H}), 4.44$ (br. s, $2 \mathrm{H}), 6.83(\mathrm{~s}, 1 \mathrm{H}), 7.54(\mathrm{~s}, 1 \mathrm{H}), 7.81$ (s, $1 \mathrm{H}), 9.17$ (br. s, $1 \mathrm{H}), 9.26$ (br. s, $1 \mathrm{H}), 12.90$ (br. s, $1 \mathrm{H}$ ), 13.84 (br. s, $1 \mathrm{H})$.

10-((sec-Butylamino)methyl)-4-hydroxy-9-methyl-2-oxo2,5,6,9-tetrahydro- $1 H$-pyrido[2', 3':4,5] oxepino[3,2-f ]indole-3carboxylic Acid Hydrochloride (60). Compound 60 was obtained from 39 and sec-butylamine to afford a white solid in $57 \%$ yield. LCMS $m / z=410.2[\mathrm{M}-\mathrm{H}]^{-} ;{ }^{1} \mathrm{H}$ NMR (500 MHz, DMSO- $\left.d_{6}\right) \delta 0.95$ $(\mathrm{t}, J=7.41 \mathrm{~Hz}, 3 \mathrm{H}), 1.35(\mathrm{~d}, J=6.62 \mathrm{~Hz}, 3 \mathrm{H}), 1.54-1.64(\mathrm{~m}, 1 \mathrm{H})$, $1.89-2.01(\mathrm{~m}, 1 \mathrm{H}), 2.62(\mathrm{t}, J=6.30 \mathrm{~Hz}, 2 \mathrm{H}), 3.16-3.30(\mathrm{~m}, 1 \mathrm{H})$, $3.84(\mathrm{~s}, 3 \mathrm{H}), 4.36-4.51(\mathrm{~m}, 4 \mathrm{H}), 6.87(\mathrm{~s}, 1 \mathrm{H}), 7.44(\mathrm{~s}, 1 \mathrm{H}), 7.86(\mathrm{~s}$, $1 \mathrm{H}$ ), 9.27 (br. s, $1 \mathrm{H}$ ), 9.38 (br. s, $2 \mathrm{H}$ ), 13.05 (br. s, $1 \mathrm{H}$ ), 13.88 (br. s, $1 \mathrm{H})$.

4-Hydroxy-9-methyl-10-(((1-methylcyclobutyl)amino)methyl)-2-oxo-1,2,5,6,7,9-hexahydropyrido $\left[3^{\prime}, 2^{\prime}: 6,7\right]$ cyclohepta[1,2-f]indole-3-carboxylic Acid Hydrochloride (6p). Compound $6 \mathrm{p}$ was prepared from $27 \mathrm{c}$ and (1-methylcyclobutyl)amine according to the procedure used to prepare $2 \mathrm{n}$ (53\%, yellow solid). LC-MS $m / z=422.2[\mathrm{M}+\mathrm{H}]^{+} ;{ }^{1} \mathrm{H}$ NMR $\left(500 \mathrm{MHz}\right.$, DMSO- $\left.d_{6}\right) \delta$ $1.61(\mathrm{~s}, 3 \mathrm{H}), 1.77-2.00(\mathrm{~m}, 4 \mathrm{H}), 2.09$ (quintet, $J=6.6 \mathrm{~Hz}, 2 \mathrm{H}$ ), 2.51-2.57 (m, $2 \mathrm{H}), 2.71$ (br. s, $2 \mathrm{H}), 3.29-3.37(\mathrm{~m}, 2 \mathrm{H}), 3.86$ (s, 3 H), 4.30 (br. s, $2 \mathrm{H}), 6.82(\mathrm{~s}, 1 \mathrm{H}), 7.55(\mathrm{~s}, 1 \mathrm{H}), 7.81(\mathrm{~s}, 1 \mathrm{H}), 9.59$ (br. s, $2 \mathrm{H}$ ), 12.91 (br. s, $1 \mathrm{H}), 13.84$ (br. s, $1 \mathrm{H}$ ), 16.37 (br. s, $1 \mathrm{H}$ ).

4-Hydroxy-9-methyl-10-(((1-methylcyclobutyl)amino)methyl)-2-oxo-2,5,6,9-tetrahydro- $1 H$-pyrido $\left[2^{\prime}, 3^{\prime}: 4,5\right]$ oxepino[3,2-f] indole-3-carboxylic Acid Hydrochloride (6q). Compound 6q was obtained from 39 and 1-methyl(cyclobutyl)amine to afford a white solid in $47 \%$ yield. LC-MS $m / z=422.2[\mathrm{M}-\mathrm{H}]^{-} ;{ }^{1} \mathrm{H}$ NMR $\left(500 \mathrm{MHz}, \mathrm{DMSO}-d_{6}\right) \delta \mathrm{ppm} 1.60(\mathrm{~s}, 3 \mathrm{H}), 1.80-2.00(\mathrm{~m}, 6 \mathrm{H})$, $2.58-2.66(\mathrm{~m}, 2 \mathrm{H}), 3.84(\mathrm{~s}, 3 \mathrm{H}), 4.28(\mathrm{t}, J=5.48 \mathrm{~Hz}, 2 \mathrm{H}), 4.44(\mathrm{t}, J$ $=6.42 \mathrm{~Hz}, 2 \mathrm{H}), 6.84(\mathrm{~s}, 1 \mathrm{H}), 7.43(\mathrm{~s}, 1 \mathrm{H}), 7.85(\mathrm{~s}, 1 \mathrm{H}), 9.68$ (br. $\mathrm{s}$, $2 \mathrm{H}), 13.05$ (br. s, $1 \mathrm{H}), 13.86$ (br. s, $1 \mathrm{H})$.

10-((Dimethylamino)methyl)-4-hydroxy-9-methyl-2-oxo$1,2,5,6,7,9$-hexahydropyrido $\left[3^{\prime}, 2^{\prime}: 6,7\right]$ cyclohepta[1,2-f]indole3-carboxylic Acid Hydrochloride (6r). Compound $6 r$ was prepared from $27 \mathrm{c}$ and a solution of dimethylamine according to the procedure used to prepare 2 n (53\%, yellow solid). LC-MS $m / z=382.1[\mathrm{M}+$ $\mathrm{H}]^{+} ;{ }^{1} \mathrm{H}$ NMR $\left(500 \mathrm{MHz}\right.$, DMSO- $\left.d_{6}\right) \delta 2.09(\mathrm{t}, J=6.62 \mathrm{~Hz}, 2 \mathrm{H})$, 2.45-2.57 (m, $2 \mathrm{H}), 2.71$ (br. s, $2 \mathrm{H}), 2.79(\mathrm{~s}, 6 \mathrm{H}), 3.88(\mathrm{~s}, 3 \mathrm{H}), 4.58$ (s, $2 \mathrm{H}), 6.89(\mathrm{~s}, 1 \mathrm{H}), 7.56(\mathrm{~s}, 1 \mathrm{H}), 7.84(\mathrm{~s}, 1 \mathrm{H}), 10.53$ (br. s, $1 \mathrm{H})$, 12.89 (br. s, $1 \mathrm{H}), 13.85$ (s, $1 \mathrm{H})$

10-((Dimethylamino)methyl)-4-hydroxy-9-methyl-2-oxo2,5,6,9-tetrahydro-1H-pyrido[ $\left.2^{\prime}, 3^{\prime}: 4,5\right]$ oxepino[3,2-f] indole-3carboxylic Acid Hydrochloride (6s). Compound $6 \mathrm{~s}$ was obtained from 39 and a solution of dimethylamine to afford a white solid in $72 \%$ yield. LC-MS $m / z=382.2[\mathrm{M}-\mathrm{H}]^{-}$; ${ }^{1} \mathrm{H}$ NMR (500 MHz, DMSO$\left.d_{6}\right) \delta 2.61-2.66(\mathrm{~m}, 2 \mathrm{H}), 2.81(\mathrm{~s}, 6 \mathrm{H}), 3.86(\mathrm{~s}, 3 \mathrm{H}), 4.40-4.51(\mathrm{~m}$, $2 \mathrm{H}), 4.51-4.63(\mathrm{~m}, 2 \mathrm{H}), 6.80-7.02(\mathrm{~m}, 1 \mathrm{H}), 7.43-7.52(\mathrm{~m}, 1 \mathrm{H})$, $7.89(\mathrm{~s}, 1 \mathrm{H}), 10.30-10.59$ (br. s, $1 \mathrm{H}), 12.85-13.21($ br. s, $1 \mathrm{H})$, $13.68-14.11$ (br. s, $1 \mathrm{H}$ ).

4-Hydroxy-9-methyl-2-oxo-10-(pyrrolidin-1-ylmethyl)$1,2,5,6,7,9$-hexahydropyrido $\left[3^{\prime}, 2^{\prime}: 6,7\right]$ cyclohepta[1,2-f]indole3-carboxylic Acid Hydrochloride (6v). Compound 6v was prepared from $27 \mathrm{c}$ and pyrrolidine according to the procedure used to prepare $2 \mathrm{n}\left(51 \%\right.$, white solid). $\mathrm{LC}-\mathrm{MS} m / z=408.2[\mathrm{M}+\mathrm{H}]^{+} ;{ }^{1} \mathrm{H}$ NMR $\left(500 \mathrm{MHz}\right.$, DMSO- $\left.d_{6}\right) \delta 1.85-2.00(\mathrm{~m}, 2 \mathrm{H}), 2.00-2.15(\mathrm{~m}, 4$ $\mathrm{H}), 2.48-2.55(\mathrm{~m}, 2 \mathrm{H}), 2.65-2.77(\mathrm{~m}, 2 \mathrm{H}), 3.14-3.23(\mathrm{~m}, 2 \mathrm{H})$, 3.43-3.54 (m, $2 \mathrm{H}), 3.90$ (s, $3 \mathrm{H}), 4.67$ (br. s, $2 \mathrm{H}), 6.91$ (br. s, $1 \mathrm{H}$ ), $7.56(\mathrm{~s}, 1 \mathrm{H}), 7.82(\mathrm{~s}, 1 \mathrm{H}), 10.70$ (br. s, $1 \mathrm{H}), 12.89$ (br. s, $1 \mathrm{H}), 13.85$ $(\mathrm{s}, 1 \mathrm{H})$.
4-Hydroxy-9-methyl-2-oxo-10-(pyrrolidin-1-ylmethyl)2,5,6,9-tetrahydro-1H-pyrido $\left[2^{\prime}, 3^{\prime}: 4,5\right]$ oxepino[3,2-f $]$ indole-3carboxylic Acid Hydrochloride (6w). Compound $6 \mathrm{w}$ was obtained from 39 and pyrrolidine to afford a white solid in $17 \%$ yield. LC-MS $m / z=408.3[\mathrm{M}-\mathrm{H}]^{-} ;{ }^{1} \mathrm{H}$ NMR $\left(500 \mathrm{MHz}, \mathrm{DMSO}-d_{6}\right) \delta 1.85-2.14$ (m, $4 \mathrm{H}), 2.60-2.69(\mathrm{~m}, 4 \mathrm{H}), 3.87(\mathrm{~s}, 3 \mathrm{H}), 4.37-4.55(\mathrm{~m}, 4 \mathrm{H})$, 4.58-4.73 (m, $2 \mathrm{H}), 6.90-6.95(\mathrm{~s}, 1 \mathrm{H}), 7.42-7.49(\mathrm{~s}, 1 \mathrm{H}), 7.83-$ $7.91(\mathrm{~s}, 1 \mathrm{H}), 10.50-10.73$ (br. s, $1 \mathrm{H}), 12.92-13.16$ (br. s, $1 \mathrm{H}$ ), 13.81-13.99 (br. s, $1 \mathrm{H}$ ).

4-Hydroxy-10-(((2-methoxyethyl)amino)methyl)-9-methyl2-oxo-1,2,5,6,7,9-hexahydropyrido $\left[3^{\prime}, 2^{\prime}: 6,7\right]$ cyclohepta[1,2-f]indole-3-carboxylic Acid Hydrochloride (6z). Compound $6 \mathrm{z}$ was prepared from $27 \mathrm{c}$ and (2-methoxyethyl)amine according to the procedure used to prepare $2 \mathrm{n}(41 \%)$. LC-MS $m / z=410.3[\mathrm{M}-$ $\mathrm{H}]^{-}$; ${ }^{1} \mathrm{H}$ NMR $\left(500 \mathrm{MHz}, \mathrm{DMSO}-d_{6}\right) \delta 2.09$ (quintettet, $J=6.6 \mathrm{~Hz}, 2$ $\mathrm{H}), 2.64-2.77(\mathrm{~m}, 2 \mathrm{H}), 3.18-3.22(\mathrm{~m}, 2 \mathrm{H}), 3.31-3.40(\mathrm{~m}, 2 \mathrm{H})$, $3.33(\mathrm{~s}, 3 \mathrm{H}), 3.68(\mathrm{t}, J=5.2 \mathrm{~Hz}, 2 \mathrm{H}), 3.84(\mathrm{~s}, 3 \mathrm{H}), 4.44$ (br. s, $2 \mathrm{H})$, $6.83(\mathrm{~s}, 1 \mathrm{H}), 7.54(\mathrm{~s}, 1 \mathrm{H}), 7.81(\mathrm{~s}, 1 \mathrm{H}), 9.42$ (br. s, $2 \mathrm{H}), 12.89$ (br. s, $1 \mathrm{H}), 13.84$ (br. s, $1 \mathrm{H}$ ).

4-Hydroxy-10-(((2-methoxyethyl)amino)methyl)-9-methyl2-oxo-2,5,6,9-tetrahydro-1H-pyrido[ $\left.2^{\prime}, 3^{\prime}: 4,5\right]$ oxepino[3,2-f]indole-3-carboxylic Acid Hydrochloride (6aa). Compound 6aa was obtained from 39 and 2-methoxyethylamine to afford an off-white solid in $58 \%$ yield. $\mathrm{LC}-\mathrm{MS} m / z=414.3[\mathrm{M}+\mathrm{H}]^{+}, 412.3[\mathrm{M}-\mathrm{H}]^{-}$; ${ }^{1} \mathrm{H}$ NMR $\left(500 \mathrm{MHz}, \mathrm{DMSO}-d_{6}\right) \delta 2.62(\mathrm{t}, J=6.31 \mathrm{~Hz}, 2 \mathrm{H}), 3.13-$ $3.24(\mathrm{~m}, 2 \mathrm{H}), 3.33(\mathrm{~s}, 3 \mathrm{H}), 3.60-3.72(\mathrm{~m}, 2 \mathrm{H}), 3.82(\mathrm{~s}, 3 \mathrm{H}), 4.43$ (br. s, $2 \mathrm{H}), 4.44(\mathrm{t}, J=6.31 \mathrm{~Hz}, 2 \mathrm{H}), 6.85(\mathrm{~s}, 1 \mathrm{H}), 7.42(\mathrm{~s}, 1 \mathrm{H})$, 7.85 (s, 1 H), 9.39 (br. s, 2 H), 13.03 (br. s, 1 H), 13.87 (br. s, 1 H).

10-(((2-(Dimethylamino)ethyl)amino)methyl)-4-hydroxy-9methyl-2-oxo-1, 2, 5,6,7,9-hexahydropyrido $\left[3^{\prime}, 2^{\prime}: 6,7\right]-$ cyclohepta[1,2-f]indole-3-carboxylic Acid Dihydrochloride (6bb). Compound $6 \mathbf{b b}$ was prepared from $27 \mathbf{c}$ and (2(dimethylamino)ethyl)amine according to the procedure used to prepare 2n (28\%). LC-MS $m / z=425.3[\mathrm{M}+\mathrm{H}]^{+}$; ${ }^{1} \mathrm{H}$ NMR (500 MHz, DMSO- $\left.d_{6}\right) \delta 2.02-2.15(\mathrm{~m}, 2 \mathrm{H}), 2.64-2.77(\mathrm{~m}, 2 \mathrm{H}), 2.85(\mathrm{~s}$, $6 \mathrm{H}), 3.28-3.34(\mathrm{~m}, 2 \mathrm{H}), 3.52(\mathrm{~s}, 4 \mathrm{H}), 3.88(\mathrm{~s}, 3 \mathrm{H}), 4.50(\mathrm{~s}, 2 \mathrm{H})$, $6.87(\mathrm{~s}, 1 \mathrm{H}), 7.55(\mathrm{~s}, 1 \mathrm{H}), 7.81(\mathrm{~s}, 1 \mathrm{H}), 9.86($ br. s, $1 \mathrm{H}), 10.87$ (br. s, $1 \mathrm{H}), 12.90$ (br. s, $1 \mathrm{H}$ ), 13.85 (br. s, $1 \mathrm{H}$ ).

10-(((2-(Dimethylamino)ethyl)amino)methyl)-4-hydroxy-9methyl-2-oxo-2,5,6,9-tetrahydro- $1 H$-pyrido $\left[2^{\prime}, 3^{\prime}: 4,5\right]$ oxepino[3,2-f]indole-3-carboxylic Acid Dihydrochloride (6cc). Compound $6 \mathrm{cc}$ was obtained from 39 and 2-(dimethylamino)ethylamine. LC-MS $m / z=427.3[\mathrm{M}+\mathrm{H}]^{+}, 425.2[\mathrm{M}-\mathrm{H}]^{-} ;{ }^{1} \mathrm{H}$ NMR $(500$ $\left.\mathrm{MHz}, \mathrm{DMSO}-d_{6}\right) \delta 2.62(\mathrm{t}, J=6.3 \mathrm{~Hz}, 2 \mathrm{H}), 2.85(\mathrm{~s}, 6 \mathrm{H}), 3.37-3.55$ $(\mathrm{m}, 4 \mathrm{H}), 3.85(\mathrm{~s}, 3 \mathrm{H}), 4.45(\mathrm{t}, J=6.3 \mathrm{~Hz}, 2 \mathrm{H}), 4.49$ (br. s, $2 \mathrm{H})$, $6.87(\mathrm{~s}, 1 \mathrm{H}), 7.44(\mathrm{~s}, 1 \mathrm{H}), 7.86(\mathrm{~s}, 1 \mathrm{H}), 9.75$ (br. s, $2 \mathrm{H}), 10.68$ (br. s, $1 \mathrm{H}$ ), 13.02 (br. s, $1 \mathrm{H}$ ), 13.87 (br. s, $1 \mathrm{H}$ ).

4-Hydroxy-10-((3-methoxypyrrolidin-1-yl)methyl)-9-methyl2-oxo-1,2,5,6,7,9-hexahydropyrido[3',2':6,7]cyclohepta[1,2-f]indole-3-carboxylic Acid Hydrochloride (6dd). Compound 6dd was prepared from $27 \mathrm{c}$ and 3-methoxypyrrolidine according to the procedure used to prepare $2 \mathrm{n}(45 \%)$. LC-MS $m / z=438.3[\mathrm{M}+\mathrm{H}]^{+}$; ${ }^{1} \mathrm{H}$ NMR $\left(500 \mathrm{MHz}, \mathrm{DMSO}-d_{6}\right) \delta 1.91-2.24(\mathrm{~m}, 4 \mathrm{H}), 2.65-2.79$ $(\mathrm{m}, 2 \mathrm{H}), 3.21-3.33(\mathrm{~m}, 4 \mathrm{H}), 3.38(\mathrm{~s}, 3 \mathrm{H}), 3.47-3.75(\mathrm{~m}, 2 \mathrm{H}), 3.86$ (s, $3 \mathrm{H}), 4.07-4.25(\mathrm{~m}, 1 \mathrm{H}), 4.66$ (br. s, $2 \mathrm{H}), 6.91(\mathrm{~s}, 1 \mathrm{H}), 7.55$ (s, $1 \mathrm{H}), 7.82(\mathrm{~s}, 1 \mathrm{H}), 10.52-11.14(\mathrm{~m}, 1 \mathrm{H}), 12.88$ (br. s, $1 \mathrm{H}), 13.85$ (s, $1 \mathrm{H})$.

4-Hydroxy-10-((3-methoxypyrrolidin-1-yl)methyl)-9-methyl2-oxo-2,5,6,9-tetrahydro-1 $H$-pyrido $\left[2^{\prime}, 3^{\prime}: 4,5\right]$ oxepino[3,2-f]indole-3-carboxylic Acid Hydrochloride (6ee). Compound 6ee was obtained from 39 and 3-methoxypyrrolidine to afford a white solid in $49 \%$ yield. $\mathrm{LC}-\mathrm{MS} m / z=440.1[\mathrm{M}+\mathrm{H}]^{+} ;{ }^{1} \mathrm{H}$ NMR $(500 \mathrm{MHz}$, DMSO- $\left.d_{6}\right) \delta 2.64(\mathrm{~m}, 2 \mathrm{H}), 3.28-3.41(\mathrm{~m}, 7 \mathrm{H}), 3.48-3.65(\mathrm{~m}, 2 \mathrm{H})$, $3.81-3.94(\mathrm{~m}, 3 \mathrm{H}), 4.39-4.54(\mathrm{~m}, 3 \mathrm{H}), 4.60-4.77(\mathrm{~m}, 2 \mathrm{H}), 6.95(\mathrm{~s}$, $1 \mathrm{H}), 7.44(\mathrm{~s}, 1 \mathrm{H}), 7.87$ (s, 1H), 13.03 (br. s, $1 \mathrm{H}), 13.88$ (br. s, $1 \mathrm{H})$.

1-(1-Methyl-1H-indol-5-yl)butan-1-one (9a). To a solution of 5-bromo-1-methyl- $1 \mathrm{H}$-indole $(9.8 \mathrm{~g}, 46.7 \mathrm{mmol})$ in THF $(40 \mathrm{~mL})$ was added $n$-BuLi (2.5 M in hexanes, $22.3 \mathrm{~mL}, 55.8 \mathrm{mmol}, 1.2$ equiv) at $-78{ }^{\circ} \mathrm{C}$ dropwise over $15 \mathrm{~min}$. The mixture was stirred for $30 \mathrm{~min}$ at $-78{ }^{\circ} \mathrm{C}$ before a solution of $\mathrm{N}$-methoxy- $\mathrm{N}$-methylbutyramide $(7.35 \mathrm{~g}$, $56.0 \mathrm{mmol}, 1.2$ equiv $)$ in THF $(10 \mathrm{~mL})$ was added. After stirring at 
$-78{ }^{\circ} \mathrm{C}$ for $10 \mathrm{~min}$, the reaction was quenched by saturated aq. $\mathrm{NH}_{4} \mathrm{Cl}$. The resulting mixture was extracted by ether $(30 \mathrm{~mL} \times 3)$, and the combined organic layers were dried over $\mathrm{Na}_{2} \mathrm{SO}_{4}$. The crude product was purified by flash chromatography $(0-10 \%$ EtOAc in hexanes) to give $9 \mathrm{a}(5.40 \mathrm{~g}, 26.8 \mathrm{mmol}, 57 \%)$ as a white solid. LC-MS $m / z=202.2[\mathrm{M}+\mathrm{H}]^{+} ;{ }^{1} \mathrm{H}$ NMR $\left(500 \mathrm{MHz}, \mathrm{CDCl}_{3}\right) \delta \mathrm{ppm} 1.04(\mathrm{t}, J$ $=7.45 \mathrm{~Hz}, 3 \mathrm{H}), 1.82$ (sextet, $J=7.39 \mathrm{~Hz}, 2 \mathrm{H}), 3.04(\mathrm{t}, J=7.39 \mathrm{~Hz}, 2$ $\mathrm{H}), 3.84(\mathrm{~s}, 3 \mathrm{H}), 6.62(\mathrm{dd}, J=3.15,0.87 \mathrm{~Hz}, 1 \mathrm{H}), 7.09-7.16(\mathrm{~m}, 1$ $\mathrm{H}), 7.35(\mathrm{~d}, J=8.67 \mathrm{~Hz}, 1 \mathrm{H}), 7.92(\mathrm{dd}, J=8.71,1.69 \mathrm{~Hz}, 1 \mathrm{H}), 8.32$ (dd, $J=1.69,0.51 \mathrm{~Hz}, 1 \mathrm{H})$.

1-(1,2-Dimethyl-1H-indol-5-yl)butan-1-one (9b). Compound 9b was prepared from 5-bromo-1,2-dimethyl- $1 \mathrm{H}$-indole following the procedure used to prepare $9 \mathrm{a}$ in $50 \%$ yield as an off-white solid. ${ }^{1} \mathrm{H}$ $\operatorname{NMR}\left(500 \mathrm{MHz}, \mathrm{CDCl}_{3}\right) \delta 1.03(\mathrm{t}, J=7.41 \mathrm{~Hz}, 3 \mathrm{H}), 1.81$ (sextet, $J=$ $7.44 \mathrm{~Hz}, 2 \mathrm{H}), 2.45(\mathrm{~d}, J=0.95 \mathrm{~Hz}, 3 \mathrm{H}), 2.97-3.08(\mathrm{~m}, 2 \mathrm{H}), 3.70(\mathrm{~s}$, $3 \mathrm{H}), 6.36(\mathrm{t}, J=0.95 \mathrm{~Hz}, 1 \mathrm{H}), 7.22-7.31(\mathrm{~m}, 1 \mathrm{H}), 7.85(\mathrm{dd}, J=$ $8.67,1.73 \mathrm{~Hz}, 1 \mathrm{H}), 8.20(\mathrm{~d}, J=1.58 \mathrm{~Hz}, 1 \mathrm{H})$.

1-(1,2,3-Trimethyl- $1 \mathrm{H}$-indol-5-yl)butan-1-one (9c). Compound $9 \mathrm{c}$ was prepared from 5-bromo-1,2,3-trimethyl- $1 \mathrm{H}$-indole following the procedure used to prepare $9 \mathrm{a}(75 \%)$ as an off-white solid. ${ }^{1} \mathrm{H}$ NMR $\left(500 \mathrm{MHz}, \mathrm{CDCl}_{3}\right) \delta 1.04(\mathrm{t}, J=7.41 \mathrm{~Hz}, 3 \mathrm{H}), 1.82$ (sextet, $J=7.38 \mathrm{~Hz}, 2 \mathrm{H}), 2.30(\mathrm{~s}, 3 \mathrm{H}), 2.37(\mathrm{~s}, 3 \mathrm{H}), 2.99-3.07(\mathrm{~m}$, $2 \mathrm{H}), 3.68(\mathrm{~s}, 3 \mathrm{H}), 7.21-7.26(\mathrm{~m}, 1 \mathrm{H}), 7.84(\mathrm{dd}, J=8.67,1.73 \mathrm{~Hz}, 1$ $\mathrm{H}), 8.18(\mathrm{~d}, J=1.58 \mathrm{~Hz}, 1 \mathrm{H})$.

Methyl 5-Ethyl-4-hydroxy-6-(1-methyl-1 $\mathrm{H}$-indol-5-yl)-2-oxo1,2-dihydropyridine-3-carboxylate (10a). To a solution of 9a $(5.40 \mathrm{~g}, 26.8 \mathrm{mmol})$ in $\mathrm{CH}_{2} \mathrm{Cl}_{2}(30 \mathrm{~mL})$ was added $t$-butylamine $(11.3$ $\mathrm{mL}, 107.1 \mathrm{mmol}, 4.0$ equiv). The mixture was cooled to $0{ }^{\circ} \mathrm{C}$ before $\mathrm{TiCl}_{4}$ (1.0 M in $\mathrm{CH}_{2} \mathrm{Cl}_{2}, 17.4 \mathrm{~mL}, 17.4 \mathrm{mmol}, 0.65$ equiv) was added via syringe pump over $30 \mathrm{~min}$. The reaction was warmed to room temperature and stirred overnight. The reaction mixture was quenched by saturated aq. $\mathrm{NaHCO}_{3}$ solution $(20 \mathrm{~mL})$ then extracted by $\mathrm{CH}_{2} \mathrm{Cl}_{2}$ $(25 \mathrm{~mL} \times 5)$ using a phase separator $(75 \mathrm{~mL})$. The combined organic layers were dried over $\mathrm{Na}_{2} \mathrm{SO}_{4}$ and then concentrated to give $6.70 \mathrm{~g}$ of the imine intermediate ( $\mathrm{LC}-\mathrm{MS} m / z=257.3[\mathrm{M}+\mathrm{H}]^{+}$), which was used directly in the next step without further purification. To a suspension of the imine intermediate $(6.70 \mathrm{~g}, 26.1 \mathrm{mmol})$ in $\mathrm{Ph}_{2} \mathrm{O}(40$ $\mathrm{mL}$ ) was added trimethylmethanetricarboxylate $(8.44 \mathrm{~g}, 44.4 \mathrm{mmol}$, 1.7 equiv). The reaction was heated with stirring at $230{ }^{\circ} \mathrm{C}$ for $10 \mathrm{~min}$, removing the methanol with a distillation apparatus attached to the flask. The mixture was cooled to room temperature, and the precipitate was filtered and then washed with diethyl ether to afford the 10a as a yellow solid ( $4.85 \mathrm{~g}, 14.9 \mathrm{mmol}, 56 \%$ over 2-step). LCMS $m / z=327.2[\mathrm{M}+\mathrm{H}]^{+} ;{ }^{1} \mathrm{H}$ NMR $\left(500 \mathrm{MHz}, \mathrm{CDCl}_{3}\right) \delta 1.14(\mathrm{t}, J$ $=7.33 \mathrm{~Hz}, 3 \mathrm{H}), 2.49(\mathrm{q}, J=7.33 \mathrm{~Hz}, 2 \mathrm{H}), 3.87(\mathrm{~s}, 3 \mathrm{H}), 4.02(\mathrm{~s}, 3$ H), $6.58(\mathrm{dd}, J=3.11,0.83 \mathrm{~Hz}, 1 \mathrm{H}), 7.18(\mathrm{~d}, J=3.07 \mathrm{~Hz}, 1 \mathrm{H}), 7.24$ $(\mathrm{dd}, J=8.47,1.69 \mathrm{~Hz}, 1 \mathrm{H}), 7.44(\mathrm{~d}, J=8.51 \mathrm{~Hz}, 1 \mathrm{H}), 7.68(\mathrm{dd}, J=$ $1.69,0.59 \mathrm{~Hz}, 1 \mathrm{H}), 13.88(\mathrm{~s}, 1 \mathrm{H})$.

Methyl 6-(1,2-Dimethyl-1H-indol-5-yl)-5-ethyl-4-hydroxy-2oxo-1,2-dihydropyridine-3-carboxylate (10b). Compound 10b was prepared from $9 \mathbf{b}$ following the procedure used to prepare $10 \mathrm{a}$ in $27 \%$ yield as an off-white solid. LC-MS $m / z=339.2[\mathrm{M}-\mathrm{H}]^{-}, 341.1$ $[\mathrm{M}+\mathrm{H}]^{+}$

Methyl 5-Ethyl-4-hydroxy-2-oxo-6-(1,2,3-trimethyl-1Hindol-5-yl)-1,2-dihydropyridine-3-carboxylate (10c). Compound $10 \mathrm{c}$ was prepared from $9 \mathrm{c}$ following the procedure used to prepare $10 \mathrm{a}$ in $21 \%$ yield as an off-white solid. ${ }^{1} \mathrm{H}$ NMR $\left(500 \mathrm{MHz}, \mathrm{CDCl}_{3}\right) \delta$ $1.15(\mathrm{t}, J=7.36 \mathrm{~Hz}, 3 \mathrm{H}), 2.28(\mathrm{~s}, 3 \mathrm{H}), 2.39(\mathrm{~s}, 3 \mathrm{H}), 2.53(\mathrm{q}, J=7.36$ $\mathrm{Hz}, 2 \mathrm{H}), 3.71(\mathrm{~s}, 3 \mathrm{H}), 4.02(\mathrm{~s}, 3 \mathrm{H}), 7.18(\mathrm{dd}, J=8.35,1.73 \mathrm{~Hz}, 1$ H), $7.33(\mathrm{~d}, J=8.35 \mathrm{~Hz}, 1 \mathrm{H}), 7.54(\mathrm{~d}, J=1.58 \mathrm{~Hz}, 1 \mathrm{H}), 9.03$ (br. s, 1 $\mathrm{H}), 13.85(\mathrm{~s}, 1 \mathrm{H})$.

5-Bromo-2-((tert-butyldimethylsilyloxy)methyl)-1-methyl$1 H$-indole (11). To a solution of ethyl 5-bromo-1-methyl- $1 H$-indole2-carboxylate $(9.0 \mathrm{~g}, 31.9 \mathrm{mmol})$ in $\mathrm{CH}_{2} \mathrm{Cl}_{2}(80 \mathrm{~mL})$ was added DIBAL-H (1.0 M in hexanes, $70.0 \mathrm{~mL}, 2.2$ equiv) at $-78{ }^{\circ} \mathrm{C}$ over 15 min. After stirring for $1 \mathrm{~h}$ at $-78{ }^{\circ} \mathrm{C}$, the reaction was quenched by the addition of $1 \mathrm{~N} \mathrm{HCl}(20 \mathrm{~mL})$ at $-78{ }^{\circ} \mathrm{C}$ and then warmed to room temperature and stirred for an additional $30 \mathrm{~min}$ to break up the aluminum emulsion. The biphasic mixture was extracted with ether/ EtOAc $(1: 1,50 \mathrm{~mL} \times 3)$. The combined organic layers were dried over $\mathrm{Na}_{2} \mathrm{SO}_{4}$ and then concentrated to give (5-bromo-1-methyl-1Hindol-2-yl)methanol (ca. $7.8 \mathrm{~g}$, quant).

To a solution of (5-bromo-1-methyl-1H-indol-2-yl)methanol ( $7.8 \mathrm{~g}$, ca. $31.3 \mathrm{mmol})$ in $\mathrm{CH}_{2} \mathrm{Cl}_{2}(80 \mathrm{~mL})$ was added imidazole $(2.8 \mathrm{~g}, 40.7$ mmol, 1.3 equiv) followed by TBSCl $(6.1 \mathrm{~g}, 40.7 \mathrm{mmol}, 1.3$ equiv $)$ at 0 ${ }^{\circ} \mathrm{C}$. After $1 \mathrm{~h}$, the reaction was quenched with water and then extracted with $\mathrm{CH}_{2} \mathrm{Cl}_{2}(50 \mathrm{~mL} \times 3)$. The solvent was concentrated to give crude product, which was purified by flash column chromatography $(50 \%$ $\mathrm{CH}_{2} \mathrm{Cl}_{2}$ in hexanes) to afford 11 (10.7 g, 96\% yield over two steps) as an off-white solid. LC-MS $m / z=354.0,356.0[\mathrm{M}+\mathrm{H}]^{+}$; ${ }^{1} \mathrm{H}$ NMR $\left(500 \mathrm{MHz}, \mathrm{CDCl}_{3}\right) \delta 0.07(\mathrm{~s}, 6 \mathrm{H}), 0.90(\mathrm{~s}, 9 \mathrm{H}), 3.77(\mathrm{~s}, 3 \mathrm{H}), 4.79-$ $4.85(\mathrm{~m}, 2 \mathrm{H}), 6.30-6.35(\mathrm{~m}, 1 \mathrm{H}), 7.17(\mathrm{~d}, J=8.67 \mathrm{~Hz}, 1 \mathrm{H}), 7.27-$ $7.31(\mathrm{~m}, 1 \mathrm{H}), 7.69(\mathrm{dd}, J=1.89,0.47 \mathrm{~Hz}, 1 \mathrm{H})$.

1-(2-((tert-Butyldimethylsilyl)oxy)methyl)-1-methyl-1 Hindol-5-yl)ethan-1-one (12a). Compound 12a was prepared from 11 and $N$-methoxy- $N$-methylacetamide in $92 \%$ yield according to the procedure used to prepare $12 \mathrm{c}$. LC-MS $m / z=318.3[\mathrm{M}+\mathrm{H}]^{+}$.

1-(2-((tert-Butyldimethylsilyloxy)methyl)-1-methyl-1 Hindol-5-yl)propan-1-one (12b). Compound $12 \mathrm{~b}$ was prepared from 11 and $\mathrm{N}$-methoxy- $\mathrm{N}$-methylpropionamide in $61 \%$ yield according to the procedure used to prepare $12 \mathrm{c}$. LC-MS $m / z=332.2[\mathrm{M}+\mathrm{H}]^{+}$; ${ }^{1} \mathrm{H}$ NMR $\left(500 \mathrm{MHz}, \mathrm{CDCl}_{3}\right) \delta 0.04-0.10(\mathrm{~m}, 6 \mathrm{H}), 0.88-0.93(\mathrm{~m}, 9$ $\mathrm{H}), 1.26(\mathrm{t}, J=7.29 \mathrm{~Hz}, 3 \mathrm{H}), 3.09(\mathrm{q}, J=7.30 \mathrm{~Hz}, 2 \mathrm{H}), 3.82(\mathrm{~s}, 3 \mathrm{H})$, $4.84(\mathrm{~s}, 2 \mathrm{H}), 6.47-6.53(\mathrm{~m}, 1 \mathrm{H}), 7.33(\mathrm{~d}, J=8.75 \mathrm{~Hz}, 1 \mathrm{H}), 7.91$ $(\mathrm{dd}, J=8.67,1.73 \mathrm{~Hz}, 1 \mathrm{H}), 8.27(\mathrm{~d}, J=1.18 \mathrm{~Hz}, 1 \mathrm{H})$.

1-(2-((tert-Butyldimethylsilyloxy)methyl)-1-methyl-1 Hindol-5-yl)butan-1-one (12c). To a solution of 11 (16.6 g, 46.7 $\mathrm{mmol})$ in THF $(60 \mathrm{~mL})$ was added $n$-BuLi $(2.5 \mathrm{M}$ in hexanes, 22.3 $\mathrm{mL}, 55.8 \mathrm{mmol})$ at $-78{ }^{\circ} \mathrm{C}$ dropwise over $15 \mathrm{~min}$. The mixture was stirred for $30 \mathrm{~min}$ at $-78{ }^{\circ} \mathrm{C}$ before a solution of $\mathrm{N}$-methoxy- $\mathrm{N}$ methylbutyramide $(7.35 \mathrm{~g}, 56.0 \mathrm{mmol})$ in THF $(10 \mathrm{~mL})$ was added. After stirring at $-78{ }^{\circ} \mathrm{C}$ for $10 \mathrm{~min}$, the reaction was quenched with saturated aq. $\mathrm{NH}_{4} \mathrm{Cl}$. The resulting mixture was extracted with ether $(30 \mathrm{~mL} \times 3)$, and the combined organic layers were dried over $\mathrm{Na}_{2} \mathrm{SO}_{4}$. The crude product was purified by flash chromatography (0$10 \%$ EtOAc in hexanes) to give $12 \mathrm{c}(9.3 \mathrm{~g}, 57 \%)$ as a white solid. ${ }^{1} \mathrm{H}$ $\operatorname{NMR}\left(500 \mathrm{MHz}, \mathrm{CDCl}_{3}\right) \delta 0.08(\mathrm{~s}, 6 \mathrm{H}), 0.91(\mathrm{~s}, 9 \mathrm{H}), 1.03(\mathrm{t}, J=$ $7.41 \mathrm{~Hz}, 3 \mathrm{H}), 1.74-1.88(\mathrm{~m}, 2 \mathrm{H}), 2.97-3.07(\mathrm{~m}, 2 \mathrm{H}), 3.82(\mathrm{~s}, 3 \mathrm{H})$ $4.85(\mathrm{~s}, 2 \mathrm{H}), 6.46-6.52(\mathrm{~m}, 1 \mathrm{H}), 7.32(\mathrm{~d}, J=8.67 \mathrm{~Hz}, 1 \mathrm{H}), 7.90$ $(\mathrm{dd}, J=8.67,1.73 \mathrm{~Hz}, 1 \mathrm{H}), 8.26(\mathrm{~d}, J=1.18 \mathrm{~Hz}, 1 \mathrm{H})$.

1-(2-((tert-Butyldimethylsilyl)oxy)methyl)-1-methyl-1 Hindol-5-yl)-3-methylbutan-1-one (12d). Compound 12d was prepared from 11 and $N$-methoxy- $N$-methylisobutyramide in $85 \%$ yield according to the procedure used to prepare $12 \mathrm{c}$. LC-MS $\mathrm{m} / z=$ $360.2[\mathrm{M}+\mathrm{H}]^{+}$.

1-(2-((tert-Butyldimethylsilyl)oxy)methyl)-1-methyl-1 Hindol-5-yl)-2-cyclopropylethan-1-one (12e). Compound 12e was prepared from 11 and $N$-methoxy- $N$-methylcyclopropanecarboxamide in $72 \%$ yield according to the procedure used to prepare $12 \mathrm{c}$. LC-MS $m / z=358.3[\mathrm{M}+\mathrm{H}]^{+}$.

Methyl 6-(2-(((tert-Butyldimethylsilyl)oxy)methyl)-1-methyl$1 H$-indol-5-yl)-1-(2,4-dimethoxybenzyl)-4-hydroxy-2-oxo-1,2dihydropyridine-3-carboxylate (13a). Compound 13a was prepared according to the procedure used to prepare $13 \mathrm{c}$ in $46 \%$ yield. LC-MS $m / z=593.4\left[\mathrm{M}+\mathrm{H}^{+} ;{ }^{1} \mathrm{H}\right.$ NMR $\left(500 \mathrm{MHz}, \mathrm{CDCl}_{3}\right) \delta 0.00$ $(\mathrm{s}, 6 \mathrm{H}), 0.82(\mathrm{~s}, 9 \mathrm{H}), 3.33(\mathrm{~s}, 3 \mathrm{H}), 3.68(\mathrm{~s}, 3 \mathrm{H}), 3.70(\mathrm{~s}, 3 \mathrm{H}), 3.90$ $(\mathrm{s}, 3 \mathrm{H}), 4.74(\mathrm{~s}, 2 \mathrm{H}), 4.96(\mathrm{~s}, 2 \mathrm{H}), 5.92(\mathrm{~s}, 1 \mathrm{H}), 6.17(\mathrm{~d}, J=2.44$ $\mathrm{Hz}, 1 \mathrm{H}), 6.26(\mathrm{~s}, 1 \mathrm{H}), 6.32(\mathrm{dd}, J=8.43,2.36 \mathrm{~Hz}, 1 \mathrm{H}), 6.79(\mathrm{~d}, J=$ $8.43 \mathrm{~Hz}, 1 \mathrm{H}), 6.92(\mathrm{~d}, J=1.73 \mathrm{~Hz}, 1 \mathrm{H}), 7.14(\mathrm{~d}, J=8.59 \mathrm{~Hz}, 1 \mathrm{H})$, 7.29 (d, $J=1.18 \mathrm{~Hz}, 1 \mathrm{H}), 13.19(\mathrm{~s}, 1 \mathrm{H})$.

Methyl 6-(2-((tert-Butyldimethylsilyloxy)methyl)-1-methyl$1 H$-indol-5-yl)-1-(2,4-dimethoxybenzyl)-4-hydroxy-5-methyl2-oxo-1,2-dihydropyridine-3-carboxylate (13b). Compound 13b was prepared according to the procedure used to prepare $13 \mathrm{c}$ in $47 \%$ yield. LC-MS $m / z=607.4[\mathrm{M}+\mathrm{H}]^{+}$.

Methyl 6-(2-((tert-Butyldimethylsilyloxy)methyl)-1-methyl$1 \mathrm{H}$-indol-5-yl)-1-(2,4-dimethoxybenzyl)-5-ethyl-4-hydroxy-2oxo-1,2-dihydropyridine-3-carboxylate (13c). To a stirred solution of $12 \mathrm{c}(4.14 \mathrm{~g}, 12.0 \mathrm{mmol})$ in $\mathrm{CH}_{2} \mathrm{Cl}_{2}(12 \mathrm{~mL})$ was added (2,4-dimethoxybenzylamine $(1.98 \mathrm{~mL}, 13.2 \mathrm{mmol})$ and $\mathrm{Et}_{3} \mathrm{~N}(4.5 \mathrm{~mL}$, $32.4 \mathrm{mmol})$ sequentially at $0{ }^{\circ} \mathrm{C}$. Then $\mathrm{TiCl}_{4}(7.8 \mathrm{~mL}, 1.0 \mathrm{M}$ in 
$\mathrm{CH}_{2} \mathrm{Cl}_{2}, 7.8 \mathrm{mmol}, 0.65$ equiv) was added to the reaction mixture via syringe pump over $30 \mathrm{~min}$. The reaction was warmed to room temperature and stirred overnight. The mixture was quenched by satd. $\mathrm{NaHCO}_{3}$ solution and extracted with $\mathrm{CH}_{2} \mathrm{Cl}_{2}(30 \mathrm{~mL} \times 5)$. The combined organic layers were dried over $\mathrm{Na}_{2} \mathrm{SO}_{4}$ and then concentrated under reduced pressure to give the crude product $(5.94 \mathrm{~g})$, which was carried into the next step without further purification. The crude imine $(5.94 \mathrm{~g}$, ca. $12.0 \mathrm{mmol})$ was dissolved in $\mathrm{Ph}_{2} \mathrm{O}(20 \mathrm{~mL})$ and trimethylmethanetricarboxylate (3.88 g, 20.4 $\mathrm{mmol}$ ) was added. A distillation apparatus was attached to the flask containing the reaction mixture. The reaction was heated to $230^{\circ} \mathrm{C}$ for $10 \mathrm{~min}$. The heating was removed after the distillation of methanol ceased. The mixture was cooled to room temperature and then purified by flash column chromatography $\left(0-50 \%\right.$ EtOAc in $\left.\mathrm{CH}_{2} \mathrm{Cl}_{2}\right)$ to give $13 \mathrm{c}(4.17 \mathrm{~g}, 6.72 \mathrm{mmol})$ in $56 \%$ yield. LC-MS $\mathrm{m} / z=621.3$ $[\mathrm{M}+\mathrm{H}]^{+} ;{ }^{1} \mathrm{H}$ NMR $\left(500 \mathrm{MHz}, \mathrm{CDCl}_{3}\right) \delta 0.08-0.14(\mathrm{~m}, 6 \mathrm{H}), 0.85-$ $0.94(\mathrm{~m}, 12 \mathrm{H}), 2.13(\mathrm{~m}, 2 \mathrm{H}), 3.16(\mathrm{~s}, 3 \mathrm{H}), 3.76(\mathrm{~s}, 3 \mathrm{H}), 3.78-3.81$ (m, $3 \mathrm{H}), 3.99-4.03(\mathrm{~m}, 3 \mathrm{H}), 4.78-4.87(\mathrm{~m}, 4 \mathrm{H}), 6.13$ (d, $J=2.29$ $\mathrm{Hz}, 1 \mathrm{H}), 6.30(\mathrm{~s}, 1 \mathrm{H}), 6.39(\mathrm{dd}, J=8.39,2.40 \mathrm{~Hz}, 1 \mathrm{H}), 6.79(\mathrm{~d}, J=$ $7.49 \mathrm{~Hz}, 1 \mathrm{H}), 6.84(\mathrm{~d}, J=8.43 \mathrm{~Hz}, 1 \mathrm{H}), 7.06(\mathrm{~s}, 1 \mathrm{H}), 7.22(\mathrm{~d}, J=$ $8.51 \mathrm{~Hz}, 1 \mathrm{H})$.

Methyl 6-(2-(((tert-Butyldimethylsilyl)oxy)methyl)-1-methyl$1 H$-indol-5-yl)-1-(2,4-dimethoxybenzyl)-4-hydroxy-5-isopropyl-2-oxo-1,2-dihydropyridine-3-carboxylate (13d). Compound 13d was prepared according to the procedure used to prepare $13 \mathrm{c}$ in $38 \%$ yield. LC-MS $m / z=635.5[\mathrm{M}+\mathrm{H}]^{+}$; ${ }^{1} \mathrm{H}$ NMR $(500 \mathrm{MHz}$, $\left.\mathrm{CDCl}_{3}\right) \delta 0.00(\mathrm{~s}, 3 \mathrm{H}), 0.01(\mathrm{~s}, 3 \mathrm{H}), 0.80-0.82(\mathrm{~m}, 9 \mathrm{H}), 1.04(\mathrm{dd}, J$ $=8.91,7.09 \mathrm{~Hz}, 6 \mathrm{H}), 2.23-2.34(\mathrm{~m}, 1 \mathrm{H}), 3.01(\mathrm{~s}, 3 \mathrm{H}), 3.65(\mathrm{~s}, 3$ $\mathrm{H}), 3.68(\mathrm{~s}, 3 \mathrm{H}), 3.89(\mathrm{~s}, 3 \mathrm{H}), 4.71(\mathrm{~d}, J=3.00 \mathrm{~Hz}, 2 \mathrm{H}), 4.78-4.90$ $(\mathrm{m}, 2 \mathrm{H}), 6.01(\mathrm{~d}, J=2.36 \mathrm{~Hz}, 1 \mathrm{H}), 6.19(\mathrm{~s}, 1 \mathrm{H}), 6.28(\mathrm{dd}, J=8.39$, $2.40 \mathrm{~Hz}, 1 \mathrm{H}), 6.61-6.70(\mathrm{~m}, 1 \mathrm{H}), 6.73(\mathrm{~d}, J=8.35 \mathrm{~Hz}, 1 \mathrm{H}), 6.86-$ $6.92(\mathrm{~m}, 1 \mathrm{H}), 7.08-7.14(\mathrm{~m}, 1 \mathrm{H})$.

Methyl 6-(2-(((tert-Butyldimethylsilyl)oxy)methyl)-1-methyl$1 H$-indol-5-yl)-5-cyclopropyl-1-(2,4-dimethoxybenzyl)-4-hydroxy-2-oxo-1,2-dihydropyridine-3-carboxylate (13e). Compound $13 \mathrm{e}$ was prepared according to the procedure used to prepare $13 \mathrm{c}$ in $37 \%$ yield. LC-MS $m / z=633.3[\mathrm{M}+\mathrm{H}]^{+}$; ${ }^{1} \mathrm{H}$ NMR (500 $\left.\mathrm{MHz} \mathrm{CDCl}_{3}\right) \delta 0.00(\mathrm{~d}, J=1.30 \mathrm{~Hz}, 6 \mathrm{H}$ ), 0.28 (ddd, $J=7.25,5.15$, $3.85 \mathrm{~Hz}, 4 \mathrm{H}), 0.81-0.82(\mathrm{~m}, 9 \mathrm{H}), 1.16(\mathrm{~s}, 1 \mathrm{H}), 3.14(\mathrm{~s}, 3 \mathrm{H}), 3.67$ $(\mathrm{s}, 3 \mathrm{H}), 3.70(\mathrm{~s}, 3 \mathrm{H}), 3.90(\mathrm{~s}, 3 \mathrm{H}), 4.73(\mathrm{~d}, J=2.52 \mathrm{~Hz}, 2 \mathrm{H}), 4.78-$ $4.85(\mathrm{~m}, 2 \mathrm{H}), 6.08(\mathrm{~d}, J=2.44 \mathrm{~Hz}, 1 \mathrm{H}), 6.21(\mathrm{~s}, 1 \mathrm{H}), 6.29(\mathrm{dd}, J=$ $8.47,2.37 \mathrm{~Hz}, 2 \mathrm{H}), 6.72(\mathrm{~d}, J=8.39 \mathrm{~Hz}, 1 \mathrm{H}), 7.03(\mathrm{~s}, 1 \mathrm{H}), 7.11(\mathrm{~d}, J$ $=8.47 \mathrm{~Hz}, 1 \mathrm{H})$.

Methyl 1-(2,4-Dimethoxybenzyl)-4-hydroxy-6-(2-(hydroxymethyl)-1-methyl-1 $H$-indol-5-yl)-2-oxo-1,2-dihydropyridine-3carboxylate (14a). Compound 14a was prepared from 13a according to the procedure used to prepare $14 \mathrm{c}$ in $70 \%$ yield. $\mathrm{LC}-\mathrm{MS} \mathrm{m} / \mathrm{z}=$ $479.1\left[\mathrm{M}+\mathrm{H}^{+}{ }^{+} ;{ }^{1} \mathrm{H}\right.$ NMR $\left(500 \mathrm{MHz}, \mathrm{CDCl}_{3}\right) \delta 3.33(\mathrm{~s}, 3 \mathrm{H}), 3.66(\mathrm{~s}$, $3 \mathrm{H}), 3.71(\mathrm{~s}, 3 \mathrm{H}), 3.87(\mathrm{~s}, 3 \mathrm{H}), 4.71(\mathrm{~d}, J=5.83 \mathrm{~Hz}, 2 \mathrm{H}), 4.90(\mathrm{~s}$, $2 \mathrm{H}), 5.90(\mathrm{~s}, 1 \mathrm{H}), 6.16(\mathrm{~d}, J=2.44 \mathrm{~Hz}, 1 \mathrm{H}), 6.28-6.32(\mathrm{~m}, 2 \mathrm{H}), 6.75$ $(\mathrm{d}, J=8.43 \mathrm{~Hz}, 1 \mathrm{H}), 6.91(\mathrm{dd}, J=8.51,1.73 \mathrm{~Hz}, 1 \mathrm{H}), 7.13(\mathrm{~d}, J=8.51$ $\mathrm{Hz}, 1 \mathrm{H}), 7.30$ (d, $J=1.18 \mathrm{~Hz}, 1 \mathrm{H}), 13.17$ (s, $1 \mathrm{H})$.

Methyl 1-(2,4-Dimethoxybenzyl)-4-hydroxy-6-(2-(hydroxymethyl)-1-methyl-1H-indol-5-yl)-5-methyl-2-oxo-1,2-dihydropyridine-3-carboxylate (14b). Compound $14 \mathrm{~b}$ was prepared according to the procedure used to prepare $14 \mathrm{c}$ in $52 \%$ yield. LCMS $m / z=493.3[\mathrm{M}+\mathrm{H}]^{+}$.

Methyl 1-(2,4-Dimethoxybenzyl)-5-ethyl-4-hydroxy-6-(2(hydroxymethyl)-1-methyl-1 $\mathrm{H}$-indol-5-yl)-2-oxo-1,2-dihydropyridine-3-carboxylate (14c). To a stirred solution of $13 \mathrm{c}(4.17 \mathrm{~g}$, $6.72 \mathrm{mmol})$ in THF $(10 \mathrm{~mL})$ was added TBAF $(8.1 \mathrm{~mL}, 8.1 \mathrm{mmol})$ at $0{ }^{\circ} \mathrm{C}$. The mixture was warmed to room temperature and stirred for 30 min. Additional TBAF $(5.4 \mathrm{~mL}, 5.4 \mathrm{mmol})$ was added to complete the reaction. The volatiles were removed under reduced pressure, and the crude product was purified by flash column chromatography $(0-50 \%$ EtOAc in $\left.\mathrm{CH}_{2} \mathrm{Cl}_{2}\right)$ to give $14 \mathrm{c}(3.13 \mathrm{~g}, 6.18 \mathrm{mmol})$ in $92 \%$ yield. $\mathrm{LC}-$ MS $m / z=507.2[\mathrm{M}+\mathrm{H}]^{+} ;{ }^{1} \mathrm{H}$ NMR $\left(500 \mathrm{MHz}, \mathrm{CDCl}_{3}\right) \delta 0.86-0.95$ $(\mathrm{m}, 3 \mathrm{H}), 2.07-2.21(\mathrm{~m}, 2 \mathrm{H}), 3.21(\mathrm{~s}, 3 \mathrm{H}), 3.74-3.78(\mathrm{~m}, 3 \mathrm{H})$, $3.82-3.86(\mathrm{~m}, 3 \mathrm{H}), 3.99-4.03(\mathrm{~m}, 3 \mathrm{H}), 4.83(\mathrm{~s}, 2 \mathrm{H}), 4.88-4.98$ $(\mathrm{m}, 2 \mathrm{H}), 6.15(\mathrm{~d}, J=2.36 \mathrm{~Hz}, 1 \mathrm{H}), 6.36-6.42(\mathrm{~m}, 2 \mathrm{H}), 6.78-6.88$ $(\mathrm{m}, 2 \mathrm{H}), 7.12(\mathrm{~s}, 1 \mathrm{H}), 7.25(\mathrm{~m}, 1 \mathrm{H})$.
Methyl 1-(2,4-Dimethoxybenzyl)-4-hydroxy-6-(2-(hydroxymethyl)-1-methyl-1H-indol-5-yl)-5-isopropyl-2-oxo-1,2-dihydropyridine-3-carboxylate (14d). Compound 14d was prepared according to the procedure used to prepare $14 \mathrm{c}$ in $71 \%$ yield. LC-MS $m / z=521.4[\mathrm{M}+\mathrm{H}]^{+} ;{ }^{1} \mathrm{H}$ NMR $\left(500 \mathrm{MHz}, \mathrm{CDCl}_{3}\right) \delta 1.02-1.08(\mathrm{~m}$, $6 \mathrm{H}), 2.23-2.32(\mathrm{~m}, 1 \mathrm{H}), 3.05(\mathrm{~s}, 3 \mathrm{H}), 3.66(\mathrm{~s}, 3 \mathrm{H}), 3.72(\mathrm{~s}, 3 \mathrm{H})$, $3.90(\mathrm{~s}, 3 \mathrm{H}), 4.66-4.83(\mathrm{~m}, 4 \mathrm{H}), 6.04(\mathrm{~d}, J=2.36 \mathrm{~Hz}, 1 \mathrm{H}), 6.26(\mathrm{~s}$, $1 \mathrm{H}), 6.29$ (dd, $J=8.43,2.36 \mathrm{~Hz}, 1 \mathrm{H}), 6.63-6.69(\mathrm{~m}, 1 \mathrm{H}), 6.72(\mathrm{~d}, J$ $=8.35 \mathrm{~Hz}, 1 \mathrm{H}), 6.94(\mathrm{~s}, 1 \mathrm{H}), 7.12(\mathrm{~d}, J=8.43 \mathrm{~Hz}, 1 \mathrm{H})$.

Methyl 5-Cyclopropyl-1-(2,4-dimethoxybenzyl)-4-hydroxy6-(2-(hydroxymethyl)-1-methyl-1H-indol-5-yl)-2-oxo-1,2-dihydropyridine-3-carboxylate (14e). Compound 14e was prepared according to the procedure used to prepare $14 \mathrm{c}$ in $74 \%$ yield. LC-MS $m / z=519.3[\mathrm{M}+\mathrm{H}]^{+}$.

1-(2,4-Dimethoxybenzyl)-4-hydroxy-6-(2-(hydroxymethyl)1-methyl-1H-indol-5-yl)-2-oxo-1,2-dihydropyridine-3-carboxylic Acid (15a). Compound 15a was prepared according to the procedure used to prepare $15 \mathrm{c}$ in $87 \%$ yield. LC-MS $m / z=465.2$ [M $+\mathrm{H}]^{+}$

1-(2,4-Dimethoxybenzyl)-4-hydroxy-6-(2-(hydroxymethyl)1-methyl-1H-indol-5-yl)-5-methyl-2-oxo-1,2-dihydropyridine3-carboxylic Acid (15b). Compound $15 \mathrm{~b}$ was prepared according to the procedure used to prepare $15 \mathrm{c}$ in $99 \%$ yield. LC-MS $m / z=479.2$ $[\mathrm{M}+\mathrm{H}]^{+}$.

1-(2,4-Dimethoxybenzyl)-5-ethyl-4-hydroxy-6-(2-(hydroxymethyl)-1-methyl-1H-indol-5-yl)-2-oxo-1,2-dihydropyridine-3carboxylic Acid (15c). To a suspension of $14 \mathrm{c}(3.13 \mathrm{~g}, 6.18 \mathrm{mmol})$ in EtOAc $(15 \mathrm{~mL})$ was added LiI $(2.48 \mathrm{~g}, 18.5 \mathrm{mmol})$ at room temperature. The mixture was heated to $65^{\circ} \mathrm{C}$ and then stirred for $1 \mathrm{~h}$. The reaction mixture was diluted with EtOAc $(30 \mathrm{~mL})$ and then quenched by satd. $\mathrm{Na}_{2} \mathrm{~S}_{2} \mathrm{O}_{3}(30 \mathrm{~mL})$. The organic phase was separated and the aqueous layer was extracted with EtOAc $(30 \mathrm{~mL} \times 4)$. The combined organic layers were dried over $\mathrm{Na}_{2} \mathrm{SO}_{4}$ and then concentrated to give $15 \mathrm{c}(2.89 \mathrm{~g}, 5.87 \mathrm{mmol})$ in $95 \%$ yield, which was carried on to the next step without further purification. LC-MS $m / z=493.2[\mathrm{M}+\mathrm{H}]^{+} ;{ }^{1} \mathrm{H}$ NMR $\left(500 \mathrm{MHz}, \mathrm{CDCl}_{3}\right) \delta 0.88-0.99(\mathrm{~m}$, $3 \mathrm{H}), 2.11-2.27(\mathrm{~m}, 2 \mathrm{H}), 3.29(\mathrm{~s}, 3 \mathrm{H}), 3.78(\mathrm{~s}, 3 \mathrm{H}), 3.85(\mathrm{~s}, 3 \mathrm{H})$, $4.81-4.87(\mathrm{~m}, 2 \mathrm{H}), 4.90(\mathrm{~d}, J=15.76 \mathrm{~Hz}, 1 \mathrm{H}), 4.99(\mathrm{~d}, J=15.84 \mathrm{~Hz}$, $1 \mathrm{H}), 6.21(\mathrm{~d}, J=2.36 \mathrm{~Hz}, 1 \mathrm{H}), 6.35-6.46(\mathrm{~m}, 2 \mathrm{H}), 6.69(\mathrm{~d}, J=8.43$ $\mathrm{Hz}, 1 \mathrm{H}), 6.85(\mathrm{dd}, J=8.43,1.66 \mathrm{~Hz}, 1 \mathrm{H}), 7.16(\mathrm{~d}, J=1.26 \mathrm{~Hz}, 1 \mathrm{H})$, $7.29-7.33(\mathrm{~m}, 1 \mathrm{H}), 13.97(\mathrm{~s}, 1 \mathrm{H}), 15.96(\mathrm{~s}, 1 \mathrm{H})$

1-(2,4-Dimethoxybenzyl)-4-hydroxy-6-(2-(hydroxymethyl)1-methyl-1H-indol-5-yl)-5-isopropyl-2-oxo-1,2-dihydropyridine-3-carboxylic Acid (15d). Compound 15d was prepared according to the procedure used to prepare $15 \mathrm{c}$ in $74 \%$ yield. LCMS $m / z=507.2[\mathrm{M}+\mathrm{H}]^{+}$.

5-Cyclopropyl-1-(2,4-dimethoxybenzyl)-4-hydroxy-6-(2-(hydroxymethyl)-1-methyl-1H-indol-5-yl)-2-oxo-1,2-dihydropyridine-3-carboxylic Acid (15e). Compound 15e was prepared according to the procedure used to prepare $15 \mathrm{c}$ in $85 \%$ yield. LCMS $m / z=505.3[\mathrm{M}+\mathrm{H}]^{+}$.

1-(2,5-Dimethoxybenzyl)-6-(2-formyl-1-methyl- $1 \mathrm{H}$-indol-5yl)-4-hydroxy-2-oxo-1,2-dihydropyridine-3-carboxylic Acid (16a). Compound 16a was prepared according to the procedure used to prepare $16 \mathrm{c}$ in $76 \%$ yield. $\mathrm{LC}-\mathrm{MS} m / z=461.1[\mathrm{M}-\mathrm{H}]^{-} ;{ }^{1} \mathrm{H}$ $\operatorname{NMR}\left(500 \mathrm{MHz}, \mathrm{CDCl}_{3}\right) \delta 3.42(\mathrm{~s}, 3 \mathrm{H}), 3.81(\mathrm{~s}, 3 \mathrm{H}), 4.15(\mathrm{~s}, 3 \mathrm{H})$ 5.12 (br. s, $2 \mathrm{H}$ ), 5.33 (br. s, $1 \mathrm{H}), 6.22-6.35$ (m, $2 \mathrm{H}), 6.44$ (br. s, 1 H), 6.79 (br. s, $1 \mathrm{H}), 7.24$ (br. s, $2 \mathrm{H}), 7.42$ (br. s, $1 \mathrm{H}), 7.59$ (s, $1 \mathrm{H})$, 9.96 (br. s, $1 \mathrm{H}$ ), 13.55 (br. s, $1 \mathrm{H}), 15.37$ (br. s, $1 \mathrm{H}$ ).

1-(2,4-Dimethoxybenzyl)-6-(2-formyl-1-methyl-1 $\mathrm{H}$-indol-5yl)-4-hydroxy-5-methyl-2-oxo-1,2-dihydropyridine-3-carboxylic Acid (16b). Compound 16b was prepared according to the procedure used to prepare $16 \mathrm{c}$ in $64 \%$ yield. LC-MS $m / z=477.3$ [M $+\mathrm{H}]^{+}$

1-(2,4-Dimethoxybenzyl)-5-ethyl-6-(2-formyl-1-methyl-1Hindol-5-yl)-4-hydroxy-2-oxo-1,2-dihydropyridine-3-carboxylic Acid (16c). To a suspension of $15 \mathrm{c}(2.89 \mathrm{~g}, 5.87 \mathrm{mmol})$ in $\mathrm{CH}_{2} \mathrm{Cl}_{2}$ ( $30 \mathrm{~mL})$ was added $\mathrm{MnO}_{2}(5.1 \mathrm{~g}, 58.7 \mathrm{mmol}, 10$ equiv) at room temperature. After $1 \mathrm{~h}$, an additional portion of $\mathrm{MnO}_{2}(5.1 \mathrm{~g}, 58.7$ mmol, 10 equiv) was added. Upon completion, the reaction mixture was filtered through Celite to remove the solids. The filtrate was concentrated to give crude $16 \mathrm{c}(2.45 \mathrm{~g}, 4.99 \mathrm{mmol})$, which was used in 
the next step without further purification. LC-MS $m / z=491.3[\mathrm{M}+$ $\mathrm{H}]^{+}$; ${ }^{1} \mathrm{H}$ NMR $\left(500 \mathrm{MHz}, \mathrm{CDCl}_{3}\right) \delta 0.93(\mathrm{t}, J=7.41 \mathrm{~Hz}, 3 \mathrm{H}), 2.11-$ $2.26(\mathrm{~m}, 2 \mathrm{H}), 3.19(\mathrm{~s}, 3 \mathrm{H}), 3.79(\mathrm{~s}, 3 \mathrm{H}), 4.14(\mathrm{~s}, 3 \mathrm{H}), 4.88(\mathrm{~d}, J=$ $15.76 \mathrm{~Hz}, 1 \mathrm{H}), 5.04(\mathrm{~d}, J=15.84 \mathrm{~Hz}, 1 \mathrm{H}), 6.18(\mathrm{~d}, J=2.36 \mathrm{~Hz}, 1 \mathrm{H})$, $6.42(\mathrm{dd}, J=8.43,2.36 \mathrm{~Hz}, 1 \mathrm{H}), 6.73(\mathrm{~d}, J=8.35 \mathrm{~Hz}, 1 \mathrm{H}), 7.03(\mathrm{dd}$, $J=8.67,1.58 \mathrm{~Hz}, 1 \mathrm{H}), 7.21(\mathrm{~s}, 1 \mathrm{H}), 7.40(\mathrm{~d}, J=8.67 \mathrm{~Hz}, 1 \mathrm{H}), 9.94$ $(\mathrm{s}, 1 \mathrm{H}), 14.03(\mathrm{~s}, 1 \mathrm{H}), 15.88(\mathrm{~s}, 1 \mathrm{H})$.

1-(2,4-Dimethoxybenzyl)-6-(2-formyl-1-methyl-1H-indol-5yl)-4-hydroxy-5-isopropyl-2-oxo-1,2-dihydropyridine-3-carboxylic Acid (16d). Compound $16 \mathrm{~d}$ was prepared according to the procedure used to prepare $16 \mathrm{c}$ in $81 \%$ yield. LC-MS $m / z=505.4[\mathrm{M}$ $+\mathrm{H}]^{+}$.

5-Cyclopropyl-1-(2,4-dimethoxybenzyl)-6-(2-formyl-1-methyl-1H-indol-5-yl)-4-hydroxy-2-oxo-1,2-dihydropyridine-3-carboxylic Acid (16e). Compound 16e was prepared according to the procedure used to prepare $16 \mathrm{c}$ in $72 \%$ yield. LC-MS $m / z=503.2[\mathrm{M}$ $+\mathrm{H}]^{+}$.

6-Chloro-2-(hydroxymethyl)-1H-indole-5-carbonitrile (17). To a solution of 4-amino-2-chloro-5-iodobenzonitrile ${ }^{18}$ (51.73 g, 186 $\mathrm{mmol})$ in $\mathrm{CH}_{3} \mathrm{CN}(270 \mathrm{~mL})$ was added propargyl alcohol $(13.3 \mathrm{~mL}$, $223 \mathrm{mmol})$ and $\mathrm{NEt}_{3}(52 \mathrm{~mL}, 373 \mathrm{mmol})$. The mixture was degassed with argon before $\mathrm{Pd}\left(\mathrm{PPh}_{3}\right)_{2} \mathrm{Cl}_{2}(1.30 \mathrm{~g}, 1.85 \mathrm{mmol})$ and $\mathrm{CuI}(0.70 \mathrm{~g}$, $3.67 \mathrm{mmol}$ ) were added. The reaction was heated at $70^{\circ} \mathrm{C}$ for $2 \mathrm{~h}$ until starting material was completely consumed. After cooling to room temperature, the solvent was concentrated. Water $(300 \mathrm{~mL})$ was added, and the precipitate was filtered, washed with $\mathrm{H}_{2} \mathrm{O}(200 \mathrm{~mL} \times$ 2 ), and dried with a $\mathrm{N}_{2}$ flow. Crude alkyne intermediate was obtained as $\tan$ solid $(40.0 \mathrm{~g})$ and was used directly in the next step. To a solution of the intermediate $(36.70 \mathrm{~g}, 178 \mathrm{mmol})$ in DMF $(450 \mathrm{~mL})$ was added $t$-BuOK $(44.0 \mathrm{~g}, 392 \mathrm{mmol})$, and the mixture was heated at $70{ }^{\circ} \mathrm{C}$ for $2 \mathrm{~h}$ under an argon atmosphere. Upon cooling to room temperature, the mixture was carefully poured into a mixture of ice $(\sim 800 \mathrm{~mL})$ and conc. $\mathrm{HCl}(50 \mathrm{~mL})$. The precipitate was filtered and washed with $\mathrm{H}_{2} \mathrm{O}(300 \mathrm{~mL} \times 2)$ and dried affording 17 as a brownish solid (28.50 g, 77\% over 2 steps). LC-MS $m / z=207.1,209.1[\mathrm{M}+$ $\mathrm{H}]^{+} ;{ }^{1} \mathrm{H}$ NMR $(500 \mathrm{MHz}$, DMSO-d 6 ) $\delta 4.63(\mathrm{~d}, J=5.7 \mathrm{~Hz}, 2 \mathrm{H}), 5.47$ $(\mathrm{t}, J=5.7 \mathrm{~Hz}, 1 \mathrm{H}), 6.44(\mathrm{~s}, 1 \mathrm{H}), 7.58(\mathrm{~s}, 1 \mathrm{H}), 8.12(\mathrm{~s}, 1 \mathrm{H}), 11.79$ (br. s, $1 \mathrm{H})$

2-((tert-Butyldimethylsilyloxy)methyl)-6-chloro- $1 \mathrm{H}$-indole-5carbonitrile (18). A solution of $17(32.66 \mathrm{~g}, 158 \mathrm{mmol})$ and imidazole $(14.0 \mathrm{~g}, 205 \mathrm{mmol})$ in DMF $(450 \mathrm{~mL})$ was stirred at room temperature for $5 \mathrm{~min}$ before TBSCl $(29.0 \mathrm{~g} 192 \mathrm{mmol})$ was added in one portion. The reaction was stirred at room temperature for $1.5 \mathrm{~h}$ and then poured into ice $\mathrm{H}_{2} \mathrm{O}$ (total final volume $\approx 1700 \mathrm{~mL}$ ). A dark brown oil was formed, which solidified upon the addition of pentane $(\sim 100 \mathrm{~mL})$. The resulting solid was filtered, washed with $\mathrm{H}_{2} \mathrm{O}(300$ $\mathrm{mL} \times 2)$, and dried overnight. The solid was washed with pentane $(300 \mathrm{~mL} \times 2)$ and then suspended in $800 \mathrm{~mL}$ of $\mathrm{CH}_{2} \mathrm{Cl}_{2}$. The resulting mixture was stirred vigorously at room temperature for $1 \mathrm{~h}$ and then filtered through Celite. The mother liquor was concentrated to yield 18 as a brownish solid ( $37.42 \mathrm{~g}, 74 \%)$, which was used in the next step without further purification. LC-MS $m / z=321.2,323.2[\mathrm{M}$ $+\mathrm{H}]^{+}$; ${ }^{1} \mathrm{H}$ NMR $\left(500 \mathrm{MHz}, \mathrm{CDCl}_{3}\right) \delta 0.13(\mathrm{~s}, 6 \mathrm{H}), 0.94(\mathrm{~s}, 9 \mathrm{H})$, 4.88 (s, $2 \mathrm{H}), 6.36$ (s, $1 \mathrm{H}), 7.49$ (s, $1 \mathrm{H}), 7.89$ (s, $1 \mathrm{H}), 8.63$ (br. s, 1 $\mathrm{H})$.

2-((tert-Butyldimethylsilyloxy)methyl)-6-chloro-1-methyl$1 \mathrm{H}$-indole-5-carbonitrile (19). To a solution of crude $18(37.50 \mathrm{~g}$, $117 \mathrm{mmol})$ in DMF $(400 \mathrm{~mL})$ at $0{ }^{\circ} \mathrm{C}$ was added $\mathrm{NaH}(60 \%, 6.7 \mathrm{~g}$, $168 \mathrm{mmol}$ ) in portions. Upon completion of the addition, the mixture was warmed to room temperature with stirring for $10 \mathrm{~min}$. The reaction mixture was cooled to $0{ }^{\circ} \mathrm{C}$, and $\mathrm{MeI}(10.5 \mathrm{~mL}, 169 \mathrm{mmol})$ was added. The reaction mixture was warmed to room temperature and stirred for $1.5 \mathrm{~h}$ and then poured into ice $\mathrm{H}_{2} \mathrm{O}$ and $100 \mathrm{~mL}$ of $1 \mathrm{M}$ $\mathrm{HCl}$ (final volume $\sim 1600 \mathrm{~mL}$ ). The precipitate was filtered, washed with $\mathrm{H}_{2} \mathrm{O}(200 \mathrm{~mL} \times 3)$, and dried overnight. The solid was then washed with pentane $(200 \mathrm{~mL} \times 2)$. The crude product, obtained as a brownish solid $(39.0 \mathrm{~g})$, was purified by column chromatography $\left(\mathrm{CH}_{2} \mathrm{Cl}_{2} /\right.$ hexanes, $\left.50-100 \%\right)$ to yield 19 as a pale orange solid $(30.0$ g, $76 \%$ yield). $\mathrm{LC}-\mathrm{MS} m / z=335.2,337.2[\mathrm{M}+\mathrm{H}]^{+} ;{ }^{1} \mathrm{H}$ NMR (500
$\left.\mathrm{MHz}, \mathrm{CDCl}_{3}\right) \delta 0.08(\mathrm{~s}, 6 \mathrm{H}), 0.90(\mathrm{~s}, 9 \mathrm{H}), 3.79(\mathrm{~s}, 3 \mathrm{H}), 4.82(\mathrm{~s}, 2$ $\mathrm{H}), 6.44(\mathrm{~s}, 1 \mathrm{H}), 7.41(\mathrm{~s}, 1 \mathrm{H}), 7.90(\mathrm{~s}, 1 \mathrm{H})$.

2-((tert-Butyldimethylsilyloxy)methyl)-6-chloro-1-methyl$1 \mathrm{H}$-indole-5-carbaldehyde (20). To a solution of 19 (4.15 g, 12.4 $\mathrm{mmol})$ in $\mathrm{CH}_{2} \mathrm{Cl}_{2}(50 \mathrm{~mL})$ at $-78{ }^{\circ} \mathrm{C}$ was added DIBAL-H $(1 \mathrm{M}$ in $\mathrm{CH}_{2} \mathrm{Cl}_{2}, 15.0 \mathrm{~mL}, 15.0 \mathrm{mmol}$ ) dropwise over $10 \mathrm{~min}$. The reaction was stirred at this temperature for $10 \mathrm{~min}$ and slowly warmed to $-15{ }^{\circ} \mathrm{C}$ over $\sim 2 \mathrm{~h}$. The reaction mixture was then cooled to $-40{ }^{\circ} \mathrm{C}$ and quenched upon the addition of Rochelle salt solution (aq. satd., 20 $\mathrm{mL}$ ). The resulting emulsion was warmed to room temperature and vigorously stirred for $\sim 1 \mathrm{~h}$. The organic phase was separated, and the aqueous layer was extracted with $\mathrm{CH}_{2} \mathrm{Cl}_{2}(50 \mathrm{~mL})$. The combined organic layers were washed sequentially with $1 \mathrm{M} \mathrm{HCl}(50 \mathrm{~mL})$, $\mathrm{NaHCO}_{3}$ (aq. satd., $50 \mathrm{~mL}$ ), and brine $(50 \mathrm{~mL})$ and then dried over $\mathrm{Na}_{2} \mathrm{SO}_{4}$. After solvent removal in vacuo, the crude product was purified by column chromatography (EtOAc/hexanes, 5-15\%) affording 20 as an off-white solid (3.80 g, 91\%). LC-MS $\mathrm{m} / \mathrm{z}=$ 338.2, $340.3[\mathrm{M}+\mathrm{H}]^{+} ;{ }^{1} \mathrm{H} \mathrm{NMR}\left(500 \mathrm{MHz}, \mathrm{CDCl}_{3}\right) \delta 0.08(\mathrm{~s}, 6 \mathrm{H})$, $0.90(\mathrm{~s}, 9 \mathrm{H}), 3.79(\mathrm{~s}, 3 \mathrm{H}), 4.82(\mathrm{~s}, 2 \mathrm{H}), 6.49(\mathrm{~s}, 1 \mathrm{H}), 7.33(\mathrm{~s}, 1 \mathrm{H})$, $8.21(\mathrm{~s}, 1 \mathrm{H}), 10.50(\mathrm{~s}, 1 \mathrm{H})$.

2-((tert-Butyldimethylsilyloxy)methyl)-1-methyl-6-vinyl-1 $\mathrm{H}$ indole-5-carbaldehyde (21). Compound 20 (3.80 g, $11.24 \mathrm{mmol})$, potassium vinyltrifluoroborate $(2.30 \mathrm{~g}, 17.17 \mathrm{mmol}), \mathrm{Pd}(\mathrm{OAc})_{2}(76$ $\mathrm{mg}, 0.34 \mathrm{mmol}, 0.03$ equiv), S-Phos ligand $(280 \mathrm{mg}, 0.68 \mathrm{mmol}, 0.06$ equiv), and $\mathrm{K}_{2} \mathrm{CO}_{3}(4.70 \mathrm{~g}, 34.0 \mathrm{mmol})$ were mixed together in a 100 $\mathrm{mL}$ round-bottom flask. The flask was purged and backfilled with argon before dioxane $(45 \mathrm{~mL})$ and $\mathrm{H}_{2} \mathrm{O}(7.5 \mathrm{~mL})$ were added. The reaction was heated at $85-90{ }^{\circ} \mathrm{C}$ for $5 \mathrm{~h}$ and then cooled to room temperature. Water $(30 \mathrm{~mL})$ was added, and the product was extracted with $\mathrm{CH}_{2} \mathrm{Cl}_{2}(80 \mathrm{~mL} \times 3)$. The combined organic phases were washed with brine $(80 \mathrm{~mL})$ and dried over $\mathrm{Na}_{2} \mathrm{SO}_{4}$. After removal of the solvents, purification by column chromatography (EtOAc/hexanes, $0-$ $10 \%$ gradient) afforded 21 as a white solid (3.32 g, 89\%). LC-MS $\mathrm{m} / \mathrm{z}$ $=330.3[\mathrm{M}+\mathrm{H}]^{+} ;{ }^{1} \mathrm{H}$ NMR $\left(500 \mathrm{MHz}, \mathrm{CDCl}_{3}\right) \delta 0.09(\mathrm{~s}, 6 \mathrm{H}), 0.91$ $(\mathrm{s}, 9 \mathrm{H}), 3.84(\mathrm{~s}, 3 \mathrm{H}), 4.85(\mathrm{~s}, 2 \mathrm{H}), 5.42(\mathrm{dd}, J=10.7,1.7 \mathrm{~Hz}, 1 \mathrm{H})$, 5.69 (dd, $J=17.2,1.7 \mathrm{~Hz}, 1 \mathrm{H}), 6.51(\mathrm{~s}, 1 \mathrm{H}), 7.43(\mathrm{~s}, 1 \mathrm{H}), 7.75$ (dd, $J=17.3,10.7 \mathrm{~Hz}, 1 \mathrm{H}), 8.07(\mathrm{~s}, 1 \mathrm{H}), 10.24(\mathrm{~s}, 1 \mathrm{H})$.

1-(2-((tert-Butyldimethylsilyloxy)methyl)-1-methyl-6-vinyl$1 H$-indol-5-yl)pent-4-en-1-ol (22c). To a solution of 21 (8.23 g, $24.98 \mathrm{mmol})$ in THF $(50 \mathrm{~mL})$ at $-78{ }^{\circ} \mathrm{C}$ was added $3-$ butenylmagnesium bromide $(0.5 \mathrm{M}$ in THF, $60.0 \mathrm{~mL}, 30.0 \mathrm{mmol})$ dropwise over $\sim 10 \mathrm{~min}$. The reaction was stirred at this temperature for $10 \mathrm{~min}$ and slowly allowed to warm to $-10{ }^{\circ} \mathrm{C}$. The reaction was quenched by the addition of $\mathrm{NH}_{4} \mathrm{Cl}$ (aq. satd., $80 \mathrm{~mL}$ ) and was extracted with EtOAc $(150 \mathrm{~mL} \times 4)$. The combined organic layers were washed with brine $(100 \mathrm{~mL})$ and dried over $\mathrm{Na}_{2} \mathrm{SO}_{4}$. Upon removal of the solvent, the product was obtained as a pale-yellow oil (9.60 g, quant), which solidified under high vacuum. Compound $22 \mathrm{c}$ (>95\% purity) was used directly in the next step without purification. LC-MS $m / z=386.3[\mathrm{M}+\mathrm{H}]^{+} ;{ }^{1} \mathrm{H}$ NMR $\left(500 \mathrm{MHz}, \mathrm{CDCl}_{3}\right) \delta 0.06$ $(\mathrm{s}, 3 \mathrm{H}), 0.07$ (s, $3 \mathrm{H}), 0.90(\mathrm{~s}, 9 \mathrm{H}), 1.86-1.99(\mathrm{~m}, 2 \mathrm{H}), 2.11-2.31$ $(\mathrm{m}, 2 \mathrm{H}), 3.80(\mathrm{~s}, 3 \mathrm{H}), 4.82(\mathrm{~s}, 2 \mathrm{H}), 4.99(\mathrm{~d}, J=10.4 \mathrm{~Hz}, 1 \mathrm{H}), 5.06$ (dd, $J=17.2,1.7 \mathrm{~Hz}, 1 \mathrm{H}), 5.11(\mathrm{dd}, J=7.3,5.7 \mathrm{~Hz}, 1 \mathrm{H}), 5.29$ (dd, $J$ $=10.4,1.7 \mathrm{~Hz}, 1 \mathrm{H}), 5.65(\mathrm{dd}, J=17.2,1.7 \mathrm{~Hz}, 1 \mathrm{H}), 5.83-5.93(\mathrm{~m}, 1$ $\mathrm{H}), 6.34(\mathrm{~s}, 1 \mathrm{H}), 7.23(\mathrm{dd}, J=17.2,10.9 \mathrm{~Hz}, 1 \mathrm{H}), 7.40(\mathrm{~s}, 1 \mathrm{H}), 7.66$ (s, $1 \mathrm{H})$.

2-((tert-Butyldimethylsilyloxy)methyl)-1-methyl-1,5,6,7tetrahydrocyclohepta[f]indol-5-ol (23c). Compound 22c (24.98 $\mathrm{mmol}$ ) was dissolved in toluene $(500 \mathrm{~mL}, 0.05 \mathrm{M})$ under an argon atmosphere. Grubbs second generation catalyst $(640 \mathrm{mg}, 0.75 \mathrm{mmol}$, 0.03 equiv) was added, and the mixture was heated at $60{ }^{\circ} \mathrm{C}$ for $3 \mathrm{~h}$ until starting material was completely consumed. Upon cooling to room temperature, toluene was removed under reduced pressure, and the residue was purified by column chromatography (EtOAc/hexanes, $0-20 \%$ gradient) to yield $23 \mathrm{c}$ as a yellow solid. LC-MS $m / z=358.3$ $[\mathrm{M}+\mathrm{H}]^{+} ;{ }^{1} \mathrm{H}$ NMR $\left(500 \mathrm{MHz}, \mathrm{CDCl}_{3}\right) \delta 0.06(\mathrm{~s}, 6 \mathrm{H}), 0.90(\mathrm{~s}, 9 \mathrm{H})$, 1.92 (br. s, $1 \mathrm{H}), 2.08-2.19(\mathrm{~m}, 1 \mathrm{H}), 2.23-2.34(\mathrm{~m}, 1 \mathrm{H}), 2.42-2.51$ $(\mathrm{m}, 1 \mathrm{H}), 2.56-2.71(\mathrm{~m}, 1 \mathrm{H}), 3.77(\mathrm{~s}, 3 \mathrm{H}), 4.82(\mathrm{~s}, 2 \mathrm{H}), 5.03(\mathrm{~d}, J=$ $8.2 \mathrm{~Hz}, 1 \mathrm{H}), 5.84-5.91(\mathrm{~m}, 1 \mathrm{H}), 6.34(\mathrm{~s}, 1 \mathrm{H}), 6.56(\mathrm{~d}, J=12.3 \mathrm{~Hz}$, $1 \mathrm{H}), 7.14(\mathrm{~s}, 1 \mathrm{H}), 7.57(\mathrm{~s}, 1 \mathrm{H})$. 
2-((tert-Butyldimethylsilyloxy)methyl)-1-methyl-6,7,8,9tetrahydrocyclohepta[f]indol-5(1H)-one (24c). A solution of $23 \mathrm{c}$ $(24.98 \mathrm{mmol})$ in EtOAc $(105 \mathrm{~mL})$ and $\mathrm{CH}_{2} \mathrm{Cl}_{2}(15 \mathrm{~mL})$ was hydrogenated over $\mathrm{Pd} / \mathrm{C}(10 \%, 880 \mathrm{mg})$ under a $\mathrm{H}_{2}$-filled balloon (1 $\mathrm{atm})$ for $\sim 3 \mathrm{~h}$. The catalyst was filtered and washed with EtOAc. The filtrate was concentrated, and the intermediate obtained as a brown solid was taken directly into the next step. To activated $4 \AA$ molecular sieves $(6.2 \mathrm{~g}, 250 \mathrm{mg} / \mathrm{mmol})$ was added a solution of the intermediate obtained above $(24.98 \mathrm{mmol})$ in $\mathrm{CH}_{2} \mathrm{Cl}_{2}(125 \mathrm{~mL})$. The mixture was cooled to $0{ }^{\circ} \mathrm{C}$ before NMO $(4.45 \mathrm{~g}, 37.99 \mathrm{mmol})$ and TPAP (445 $\mathrm{mg}, 1.26 \mathrm{mmol}, 0.05$ equiv) were added sequentially. The reaction was stirred at $0{ }^{\circ} \mathrm{C}$. Upon complete consumption of starting material $(\sim 1.5$ $\mathrm{h}$ ), the molecular sieves were filtered off and washed with $\mathrm{CH}_{2} \mathrm{Cl}_{2}$. The filtrate was concentrated, and the residue was purified by column chromatography (EtOAc/hexanes, $0-25 \%$ gradient) to provide $24 \mathrm{c}$ as an off-white solid (7.47 g, 84\% over 4 steps). LC-MS $m / z=358.3$ [M $+\mathrm{H}]^{+}$; ${ }^{1} \mathrm{H}$ NMR $\left(500 \mathrm{MHz}, \mathrm{CDCl}_{3}\right) \delta 0.06(\mathrm{~s}, 6 \mathrm{H}), 0.90(\mathrm{~s}, 9 \mathrm{H})$, $1.76-1.84(\mathrm{~m}, 2 \mathrm{H}), 1.88-1.95(\mathrm{~m}, 2 \mathrm{H}), 2.74-2.77(\mathrm{~m}, 2 \mathrm{H}), 3.05(\mathrm{t}$, $J=6.6 \mathrm{~Hz}, 2 \mathrm{H}), 3.79(\mathrm{~s}, 3 \mathrm{H}), 4.82(\mathrm{~s}, 2 \mathrm{H}), 6.43(\mathrm{~s}, 1 \mathrm{H}), 7.06(\mathrm{~s}, 1$ $\mathrm{H}), 8.04(\mathrm{~s}, 1 \mathrm{H})$.

Methyl 10-((tert-Butyldimethylsilyl)oxy)methyl)-1-(2,4-dimethoxybenzyl)-4-hydroxy-9-methyl-2-oxo-1,2,5,6,7,9hexahydropyrido $\left[3^{\prime}, 2^{\prime}: 6,7\right]$ cyclohepta[1,2-f]indole-3-carboxylate $(25 \mathrm{c})$. Following the two-step procedure used to prepare $13 \mathrm{c}$, compound 24c $(7.458 \mathrm{~g}, 20.86 \mathrm{mmol})$ gave, after chromatographic purification (0-80\% EtOAc/hexanes), $25 \mathrm{c}$ as a yellow foam (7.44 g, $56 \%)$. LC-MS $m / z=633.5\left[\mathrm{M}+\mathrm{H}^{+}{ }^{+}{ }^{1} \mathrm{H}\right.$ NMR $\left(500 \mathrm{MHz}, \mathrm{CDCl}_{3}\right)$ $\delta 0.08(\mathrm{~s}, 3 \mathrm{H}), 0.09(\mathrm{~s}, 3 \mathrm{H}), 0.90(\mathrm{~s}, 9 \mathrm{H}), 1.45-1.55(\mathrm{~m}, 1 \mathrm{H})$, $1.85-1.95(\mathrm{~m}, 1 \mathrm{H}), 1.96-2.05(\mathrm{~m}, 1 \mathrm{H}), 2.32-2.44(\mathrm{~m}, 1 \mathrm{H}), 2.58$ (dd, $J=13.4,6.1 \mathrm{~Hz}, 1 \mathrm{H}), 2.96(\mathrm{dd}, J=13.4,5.4 \mathrm{~Hz}, 1 \mathrm{H}), 3.33(\mathrm{~s}, 3$ $\mathrm{H}), 3.76(\mathrm{~s}, 3 \mathrm{H}), 3.78(\mathrm{~s}, 3 \mathrm{H}), 4.00(\mathrm{~s}, 3 \mathrm{H}), 4.80(\mathrm{~s}, 2 \mathrm{H}), 5.13-5.37$ $(\mathrm{m}, 2 \mathrm{H}), 6.22(\mathrm{~d}, J=2.2 \mathrm{~Hz}, 1 \mathrm{H}), 6.28(\mathrm{~s}, 1 \mathrm{H}), 6.34(\mathrm{dd}, J=8.4,2.2$ $\mathrm{Hz}, 1 \mathrm{H}), 6.81(\mathrm{~d}, J=8.4 \mathrm{~Hz}, 1 \mathrm{H}), 7.06(\mathrm{~s}, 1 \mathrm{H}), 7.32(\mathrm{~s}, 1 \mathrm{H}), 13.66$ (br. s, $1 \mathrm{H}$ ).

1-(2,4-Dimethoxybenzyl)-4-hydroxy-10-(hydroxymethyl)-9methyl-2-oxo-1, 2,5,6,7,9-hexahydropyrido $\left[3^{\prime}, 2^{\prime}: 6,7\right]-$ cyclohepta[1,2-f]indole-3-carboxylic Acid (26c). Following the procedure used to prepare $14 \mathrm{c}$, compound $25 \mathrm{c}(7.44 \mathrm{~g}, 11.76 \mathrm{mmol})$ gave the alcohol intermediate as a yellow solid $(5.94 \mathrm{~g}, 97 \%)$ after column chromatography (EtOAc/ $\mathrm{CH}_{2} \mathrm{Cl}_{2}, 0-100 \%$ ). LC-MS $\mathrm{m} / z=$ $519.3[\mathrm{M}+\mathrm{H}]^{+} ;{ }^{1} \mathrm{H}$ NMR $\left(500 \mathrm{MHz}, \mathrm{CDCl}_{3}\right) \delta 1.49(\mathrm{td}, J=13.6,6.9$ $\mathrm{Hz}, 1 \mathrm{H}), 1.84-1.95(\mathrm{~m}, 1 \mathrm{H}), 1.96-2.05(\mathrm{~m}, 1 \mathrm{H}), 2.38(\mathrm{td}, J=12.8$, $7.6 \mathrm{~Hz}, 1 \mathrm{H}), 2.59(\mathrm{dd}, J=13.2,6.3 \mathrm{~Hz}, 1 \mathrm{H}), 2.96(\mathrm{dd}, J=13.2,5.2$ $\mathrm{Hz}, 1 \mathrm{H}), 3.33(\mathrm{~s}, 3 \mathrm{H}), 3.75(\mathrm{~s}, 3 \mathrm{H}), 3.81(\mathrm{~s}, 3 \mathrm{H}), 4.00(\mathrm{~s}, 3 \mathrm{H}), 4.80$ $(\mathrm{s}, 2 \mathrm{H}), 5.11-5.30(\mathrm{~m}, 2 \mathrm{H}), 6.22(\mathrm{~d}, J=2.5 \mathrm{~Hz}, 1 \mathrm{H}), 6.32-6.38(\mathrm{~m}$, $2 \mathrm{H}), 6.79(\mathrm{~d}, J=8.5 \mathrm{~Hz}, 1 \mathrm{H}), 7.07(\mathrm{~s}, 1 \mathrm{H}), 7.35(\mathrm{~s}, 1 \mathrm{H}), 13.72$ (br. $\mathrm{s}, 1 \mathrm{H})$. Following the procedure used to prepare $15 \mathrm{c}$, the alcohol intermediate $(5.94 \mathrm{~g}, 11.45 \mathrm{mmol})$ was converted to $26 \mathrm{c}$ as a yellow solid (5.24 g, 91\%). LC-MS $m / z=505.2[\mathrm{M}+\mathrm{H}]^{+} ;{ }^{1} \mathrm{H}$ NMR (500 MHz, DMSO- $\left.d_{6}\right) \delta 1.45(\mathrm{td}, J=13.3,7.4 \mathrm{~Hz}, 1 \mathrm{H}), 1.85-1.98(\mathrm{~m}, 2$ $\mathrm{H}), 2.29-2.40(\mathrm{~m}, 1 \mathrm{H}), 2.60-2.70(\mathrm{~m}, 1 \mathrm{H}), 2.86(\mathrm{dd}, J=13.2,5.4$ $\mathrm{Hz}, 1 \mathrm{H}), 3.43(\mathrm{~s}, 3 \mathrm{H}), 3.69(\mathrm{~s}, 3 \mathrm{H}), 3.74(\mathrm{~s}, 3 \mathrm{H}), 4.62(\mathrm{~s}, 2 \mathrm{H})$, $5.13-5.33(\mathrm{~m}, 2 \mathrm{H}), 6.31(\mathrm{~s}, 1 \mathrm{H}), 6.36(\mathrm{dd}, J=8.4,2.2 \mathrm{~Hz}, 1 \mathrm{H}), 6.39$ $(\mathrm{d}, J=2.2 \mathrm{~Hz}, 1 \mathrm{H}), 6.59(\mathrm{~d}, J=8.4 \mathrm{~Hz}, 1 \mathrm{H}), 7.35(\mathrm{~s}, 1 \mathrm{H}), 7.52(\mathrm{~s}, 1$ $\mathrm{H}), 13.74(\mathrm{~s}, 1 \mathrm{H})$.

1-(2,4-Dimethoxybenzyl)-10-formyl-4-hydroxy-9-methyl-2oxo-1,2,5,6,7,9-hexahydropyrido[3',2':6,7]cyclohepta[1,2-f]indole-3-carboxylic Acid (27c). Following the procedure used to prepare $16 \mathrm{c}$, compound $26 \mathrm{c}(5.24 \mathrm{~g}, 10.39 \mathrm{mmol})$ was converted to $27 \mathrm{c}$ as a dark red foam $(4.30 \mathrm{~g}, 82 \%)$. LC-MS $m / z=501.1[\mathrm{M}-$ $\mathrm{H}]^{-}$; ${ }^{1} \mathrm{H}$ NMR $\left(500 \mathrm{MHz}, \mathrm{CDCl}_{3}\right) \delta 1.55(\mathrm{td}, J=13.6,6.6 \mathrm{~Hz}, 1 \mathrm{H})$, $1.90-2.10(\mathrm{~m}, 2 \mathrm{H}), 2.20-2.33(\mathrm{~m}, 1 \mathrm{H}), 2.64(\mathrm{dd}, J=13.1,5.8 \mathrm{~Hz}, 1$ $\mathrm{H}), 3.03(\mathrm{dd}, J=14.0,5.5 \mathrm{~Hz}, 1 \mathrm{H}), 3.35(\mathrm{~s}, 3 \mathrm{H}), 3.77(\mathrm{~s}, 3 \mathrm{H}), 4.13$ $(\mathrm{s}, 3 \mathrm{H}), 5.19$ (d, $J=15.4 \mathrm{~Hz}, 1 \mathrm{H}), 5.39(\mathrm{~d}, J=15.4 \mathrm{~Hz}, 1 \mathrm{H}), 6.26(\mathrm{~s}$, $1 \mathrm{H}), 6.33(\mathrm{~d}, J=8.2 \mathrm{~Hz}, 1 \mathrm{H}), 6.66(\mathrm{~d}, J=8.2 \mathrm{~Hz}, 1 \mathrm{H}), 7.20(\mathrm{~s}, 2 \mathrm{H})$, $7.56(\mathrm{~s}, 1 \mathrm{H}), 9.90(\mathrm{~s}, 1 \mathrm{H}), 13.97(\mathrm{~s}, 1 \mathrm{H}), 15.93(\mathrm{~s}, 1 \mathrm{H})$.

Ethyl 3-(4-(Allyloxy)-3-bromophenyl)-2-azidoacrylate (28). To a solution of 3-bromo-4-hydroxybenzaldehyde $(10.0 \mathrm{~g}, 50 \mathrm{mmol})$ in DMF $(50 \mathrm{~mL})$ were added $\mathrm{K}_{2} \mathrm{CO}_{3}(7.6 \mathrm{~g}, 55 \mathrm{mmol})$ and allyl bromide $(4.5 \mathrm{~mL}, 52.5 \mathrm{mmol})$. The reaction mixture was stirred at room temperature for $16 \mathrm{~h}$. The reaction mixture was then poured into
$\mathrm{H}_{2} \mathrm{O}(100 \mathrm{~mL})$ and extracted with $\mathrm{Et}_{2} \mathrm{O}(100 \mathrm{~mL} \times 2)$. The combined organic extracts were washed with brine, dried over $\mathrm{MgSO}_{4}$, filtered, and concentrated to afford 4-(allyloxy)-3-bromobenzaldehyde (11.2 g, 93\%) as a clear oil (LC-MS $\left.m / z=243.1[\mathrm{M}+\mathrm{H}]^{+}\right)$, which was used directly in the next step. To a solution of 4-(allyloxy)-3bromobenzaldehyde (11.2 g, $46.5 \mathrm{mmol})$ and ethyl 2-azidoacetate $(19.0 \mathrm{~g}, 140 \mathrm{mmol})$ in EtOH $(100 \mathrm{~mL})$, cooled to $-10{ }^{\circ} \mathrm{C}$, was added NaOEt $(50 \mathrm{~mL}, 2.76 \mathrm{M})$ dropwise over $20 \mathrm{~min}$. The reaction mixture was then warmed to $5{ }^{\circ} \mathrm{C}$ and stirred for $16 \mathrm{~h}$ at which point the reaction mixture was cooled to $0{ }^{\circ} \mathrm{C}$ and $\mathrm{H}_{2} \mathrm{O}$ was added. The precipitate was then filtered and washed with $\mathrm{H}_{2} \mathrm{O}$ to provide 28 (10.1 g, $62 \%)$ as a beige powder. ${ }^{1} \mathrm{H}$ NMR $\left(500 \mathrm{MHz}\right.$, DMSO- $\left.d_{6}\right) \delta 1.29-$ $1.35(\mathrm{~m}, 3 \mathrm{H}), 4.31(\mathrm{q}, J=7.09 \mathrm{~Hz}, 2 \mathrm{H}), 4.62(\mathrm{~s}, 2 \mathrm{H}), 5.32(\mathrm{dq}, J=$ $10.60,1.62 \mathrm{~Hz}, 1 \mathrm{H}), 5.52(\mathrm{dq}, J=17.26,1.79 \mathrm{~Hz}, 1 \mathrm{H}), 6.10(\mathrm{ddt}, J=$ $17.25,10.61,4.83,4.83 \mathrm{~Hz}, 1 \mathrm{H}), 7.15(\mathrm{~d}, J=8.75 \mathrm{~Hz}, 1 \mathrm{H}), 7.78-$ 7.90 (m, $2 \mathrm{H}), 8.15-8.22(\mathrm{~m}, 1 \mathrm{H})$.

Ethyl 6-(Allyloxy)-5-bromo-1 $\mathrm{H}$-indole-2-carboxylate (29). A solution of $28(6.5 \mathrm{~g}, 19 \mathrm{mmol})$ in xylenes $(40 \mathrm{~mL})$ was heated to 140 ${ }^{\circ} \mathrm{C}$ for $1 \mathrm{~h}$. The solution was then cooled to room temperature and concentrated. The residue was purified on silica gel (EtOAc/hexanes, $1: 1)$ to afford $29(3.0 \mathrm{~g}, 47 \%)$ as light yellow solid. LC-MS $\mathrm{m} / \mathrm{z}=$ $326.1[\mathrm{M}+\mathrm{H}]^{+}$; ${ }^{1} \mathrm{H}$ NMR (500 MHz, DMSO- $\left.d_{6}\right) \delta 1.33(\mathrm{t}, J=7.09$ $\mathrm{Hz}, 3 \mathrm{H}), 4.33(\mathrm{q}, J=7.15 \mathrm{~Hz}, 2 \mathrm{H}), 4.66(\mathrm{dt}, J=4.79,1.59 \mathrm{~Hz}, 2 \mathrm{H})$, $5.32(\mathrm{dq}, J=10.60,1.62 \mathrm{~Hz}, 1 \mathrm{H}), 5.52(\mathrm{dq}, J=17.26,1.79 \mathrm{~Hz}, 1 \mathrm{H})$, 6.10 (ddt, $J=17.25,10.61,4.83,4.83 \mathrm{~Hz}, 1 \mathrm{H}), 7.01(\mathrm{~s}, 1 \mathrm{H}), 7.07$ (d, $J=1.02 \mathrm{~Hz}, 1 \mathrm{H}), 7.91(\mathrm{~s}, 1 \mathrm{H}), 11.88(\mathrm{~s}, 1 \mathrm{H})$.

Ethyl 6-(Allyloxy)-5-bromo-1-methyl- $1 \mathrm{H}$-indole-2-carboxylate (30). To a solution of $29(5.5 \mathrm{~g}, 16.9 \mathrm{mmol})$ in DMF (17 $\mathrm{mL}$ ), cooled to $0{ }^{\circ} \mathrm{C}$, was added $\mathrm{NaH}(60 \%$ oil dispersion, $0.75 \mathrm{~g}, 18.6$ $\mathrm{mmol})$. Gas evolution was observed, and the mixture was stirred for 30 min at which point $\mathrm{MeI}(1.2 \mathrm{~mL}, 18.6 \mathrm{mmol})$ was added, and the solution was warmed to room temperature. After stirring for $1 \mathrm{~h}$, saturated $\mathrm{NH}_{4} \mathrm{Cl}$ was added, and the mixture was poured into $\mathrm{H}_{2} \mathrm{O}$ and extracted with $\mathrm{Et}_{2} \mathrm{O}$. The organic extracts were washed with brine, dried over $\mathrm{MgSO}_{4}$, filtered, and concentrated to give 30 (5.24 g, 92\%) as a white solid. LC-MS $m / z=340.1[\mathrm{M}+\mathrm{H}]^{+} ;{ }^{1} \mathrm{H}$ NMR $(500 \mathrm{MHz}$, $\left.\mathrm{CDCl}_{3}\right) \delta 1.31(\mathrm{t}, J=7.13 \mathrm{~Hz}, 3 \mathrm{H}), 3.86-3.91(\mathrm{~m}, 3 \mathrm{H}), 4.26(\mathrm{q}, J=$ $7.17 \mathrm{~Hz}, 2 \mathrm{H}), 4.55(\mathrm{dt}, J=4.95,1.59 \mathrm{~Hz}, 2 \mathrm{H}), 5.25(\mathrm{dq}, J=10.63$, $1.47 \mathrm{~Hz}, 1 \mathrm{H}), 5.46(\mathrm{dq}, J=17.26,1.66 \mathrm{~Hz}, 1 \mathrm{H}), 5.97-6.08(\mathrm{~m}, 1 \mathrm{H})$, $6.63(\mathrm{~s}, 1 \mathrm{H}), 7.05(\mathrm{~d}, J=0.79 \mathrm{~Hz}, 1 \mathrm{H}), 7.71(\mathrm{~s}, 1 \mathrm{H})$.

(6-(Allyloxy)-5-bromo-1-methyl- $1 \mathrm{H}$-indol-2-yl)methanol (31). To a solution of $30(5.24 \mathrm{~g}, 15.4 \mathrm{mmol})$ in $\mathrm{CH}_{2} \mathrm{Cl}_{2}(40 \mathrm{~mL})$, cooled to $-78{ }^{\circ} \mathrm{C}$, was added DIBAL-H $(32.4 \mathrm{~mL}, 1 \mathrm{M})$. After stirring at $-78{ }^{\circ} \mathrm{C}$ for $30 \mathrm{~min}$, the reaction was warmed to $0{ }^{\circ} \mathrm{C}$, and $\mathrm{a}$ saturated solution of Rochelle salt $(30 \mathrm{~mL})$ was added followed by $\mathrm{CH}_{2} \mathrm{Cl}_{2}(100 \mathrm{~mL})$. The solution was then warmed to room temperature and stirred for $1 \mathrm{~h}$. The organic layer was separated and washed with brine, dried over $\mathrm{Na}_{2} \mathrm{SO}_{4}$, filtered, and concentrated to afford $31(4.0 \mathrm{~g}, 87 \%)$ as a white solid. LC-MS $m / z=298.0[\mathrm{M}+$ $\mathrm{H}]^{+} ;{ }^{1} \mathrm{H}$ NMR $\left(500 \mathrm{MHz}, \mathrm{CDCl}_{3}\right) \delta 3.66(\mathrm{~s}, 3 \mathrm{H}), 4.60(\mathrm{dt}, J=5.04$ $1.62 \mathrm{~Hz}, 2 \mathrm{H}), 4.73(\mathrm{~s}, 2 \mathrm{H}), 5.27(\mathrm{dd}, J=10.56,1.50 \mathrm{~Hz}, 1 \mathrm{H}), 5.49$ $(\mathrm{dd}, J=17.22,1.62 \mathrm{~Hz}, 1 \mathrm{H}), 6.04-6.14(\mathrm{~m}, 1 \mathrm{H}), 6.20(\mathrm{~d}, J=0.63$ $\mathrm{Hz}, 1 \mathrm{H}), 6.74(\mathrm{~s}, 1 \mathrm{H}), 7.66(\mathrm{~s}, 1 \mathrm{H})$.

6-(Allyloxy)-2-((tert-butyldimethylsilyloxy)methyl)-1-methyl-1H-indole-5-carbaldehyde (32). To a solution of 31 (4.8 g, 16 $\mathrm{mmol})$ in $\mathrm{CH}_{2} \mathrm{Cl}_{2}(30 \mathrm{~mL})$ were added imidazole $(1.2 \mathrm{~g}, 17 \mathrm{mmol})$ and TBSCl $(2.6 \mathrm{~g}, 17 \mathrm{mmol})$. After stirring for $3 \mathrm{~h}$, the solution was washed with $\mathrm{H}_{2} \mathrm{O}$, brine, dried with $\mathrm{Na}_{2} \mathrm{SO}_{4}$, filtered, and concentrated. The crude residue was purified on silica gel $(20 \%$ EtOAc/hexanes) to afford the TBS protected alcohol (5.58 g, 85\%) as a white solid $\left(\mathrm{LC}-\mathrm{MS} \mathrm{m} / z: 410.2[\mathrm{M}+\mathrm{H}]^{+}\right)$. To a solution of this intermediate $(0.2 \mathrm{~g}, 0.5 \mathrm{mmol})$ in THF $(5 \mathrm{~mL})$, cooled to $-78^{\circ} \mathrm{C}$ was added $n-\mathrm{BuLi}\left(300 \mu \mathrm{L}, 2.5 \mathrm{M}\right.$ solution). After stirring at $-78{ }^{\circ} \mathrm{C}$ for 30 $\min , \mathrm{DMF}(100 \mu \mathrm{L})$ was added, and the solution was warmed to room temperature. After stirring for $30 \mathrm{~min}$, the reaction was quenched with saturated $\mathrm{NH}_{4} \mathrm{Cl}(2 \mathrm{~mL})$ and poured into $\mathrm{H}_{2} \mathrm{O}$. The aqueous layer was extracted with $\mathrm{Et}_{2} \mathrm{O}(20 \mathrm{~mL} \times 2)$, and the combined organic phases were washed with brine, dried with $\mathrm{MgSO}_{4}$, filtered, and concentrated to afford $32(165 \mathrm{mg}, 92 \%)$ as a white solid. LC-MS $m / z=360.2[\mathrm{M}$ $+\mathrm{H}]^{+} ;{ }^{1} \mathrm{H}$ NMR $\left(500 \mathrm{MHz}, \mathrm{CDCl}_{3}\right) \delta-0.03-0.02$ (m, $\left.6 \mathrm{H}\right), 0.80-$ 
$0.85(\mathrm{~m}, 9 \mathrm{H}), 3.67(\mathrm{~s}, 3 \mathrm{H}), 4.63(\mathrm{dt}, J=5.10,1.55 \mathrm{~Hz}, 2 \mathrm{H}), 4.71(\mathrm{~d}$, $J=0.32 \mathrm{~Hz}, 2 \mathrm{H}), 5.28(\mathrm{dd}, J=10.56,1.42 \mathrm{~Hz}, 1 \mathrm{H}), 5.40-5.47(\mathrm{~m}, 1$ H), 6.00-6.15 (m, $1 \mathrm{H}), 6.33(\mathrm{~d}, J=0.55 \mathrm{~Hz}, 1 \mathrm{H}), 6.64(\mathrm{~s}, 1 \mathrm{H}), 8.03$ $(\mathrm{s}, 1 \mathrm{H}), 10.45(\mathrm{~s}, 1 \mathrm{H})$.

1-(6-(Allyloxy)-2-((tert-butyldimethylsilyloxy)methyl)-1methyl-1 $\mathrm{H}$-indol-5-yl)prop-2-en-1-ol (33). To a solution of compound $32(5.2 \mathrm{~g}, 14.6 \mathrm{mmol})$ in THF $(60 \mathrm{~mL})$ cooled to $0{ }^{\circ} \mathrm{C}$ was added vinylmagnesium bromide $(16.0 \mathrm{~mL}, 1 \mathrm{M})$. After stirring at 0 ${ }^{\circ} \mathrm{C}$ for $30 \mathrm{~min}$, the solution was warmed to room temperature and stirred for an additional $30 \mathrm{~min}$ at which point saturated $\mathrm{NH}_{4} \mathrm{Cl}(10$ $\mathrm{mL}$ ) was added. The crude reaction mixture was poured into $\mathrm{H}_{2} \mathrm{O}$ and extracted with $\mathrm{Et}_{2} \mathrm{O}(100 \mathrm{~mL} \times 2)$. The combined organic phases were washed with brine, dried over $\mathrm{MgSO}_{4}$, filtered, and concentrated to afford 33 (5.5 g, 98\%) as a yellow oil, which was used immediately in the subsequent step without further purification. ${ }^{1} \mathrm{H}$ NMR $(500 \mathrm{MHz}$, DMSO-d $\left.d_{6}\right) \delta-0.02-0.03(\mathrm{~m}, 6 \mathrm{H}), 0.80-0.86(\mathrm{~m}, 9 \mathrm{H}), 3.63-3.68$ $(\mathrm{m}, 3 \mathrm{H}), 4.59(\mathrm{dt}, J=4.93,1.60 \mathrm{~Hz}, 2 \mathrm{H}), 4.76(\mathrm{~s}, 2 \mathrm{H}), 4.88-4.94$ $(\mathrm{m}, 1 \mathrm{H}), 5.12(\mathrm{~d}, J=4.81 \mathrm{~Hz}, 1 \mathrm{H}), 5.13-5.19(\mathrm{~m}, 1 \mathrm{H}), 5.22-5.27$ (m, $1 \mathrm{H}), 5.40-5.48(\mathrm{~m}, 1 \mathrm{H}), 5.91-6.01(\mathrm{~m}, 1 \mathrm{H}), 6.04-6.14(\mathrm{~m}, 1$ $\mathrm{H}), 6.26(\mathrm{~s}, 1 \mathrm{H}), 6.94(\mathrm{~s}, 1 \mathrm{H}), 7.43(\mathrm{~s}, 1 \mathrm{H})$.

8-((tert-Butyldimethylsilyloxy)methyl)-9-methyl-5,9-dihydro- $2 \mathrm{H}$-oxepino[3,2-f]indol-5-ol (34). To a solution of compound $33(5.5 \mathrm{~g}, 14.3 \mathrm{mmol})$ in toluene $(200 \mathrm{~mL})$ was added Grubbs second generation catalyst $(350 \mathrm{mg})$, and the reaction mixture was heated at $60{ }^{\circ} \mathrm{C}$ for $3 \mathrm{~h}$. The reaction mixture was then cooled to room temperature and concentrated, and the crude residue was purified on silica gel (20\% EtOAc/hexanes) to provide 34 as a light green solid (2.7 g, 51\%). LC-MS $m / z=342.3\left[\mathrm{M}-\mathrm{H}_{2} \mathrm{O}\right]^{-}$; ${ }^{\mathrm{l}} \mathrm{H}$ NMR (500 MHz, DMSO- $\left.d_{6}\right) \delta-0.03-0.03(\mathrm{~m}, 6 \mathrm{H}), 0.79-0.86(\mathrm{~m}, 9 \mathrm{H}), 3.64$ $(\mathrm{s}, 3 \mathrm{H}), 4.17-4.28(\mathrm{~m}, 1 \mathrm{H}), 4.65-4.74(\mathrm{~m}, 1 \mathrm{H}), 4.76(\mathrm{~s}, 2 \mathrm{H})$, $5.23-5.34(\mathrm{~m}, 1 \mathrm{H}), 5.47(\mathrm{~d}, J=5.60 \mathrm{~Hz}, 1 \mathrm{H}), 5.69-5.80(\mathrm{~m}, 2 \mathrm{H})$, $6.30(\mathrm{~d}, J=0.55 \mathrm{~Hz}, 1 \mathrm{H}), 7.08(\mathrm{~s}, 1 \mathrm{H}), 7.41(\mathrm{~d}, J=0.63 \mathrm{~Hz}, 1 \mathrm{H})$.

8-((tert-Butyldimethylsilyloxy)methyl)-9-methyl-3,4-dihydro- $2 \mathrm{H}$-oxepino[3,2-f]indol-5(9H)-one (35). To a solution of compound $34(2.7 \mathrm{~g}, 7.5 \mathrm{mmol})$ in $\mathrm{CH}_{2} \mathrm{Cl}_{2}(40 \mathrm{~mL})$ was added $\mathrm{MnO}_{2}$ in three batches over $2 \mathrm{~h}(1.5,1.0$, and $1.0 \mathrm{~g})$. The reaction mixture was then filtered through Celite and concentrated to afford the unsaturated ketone intermediate as an orange solid (2.0 g, 75\%). LCMS $m / z=358.8[\mathrm{M}-\mathrm{H}]^{-} ;{ }^{1} \mathrm{H}$ NMR $\left(500 \mathrm{MHz}\right.$, DMSO- $\left.d_{6}\right) \delta$ $-0.02-0.02(\mathrm{~m}, 6 \mathrm{H}), 0.79-0.84(\mathrm{~m}, 9 \mathrm{H}), 3.66(\mathrm{~s}, 3 \mathrm{H}), 4.70(\mathrm{dd}, J=$ $4.26,1.66 \mathrm{~Hz}, 2 \mathrm{H}), 4.76(\mathrm{~s}, 2 \mathrm{H}), 6.21(\mathrm{~d}, J=11.82 \mathrm{~Hz}, 1 \mathrm{H}), 6.45(\mathrm{~d}$, $J=0.63 \mathrm{~Hz}, 1 \mathrm{H}), 6.84(\mathrm{~d}, J=11.82 \mathrm{~Hz}, 1 \mathrm{H}), 7.11(\mathrm{~s}, 1 \mathrm{H}), 7.89(\mathrm{~s}, 1$ $\mathrm{H})$. To a solution of the intermediate $(2.0 \mathrm{~g}, 5.6 \mathrm{mmol})$ in $\mathrm{EtOH}(30$ $\mathrm{mL})$ was added $\mathrm{PtO}_{2}(20 \mathrm{mg})$. The flask was evacuated and hydrogenated under a balloon filled with $\mathrm{H}_{2}$. After stirring at room temperature for $3 \mathrm{~h}$, the reaction mixture was filtered through Celite and concentrated to provide $35(1.9 \mathrm{~g}, 94 \%)$ as a tan solid. LC-MS $m / z=360.8[\mathrm{M}+\mathrm{H}]^{+} ;{ }^{1} \mathrm{H}$ NMR $\left(500 \mathrm{MHz}\right.$, DMSO-d $\left.d_{6}\right) \delta 0.00(\mathrm{~s}, 6$ $\mathrm{H}), 0.81(\mathrm{~s}, 9 \mathrm{H}), 1.92-2.01(\mathrm{~m}, 2 \mathrm{H}), 2.65-2.72(\mathrm{~m}, 2 \mathrm{H}), 3.65(\mathrm{~s}, 3$ $\mathrm{H}), 4.11(\mathrm{t}, J=6.70 \mathrm{~Hz}, 2 \mathrm{H}), 4.76(\mathrm{~s}, 2 \mathrm{H}), 6.43(\mathrm{~d}, J=0.63 \mathrm{~Hz}, 1 \mathrm{H})$, $7.10(\mathrm{~s}, 1 \mathrm{H}), 7.81(\mathrm{~s}, 1 \mathrm{H})$.

Methyl 10-((tert-Butyldimethylsilyl)oxy)methyl)-1-(2,4-dimethoxybenzyl)-4-hydroxy-9-methyl-2-oxo-2,5,6,9-tetrahydro-1 $H$-pyrido $\left[2^{\prime}, 3^{\prime}: 4,5\right]$ oxepino $[3,2-f]$ indole-3-carboxylate (36). Following the two-step procedure used to prepare 13c, compound $35(2.7 \mathrm{~g}, 7.5 \mathrm{mmol})$ gave, after purification on silica gel (EtOAc/hexanes, $0-60 \%$ gradient), $36(2.0 \mathrm{~g}, 43 \%)$ as a yellow foam. LC-MS $m / z 633.2[\mathrm{M}-\mathrm{H}]^{-}$; ${ }^{1} \mathrm{H}$ NMR (500 MHz, DMSO- $\left.d_{6}\right) \delta$ $0.00(\mathrm{~d}, J=0.95 \mathrm{~Hz}, 6 \mathrm{H}), 0.77-0.83(\mathrm{~m}, 9 \mathrm{H}), 1.87-1.96(\mathrm{~m}, 2 \mathrm{H})$, $2.88-2.96(\mathrm{~m}, 1 \mathrm{H}), 3.48(\mathrm{~s}, 3 \mathrm{H}), 3.64(\mathrm{~d}, J=1.89 \mathrm{~Hz}, 6 \mathrm{H}), 3.77(\mathrm{~s}$, $3 \mathrm{H}), 4.21$ (br. s, $2 \mathrm{H}), 4.74(\mathrm{~s}, 2 \mathrm{H}), 4.98-5.07(\mathrm{~m}, 1 \mathrm{H}), 6.24$ (s, 1 $\mathrm{H}), 6.37(\mathrm{~s}, 2 \mathrm{H}), 6.61-6.68(\mathrm{~m}, 1 \mathrm{H}), 7.21(\mathrm{~s}, 1 \mathrm{H}), 7.31-7.40(\mathrm{~m}, 1$ $\mathrm{H}), 13.28-13.36(\mathrm{~m}, 1 \mathrm{H})$.

Methyl 1-(2,4-Dimethoxybenzyl)-4-hydroxy-10-(hydroxymethyl)-9-methyl-2-oxo-2,5,6,9-tetrahydro- $1 \mathrm{H}$-pyrido$\left[2^{\prime}, 3^{\prime}: 4,5\right]$ oxepino[3,2-f]indole-3-carboxylate (37). Following the procedure used to prepare $14 \mathrm{c}$, compound $36(2.0 \mathrm{~g}, 3.15 \mathrm{mmol})$, gave, after purification on silica gel (50-100\% EtOAc/hexanes), 37 $(1.3 \mathrm{~g}, 80 \%)$ as a yellow solid. LC-MS $m / z=521.5[\mathrm{M}+\mathrm{H}]^{+} ;{ }^{1} \mathrm{H}$ NMR $\left(500 \mathrm{MHz}\right.$, DMSO- $\left.d_{6}\right) \delta 1.96-2.07(\mathrm{~m}, 1 \mathrm{H}), 3.03$ (dd, $J=$ 14.50, $3.86 \mathrm{~Hz}, 1 \mathrm{H}), 3.60(\mathrm{~s}, 3 \mathrm{H}), 3.75(\mathrm{~d}, J=1.89 \mathrm{~Hz}, 6 \mathrm{H}), 3.87(\mathrm{~s}$,
$3 \mathrm{H}), 4.26-4.37(\mathrm{~m}, 2 \mathrm{H}), 4.63(\mathrm{~d}, J=3.39 \mathrm{~Hz}, 2 \mathrm{H}), 5.13$ (br. s, $1 \mathrm{H})$, 5.27 (br. s, $1 \mathrm{H}), 6.30(\mathrm{~s}, 1 \mathrm{H}), 6.41-6.52(\mathrm{~m}, 2 \mathrm{H}), 6.75(\mathrm{~d}, J=8.35$ $\mathrm{Hz}, 1 \mathrm{H}), 7.31(\mathrm{~s}, 1 \mathrm{H}), 7.45$ (br. s, $1 \mathrm{H})$.

1-(2,4-Dimethoxybenzyl)-4-hydroxy-10-(hydroxymethyl)-9methyl-2-oxo-2,5,6,9-tetrahydro-1 $H$-pyrido $\left[2^{\prime}, 3^{\prime}: 4,5\right]$ oxepino[3,2-f]indole-3-carboxylic Acid (38). Following the procedure used to prepare $15 \mathrm{c}$, compound $37(1.3 \mathrm{~g}, 2.5 \mathrm{mmol})$ gave $38(1.25 \mathrm{~g}, 98 \%)$ as an off-white solid. LC-MS $m / z=505.1[\mathrm{M}-\mathrm{H}]^{-}$; ${ }^{1} \mathrm{H}$ NMR (500 MHz, DMSO- $\left.d_{6}\right) \delta$ ppm 2.05-2.15 (m, $\left.1 \mathrm{H}\right), 3.06(\mathrm{dd}, J=14.50,3.86$ $\mathrm{Hz}, 1 \mathrm{H}), 3.05-3.05(\mathrm{~m}, 1 \mathrm{H}), 3.56-3.62(\mathrm{~m}, 3 \mathrm{H}), 3.75(\mathrm{~s}, 3 \mathrm{H}), 3.77$ $(\mathrm{s}, 3 \mathrm{H}), 4.31-4.42(\mathrm{~m}, 2 \mathrm{H}), 4.65(\mathrm{~s}, 2 \mathrm{H}), 5.22-5.37(\mathrm{~m}, 2 \mathrm{H}), 6.36$ $(\mathrm{s}, 1 \mathrm{H}), 6.44(\mathrm{dd}, J=8.43,2.29 \mathrm{~Hz}, 1 \mathrm{H}), 6.49(\mathrm{~d}, J=2.21 \mathrm{~Hz}, 1 \mathrm{H})$, $6.79(\mathrm{~d}, J=8.43 \mathrm{~Hz}, 1 \mathrm{H}), 7.36(\mathrm{~s}, 1 \mathrm{H}), 7.58($ br. s, $1 \mathrm{H}), 13.85(\mathrm{~s}, 1$ $\mathrm{H}), 16.00-16.08(\mathrm{~m}, 1 \mathrm{H})$.

1-(2,4-Dimethoxybenzyl)-10-formyl-4-hydroxy-9-methyl-2oxo-2,5,6,9-tetrahydro- $1 H$-pyrido $\left[2^{\prime}, 3^{\prime}: 4,5\right]$ oxepino $[3,2-f]-$ indole-3-carboxylic Acid (39). To a solution of 38 (1.25 g, 2.5 $\mathrm{mmol})$ in $\mathrm{CH}_{2} \mathrm{Cl}_{2}(25 \mathrm{~mL})$ was added $\mathrm{MnO}_{2}$ in three batches over $2 \mathrm{~h}$ $(1.5,1.0$, and $1.0 \mathrm{~g})$. The reaction mixture was then filtered through Celite and concentrated to afford the product as a brown foam $(0.81 \mathrm{~g}$, $64 \%)$, which was used without further purification.

\section{ASSOCIATED CONTENT}

\section{Supporting Information}

The Supporting Information is available free of charge on the ACS Publications website at DOI: 10.1021/acs.jmedchem.8b00114.

Free energy plot supporting Figure 2 in Supplemental Graph 1; experimental details on the synthesis and characterization of intermediates 22a, 22b, 22d, 23a, 23d, 24a, 24b, 24d, 25a, 24b, 24d, 25a, 25b, 25d, 26a, 26b, 26d, 27a, 27b, and $27 \mathrm{~d}$ and final targets $4 \mathrm{a}, 5 \mathrm{a}, 6 \mathrm{~d}$, 6e, 6g, 6h, 6k-m, 6t, 6u, 6x, 6y, 7a, 8a, and 8b; LC-MS traces for compounds tested in efficacy studies listed in Table 7; enzymatic data for selected compounds from Tables 6 and 7 in Supplemental Table 1; in vitro antibacterial activity of reference antibiotics in Supplemental Table 2; time-kill kinetic plots for ciprofloxacin against E. coli ${ }^{\mathrm{WT}}$ and $A$. baumannii ${ }^{\mathrm{WT}}$ in Supplemental Figure 1; biological study protocols; in vivo study protocols (PDF)

Molecular formula strings for compounds $\mathbf{2} \mathbf{a}-\mathbf{8 b}$ (CSV)

\section{AUTHOR INFORMATION}

\section{Corresponding Author}

*E-mail: marnold@ptcbio.com. Phone: 908-912-9125.

ORCID

Michael A. Arnold: 0000-0002-2560-9360

Notes

The authors declare no competing financial interest.

\section{ACKNOWLEDGMENTS}

The authors wish to thank Dr. Lynn Zechiedrich of Baylor College of Medicine, Houston, TX for providing fluoroquinolone resistant E. coli strains and Micromyx, LLC of Kalamazoo, MI for providing multidrug resistant A. baumannii strains as well as Micromyx, LLC for conducting susceptibility testing. This project had been funded in part by the Wellcome Trust through a Seeding Drug Discovery award (097753).

\section{ABBREVIATIONS USED}

DIBAL-H, diisobutylaluminum hydride; DMB, dimethyoxybenzyl; TBS, tert-butyldimethylsilyl; TPAP, tetra- $n$-propylammonium perruthenate; $\mathrm{NMO}, \mathrm{N}$-methylmorpholine- $\mathrm{N}$-oxide; $F$, 
oral bioavailability; $f_{\mathrm{w}}$ fraction unbound; ip, intraperitoneally; iv, intravenous; GyrA, A-subunit of DNA gyrase; parC, gene that encodes for the C-subunit of topoisomerase IV; QRDR, quinolone resistance-determining region

\section{REFERENCES}

(1) (a) Bush, K.; Courvalin, P.; Dantas, G.; Davies, J.; Eisenstein, B.; Huovinen, P.; Jacoby, G. A.; Kishony, R.; Kreiswirth, B. N.; Kutter, E.; Lerner, S. A.; Levy, S.; Lewis, K.; Lomovskaya, O.; Miller, J. H.; Mobashery, S.; Piddock, L. J. V.; Projan, S.; Thomas, C. M.; Tomasz, A.; Tulkens, P. M.; Walsh, T. R.; Watson, J. D.; Witkowski, J.; Witte, W.; Wright, G.; Yeh, P.; Zgurskaya, H. I. Tackling antibiotic resistance. Nat. Rev. Microbiol. 2011, 9, 894-896. (b) Ventola, C. L. The antibiotic resistance crisis. Pharmacy and Therapeutics 2015, 40, 277283.

(2) Centers for Disease Control and Prevention. Antibiotic resistance threats in the United States. US Department of Health and Human Services: Atlanta, GA, 2013. Available from http://www.cdc.gov/ drugresistance/pdf/ar-threats-2013-508.pdf (accessed March 28, 2018).

(3) (a) Smith, R; Coast, J. The true cost of antimicrobial resistance. BMJ. 2013, 346, f1493. (b) World Health Organization. Antimicrobial Resistance: Global Report on Surveillance 2014; WHO: Geneva, Switzerland, 2014. Available from http://apps.who.int/iris/bitstream/ 10665/112642/1/9789241564748_eng.pdf (accessed March 28, 2018).

(4) Boucher, H. E.; Talbot, G. H.; Benjamin, D. K., Jr.; Bradley, J.; Guidos, R. J.; Jones, R. N.; Murray, B. E.; Bonomo, R. A.; Gilbert, D. 10 x '20 Progress-development of new drugs active against Gramnegative bacilli: An update from the Infectious Diseases Society of America. Clin. Infect. Dis. 2013, 56, 1685-1694.

(5) Rex, J. H. ND4BB: Addressing the antimicrobial resistance crisis. Nat. Rev. Microbiol. 2014, 12, 231-232.

(6) (a) Singh, S. B. Confronting the challenges of discovery of novel antibacterial agents. Bioorg. Med. Chem. Lett. 2014, 24, 3683-3689. (b) Page, M. G. P.; Kellenberger, L. Stemming the tide? Advances in antibiotic discovery and development in the face of emerging resistance and financial constraint. Curr. Opin. Pharmacol. 2012, 12, 519-521. (c) Silver, L. L. Challenges of antibacterial discovery. Clin. Microbiol. Rev. 2011, 24, 71-109. (d) Shlaes, D. M.; Spellberg, B. Overcoming the challenges to developing new antibiotics. Curr. Opin. Pharmacol. 2012, 12, 522-526.

(7) (a) Kinch, M. S.; Patridge, E.; Plummer, M.; Hoyer, D. An analysis of FDA-approved drugs for infectious disease: Antibacterial agents. Drug Discovery Today 2014, 19, 1283-1287. (b) Butler, M. S.; Blaskovich, M. A. T.; Cooper, M. A. Antibiotics in the clinical pipeline at the end of 2015. J. Antibiot. 2017, 70, 3-24.

(8) (a) Andriole, V. T. The quinolones: Past, present, and future. Clin. Infect. Dis. 2005, 41, S113-119. (b) Appelbaum, P. C.; Hunter, P. A. The fluoroquinolone antibacterials: Past, present and future perspectives. Int. J. Antimicrob. Agents 2000, 16, 5-15. (c) Aldred, K. J.; Kerns, R. J.; Osheroff, N. Mechanism of quinolone action and resistance. Biochemistry 2014, 53, 1565-1574. (d) Tomasic, T.; Masic, L. P. Prospects for developing new antibacterials targeting bacterial Type IIA topoisomerases. Curr. Top. Med. Chem. 2014, 14, 130-151. (e) Mitscher, L. A. Bacterial topoisomerase inhibitors: Quinolone and pyridone antibacterial agents. Chem. Rev. 2005, 105, 559-592.

(9) Khodursky, A. B.; Zechiedrich, E. L.; Cozzarelli, N. R. Topoisomerase IV is a target of quinolones in Escherichia coli. Proc. Natl. Acad. Sci. U. S. A. 1995, 92, 11801-11805.

(10) Ellsworth, E. L.; Tran, T. P.; Showalter, H. D. H.; Sanchez, J. P.; Watson, B. M.; Stier, M. A.; Domagala, J. M.; Gracheck, S. J.; Joannides, E. T.; Shapiro, M. A.; Dunham, S. A.; Hanna, D. L.; Huband, M. D.; Gage, J. W.; Bronstein, J. C.; Liu, J. Y.; Nguyen, D. Q.; Singh, R. 3-Aminoquinazolinediones as a new class of antibacterial agents demonstrating excellent antibacterial activity against wild-type and multidrug resistant organisms. J. Med. Chem. 2006, 49, 64356438.
(11) (a) Li, Q.; Chu, D. T. W.; Claiborne, A.; Cooper, C. S.; Lee, C. M.; Raye, K.; Berst, K. B.; Donner, P.; Wang, W.; Hasvold, L.; Fung, A.; Ma, Z.; Tufano, M.; Flamm, R.; Shen, L. L.; Baranowski, J.; Nilius, A.; Alder, J.; Meulbroek, J.; Marsh, K.; Crowell, D.; Hui, Y.; Seif, L.; Melcher, L. M.; Henry, R.; Spanton, S.; Faghih, R.; Klein, L. L.; Tanaka, S. K.; Plattner, J. J. Synthesis and structure-activity relationships of 2-pyridones: A novel series of potent DNA gyrase inhibitors as antibacterial agents. J. Med. Chem. 1996, 39, 3070-3088. (b) Ma, Z.; Chu, D. T. W.; Cooper, C. S.; Li, Q.; Fung, A. K. L.; Wang, S.; Shen, L. L.; Flamm, R. K.; Nilius, A. M.; Alder, J. D.; Meulbroek, J. A.; Or, Y. S. Synthesis and antimicrobial activity of 4H-4oxoquinolizine derivatives: Consequences of structural modification at the C-8 position. J. Med. Chem. 1999, 42, 4202-4213. (c) Li, Q.; Mitscher, L. A.; Shen, L. L. The 2-pyridone antibacterial agents: Bacterial topoisomerase inhibitors. Med. Res. Rev. 2000, 20, 231-293.

(12) (a) Pucci, M. J.; Podos, S. D.; Thanassi, J. A.; Leggio, M. J.; Bradbury, B. J.; Deshpande, M. In vitro and in vivo profiles of ACH702, an isothiazoloquinolone, against bacterial pathogens. Antimicrob. Agents Chemother. 2011, 55, 2860-2871. (b) Wiles, J. A.; Hashimoto, A.; Thanassi, J. A.; Cheng, J.; Incarvito, C. D.; Deshpande, M.; Pucci, M. J.; Bradbury, B. J. Isothiazolopyridones: Synthesis, structure, and biological activity of a new class of antibacterial agents. J. Med. Chem. 2006, 49, 39-42. (c) Cooper, I. R.; McCarroll, A. J.; McGarry, D.; Kirkham, J.; Pichowicz, M.; Walker, R.; Warrilow, C.; Salisbury, A.-M.; Savage, V. J.; Moyo, E.; Forward, H.; Cheung, J.; Metzger, R.; Gault, Z.; Nelson, G.; Hughes, D.; Cao, S.; Maclean, J.; Charrier, C.; Craighead, M.; Best, S.; Stokes, N. R.; Ratcliffe, A. J. Discovery and structure-activity relationships of a novel isothiazolone class of bacterial Type II topoisomerase inhibitors. Bioorg. Med. Chem. Lett. 2016, 26, 4179-4183.

(13) Black, M. T.; Stachyra, T.; Platel, D.; Girard, A.-M.; Claudon, M.; Bruneau, J.-M.; Miossec, C. Mechanism of action of the antibiotic NXL101, a novel nonfluoroquinolone inhibitor of bacterial type II topoisomerases. Antimicrob. Agents Chemother. 2008, 52, 3339-3349.

(14) (a) Basarab, G. S.; Brassil, P.; Doig, P.; Galullo, V.; Haimes, H. B.; Kern, G.; Kutschke, A.; McNulty, J.; Schuck, V. J. A.; Stone, G.; Gowravaram, M. Novel DNA gyrase inhibiting spiropyrimidinetriones with a benzisoxazole scaffold: SAR and in vivo characterization. J. Med. Chem. 2014, 57, 9078-9095. (b) Basarab, G. S.; Doig, P.; Galullo, V.; Kern, G.; Kimzey, A.; Kutschke, A.; Newman, J. P.; Morningstar, M.; Mueller, J.; Otterson, L.; Vishwanathan, K.; Zhou, F.; Gowravaram, M. Discovery of novel DNA gyrase inhibiting spiropyrimidinetriones: Benzisoxazole fusion with $\mathrm{N}$-linked oxazolidinone substituents leading to a clinical candidate (ETX0914). J. Med. Chem. 2015, 58, 62646282. (c) Basarab, G. S.; Kern, G. H.; McNulty, J.; Mueller, J. P.; Lawrence, K.; Vishwanathan, K.; Alm, R. A.; Barvian, K.; Doig, P.; Galullo, V.; Gardner, H.; Gowravaram, M.; Huband, M.; Kimzey, A.; Morningstar, M.; Kutschke, A.; Lahiri, S. D.; Perros, M.; Singh, R.; Schuck, V. J. A.; Tommasi, R.; Walkup, G.; Newman, J. V. Responding to the challenge of untreatable gonorrhea: ETX0914, a first-in-class agent with a distinct mechanism-of-action against bacterial Type II topoisomerases. Sci. Rep. 2015, 5, 11827.

(15) Arnold, M. A.; Gerasyuto, A. I.; Wang, J.; Du, W.; Kim Gorske, Y. J.; Arasu, T.; Baird, J.; Almstead, N. G.; Narasimhan, J.; Peddi, S.; Ginzburg, O.; Lue, S. W.; Hedrick, J.; Sheedy, J.; Lagaud, G.; Branstrom, A. A.; Weetall, M.; Vara Prasad, J. V. N.; Karp, G. M. 4Hydroxy-2-pyridones: Discovery and evaluation of a novel class of antibacterial agents targeting DNA synthesis. Bioorg. Med. Chem. Lett. 2017, 27, 5014-5021.

(16) Choi, S.; Branstrom, A.; Gothe, S. A.; Lipman, R.; Tamilarasu, N.; Wilde, R. Heterocyclic Inhibitors of Bacterial Peptidyl tRNA Hydrolase. WO2008127274, October 23, 2008.

(17) A similar strategy has been employed for the construction of conformationally constrained tetracyclic fluoroquinolones. See Wagman, A. S.; Cirz, R.; McEnroe, G.; Aggen, J.; Linsell, M. S.; Goldblum, A. A.; Lopez, S.; Gomez, M.; Miller, G.; Simons, L. J.; Belliotti, T. R.; Harris, C. R.; Poel, T.; Melnick, M. J.; Gaston, R. D.; Moser, H. E. Synthesis and microbiological evaluation of novel tetracyclic fluoroquinolones. ChemMedChem 2017, 12, 1687-1692. 
(18) Mackman, R. L.; Katz, B. A.; Breitenbucher, J. G.; Hui, H. C.; Verner, E.; Luong, C.; Liu, L.; Sprengeler, P. A. Exploiting subsite S1 of trypsin-like serine proteases for selectivity: Potent and selective inhibitors of urokinase-type plasminogen activator. J. Med. Chem. 2001, 44, 3856-3871.

(19) Larock, R. C.; Yum, E. K.; Refvik, M. D. Synthesis of 2,3disubstituted indoles via palladium-catalyzed annulation of internal alkynes. J. Org. Chem. 1998, 63, 7652-7662.

(20) Molander, G. A.; Brown, A. R. Suzuki-Miyaura cross-coupling reactions of potassium vinyltrifluoroborate with aryl and heteroaryl electrophiles. J. Org. Chem. 2006, 71, 9681-9686.

(21) Vougioukalakis, G. C.; Grubbs, R. H. Ruthenium-based heterocyclic carbene-coordinated olefin metathesis catalysts. Chem. Rev. 2010, 110, 1746-1787.

(22) (a) Scholl, M.; Ding, S.; Lee, C. W.; Grubbs, R. H. Synthesis and activity of a new generation of ruthenium-based olefin metathesis catalysts coordinated with 1,3-dimesityl-4,5-dihydroimidazol-2-ylidene ligands. Org. Lett. 1999, 1, 953-956. (b) Bielawski, C. W.; Grubbs, R. $\mathrm{H}$. Highly efficient ring-opening metathesis polymerization (ROMP) using new ruthenium catalysts containing N-heterocyclic carbene ligands. Angew. Chem., Int. Ed. 2000, 39, 2903-2306.

(23) Gribble, G. W. Recent developments in indole ring synthesis methodology and applications. J. Chem. Soc., Perkin Trans. 1 2000, $1045-1075$.

(24) Sampson, B. A.; Misra, R.; Benson, S. A. Identification and characterization of a new gene of Escherichia coli K-12 involved in outer membrane permeability. Genetics 1989, 122, 491-501.

(25) Morgan-Linnell, S. K.; Zechiedrich, L. Contributions of the combined effects of topoisomerase mutations toward fluoroquinolone resistance in Escherichia coli. Antimicrob. Agents Chemother. 2007, 51, $4205-4208$.

(26) Boyd, L. B.; Maynard, M. J.; Morgan-Linnell, S. K.; Horton, L. B.; Sucgang, R.; Hamill, R. J.; Jimenez, J. R.; Versalovic, J.; Steffen, D.; Zechiedrich, L. Relationships among ciprofloxacin, gatifloxacin, levofloxacin, and norfloxacin MICs for fluoroquinolone-resistant Escherichia coli clinical isolates. Antimicrob. Agents Chemother. 2009, 53, 229-234.

(27) Multi-drug resistant strain A. baumannii MMX2240 was kindly provided by MicroMyx, LLC, Kalamazoo, MI, USA.

(28) Performance Standards for Antimicrobial Susceptibility Testing: Seventeenth International Supplement. M100-S17; Clinical and Laboratory Standards Institute: Wayne, PA, 2011.

(29) (a) Nikaido, H.; Thanassi, D. Penetration of lipophilic agents with multiple protonation sites into bacterial cells: Tetracyclines and fluoroquinolones as examples. Antimicrob. Agents Chemother. 1993, 37, 1393-1399. (b) Masi, M.; Réfregiers, M.; Pos, K. M.; Pagès, J.-M. Mechanisms of envelope permeability and antibiotic influx and efflux in Gram-negative bacteria. Nat. Microbiol. 2017, 2, 17001.

(30) Calculations were performed with B3LYP/6-31G* density functional minimization using PM3 level of theory employing Spartan '10 (2010) software, Wave Function, Inc.

(31) See Supporting Information for detailed experimental protocols. (32) The cyclohepta[1,2-f]indole series is represented by ten distinct basic amines. The other three series are represented by nine. For easier visualization, overlapping data points were separated using the jitter function in Spotfire.

(33) Susceptibility testing was conducted at Micromyx, LLC, Kalamazoo, MI, USA. The compounds were tested in Mueller Hinton II broth, and MIC values were determined using a broth microdilution procedure described by the Clinical and Laboratory Standards Institute. The $12 \mathrm{E}$. coli isolates comprised the following phenotypes: wild-type, strains resistant to either quinolones, $\beta$-lactams, aminoglycosides, or multidrug resistant isolates. The $12 \mathrm{~A}$. baumannii isolates comprised the following phenotypes: wild-type, strains resistant to either aminoglycosides, quinolones, $\beta$-lactams, carbapenems, or multidrug resistant isolates.

(34) Rodvold, K. A.; Neuhauser, M. Pharmacokinetics and pharmacodynamics of fluoroquinolones. Pharmacotherapy 2001, 21, 233S-252S. 